

\title{
AVLIS
}

\section{Industrial Access Program}

\author{
Document PP-020 \\ November 15, 1984
}

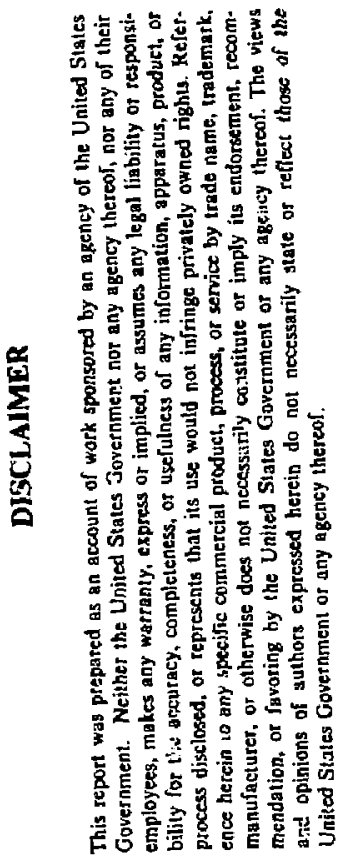

M.L Spaeth. Lastr tso to be Separation

Deputy Frogram Leader

Lawrence Livermore National Labontory

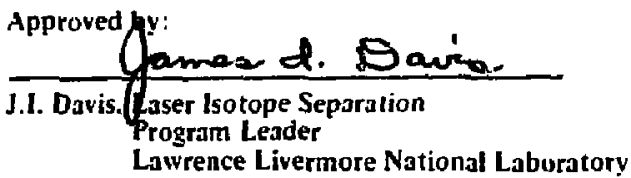

\section{LAWRENCE LIVERMORE NATIONAL LABORATORY}

University of California - Livermore, California - 94550

MARTIN MARIETTA ENEKGY SYSTEMS. INC,

Oak Ridge. Tennessee, 37831

\section{MARTIN MAATERTA}

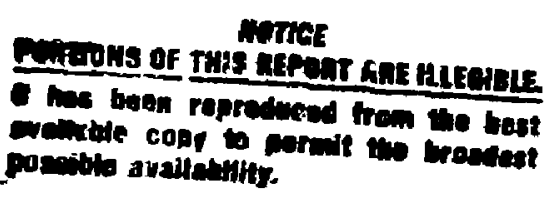

$$
i / i i
$$


1. Executive Summary............................................ I

1.1. Introduction.......................................... 1

1.2. Purpose of the Industria] Access Program..................... 2

1.5. Goals of the Industrial Access Program..................... 3

1.3.1. Develop Relijble Supplier and Support Network........... 3

1.3.2. Promote Effective Use of Industrial Capability........... 3

1.3.3. Spin-off AVLIS Technology........................ 5

1.3.4. ULilize Small Business and Government Socio-Economic

Guidel ines...................................... 5

1.4. Project Description.................................... 5

1.4.1. Introduction................................... 5

1.4.2. Physical Description............................. 6

1.4.3. Schedule.......................................... 7

1.4.4. Costs.......................................... 7

1.5. General Procurement Discussion........................... 10

1.5 .1 . Scope........................................ 10

1.5 .2 . Strategy........................................ 10

1.5.3. Oata Base...................................... 11

1.5.4. Action Plan..................................... 11

2. Procurement Strategy....................................... 13

2.1. Background......................................... 13

2.1.1. Program Description............................... 13

2.1.2. Process and Equipment Description................... 13

2.1.3. Nature of Procurements............................. 19

2.1.4. Procurement Types................................ 20

2.2. 0iscussion.......................................... 23

2.2.1. Procurement Guidelines............................ 23

2.2.2. Procurement Methods............................... 33

2.2.3. Quality Assurance............................... 37 
3. Procurement and Supplier Data Base........................ 38

3.1. Introduction....................................... 38

3.2. Commercial Availability of AVLIS Equipment............... 38

3.3. Supplier List...................................... 42

3.4. AVLIS Production Plant Project Cost Breakdowns.............. 46

3.4.1. Cost Breakdown by Work Breakdown Structure........... 46

3.4.2. Cost Breakdown by Procurement Category...............47

3.5. Schedule........................................ 47

3.6. Developmental Materials/Equipment List................... 49

4. Action Plan........................................... 56

4.1. Potential Supplier Identification Activities.............. 56

4.2. Action Items for Pracurements Requiring Special Attention....... 57

4.2.1. Long Lead Items................................ 57

4.2.2. Developmental Materials/Equipment.................. 57

4.2.3. Vendor Access to Classified Technology................ 58

4.3. Technology Transfer Activities........................ 58

4.3.1. Improvements in Existing Technology................ 58

1.3.2. Other Applications of Separator/Laser Technology........ 58

4.3.3. Industrial Photo-Chemical Processing................. 59

4.3.4. Application of Laser Isotope Separation in Other Areas... 59

4.3.5. Privatization.............................. 60

Appendix A: Industrial Access Program Supplier List ..............61

Appendix B: Developmental Materials/Equipment................97 
The AVLIS Industrial Access Program general7y covers AVLIS procurement plans from the present through plant operations for $E$ ither a Federal or a private enrichment enterprise. The material presented in this document is tailored to the requirements for Data Package III of the 1985 Federal selection process. For this purpose, the concentration is on the federal enterprise and construction of the first plant. Privatization is not discussed.

Developmental procurements for the engineering demonstration phase are discussed; no developmental procurements are planned for the plant. The levels of integration at which procurements will be made are presented; the procurement decisions for the first plant will be made on the bas is of cost. Long-term procurement plans conditioned by a maturing comercialization of the equipment are discussed in policy, but not in detail. In general, AVLIS will be proactive in ensuring and promoting comercial access to the technology; the benefit being decreased costs to the enterprise and spin-off markets for AVLIS suppliers. 


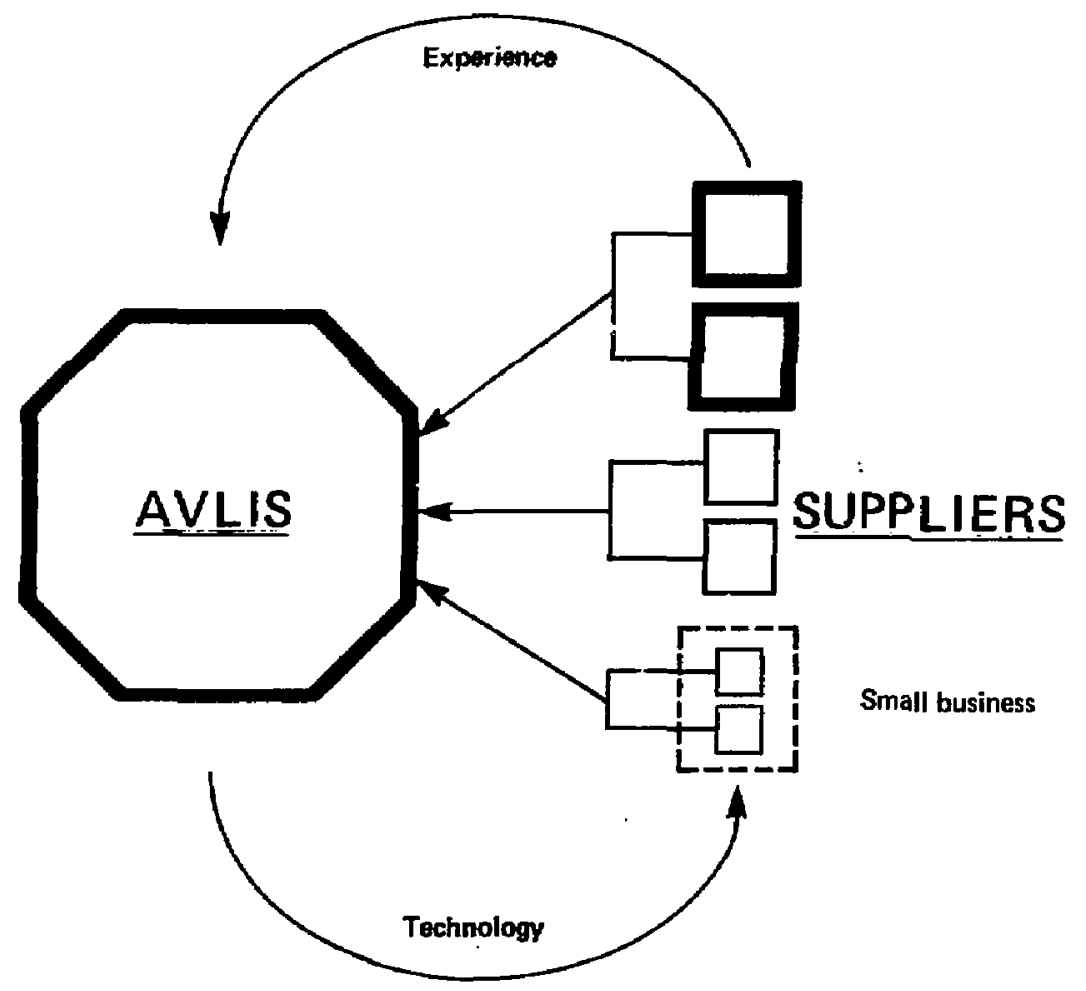

AVLIS benefits from industrial experience and capability through its procurements and encourages AVLIS suppliers to utilize its advances in technology. The build-to-print nature of many AYLIS procurements permits significant small business participation. 
This document provides an overview of the AVL IS technology development and facility construction phases. A key feature of this program is continued work in cooperation with the AVLIS suppliers to improve the performance of facility equipment. This continuing effort is helping industry enhace its existing capabilities while achieving the primary AVLIS performance and deployment goals.

\subsection{GOALS OF THE INDUSTRIAL ACCESS PROGRAM}

\subsubsection{Cevelop a Reliable Supplier and Support Network}

The construction of the AVLIS Production Plant will require several types of industrial partners, in addition to equipment suppliers. Systems and facility engineering will be provided by engineering companies with close support from LLNL and Martin Marietta Energy Systems. The organization and responsibilities of these support companies will be determined by the project plan and schedule that is selected for the construction of the production piant. The existing organization composed of LLNL and Martin Marietta Energy Systems, with engineering and construction companies, has demonstrated that this approach can work effectively.

\subsubsection{Pronite Effective Use of Industrial Capability}

The suppliers to the AVLIS progran come from all parts of the United States. Figure 1-1 shows the locations of the AVLIS suppliers from the last two year period. Effective utilization of the technical and commercial experience of these suppliers will minimize the cost and time required to build the AVLIS Production Plant and facilitate its smooth operation. 


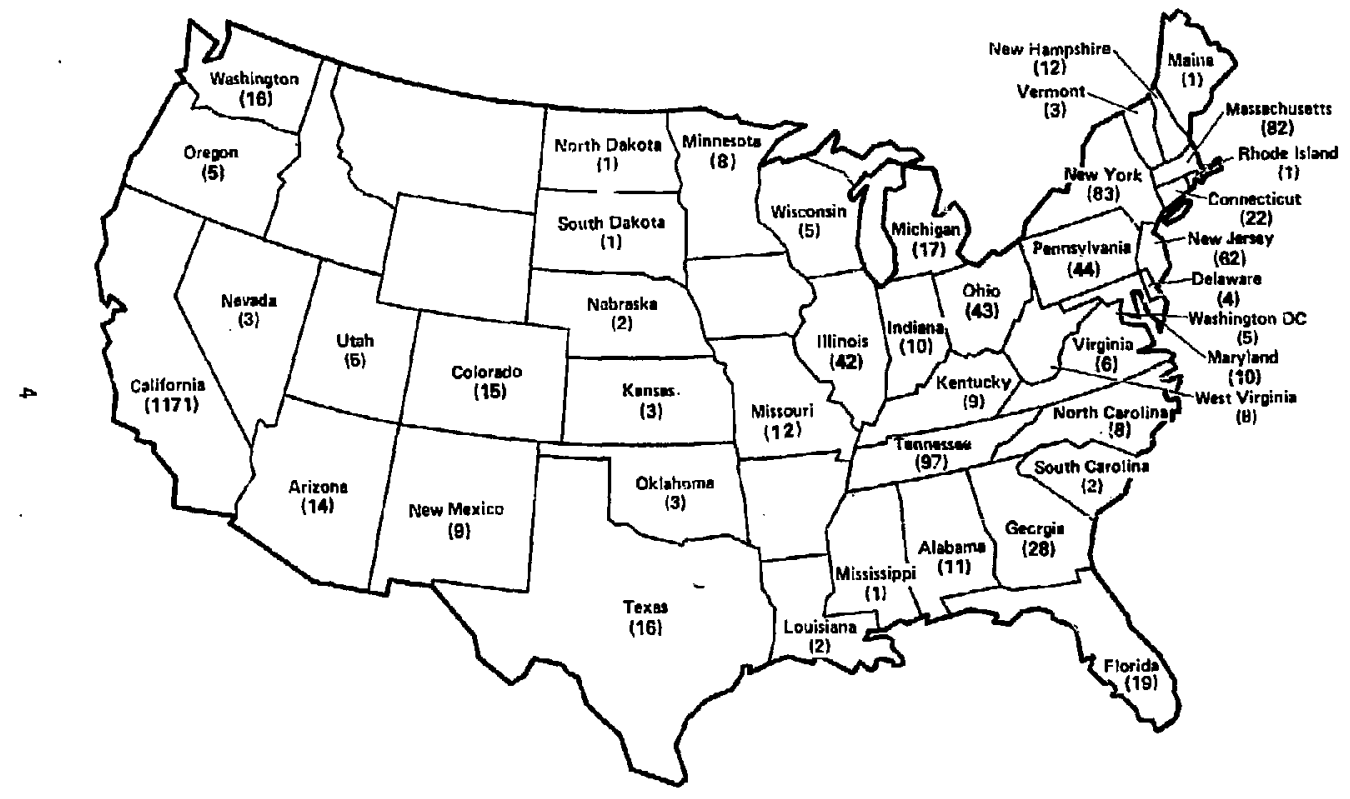

Fig. 1-1. This map illustrates the AVLIS suppiier network for the past two years. The numbers shown for each state represents the suppliers that provided equipment and services for both the tivermore, Calif. and gak Ridge, Tenn. sites. 


\subsubsection{Spin-0ff AVLIS Jechnology}

Although transfer of technology is not required to support the construction of the AVLIS Production Plant, the new technology developed for the AVLIS process, in general, will be made available to industry. The Industrial Access Program facilitates the program/industry interactions needed to support this spin-off of technology. There will be constraints on the transfer of some of the technology because of classification restrictions. However, the advances that will be shared will allow the suppliers to establish markets, beyond AVLIS, for new products and services.

Private industry will benefit from the government-funded AVLIS development program in a number of areas. Some of the advances derived froin AVLIS that will be ready for commercial use are in copper vapor and dye laser components and systens, remote optical monitoring and process control, liquid metal handling, photochemical processes, and military app] ications.

The AVLIS program will benef it from the development of expanded markets for AVLIS suppliers. The cost of products supplied to the AVLIS program will be further reduced because of the economy of scale achieved by jts suppliers.

\subsubsection{Utilize Small Business and Government Socio-Economic Guidel ines}

The AVLIS organization utilizes the procurement guidelines that are specified by the Federal government. The AVLIS program gives special emphas is to the utilization of small businesses. There are many AVLIS procurement needs, both in conventional and advanced technology areas, that small businesses are well-suited to supply. The AVLIS program, via the Industrial Access Program, ensures that the benefits of AVLIS technology are equitably and effectively distributed.

\subsection{PROJECT DESCRIPTION}

\subsubsection{Introduction}

The first AVLIS Production Plant is planned to be built in two increments--the initial increment and the fully activated plant. This 
strategy will allow rapid deployment and early displacement of the existing gaseous diffusion enrichment plants. The initidi increment of production for the first p?ant will be 5 million separative work units per year. The production capacity of the fully activated plant, which will incorporate technological advances currently in development, will be $10-13$ million separative work units per year.

\subsubsection{Phys icai Description}

The first AVLIS Production PTant will be built at the K-25 site in Oak Ridge, Tenn., or at another of the Demartment of Energy's gaseous diffusion plant sites. The production plant will consist of a process building, feed and product handling builidings, and various support operations buildings. Because of the lacation of the Plant on an existing enrichment facility site, many of the facilities are already in place. An AVLIS Production Plani built at a new site will require additional basic facilities.

The process building is the core of the AVLIS Production Plant. This building contains laser systems, separator systems, laser and separator refurbishment areas, instrumentation and controls, and areas for other general process support. The total area of this process building will be approximately $560000 \mathrm{ft}^{2}$. This area will be sufficient to house $\mathrm{all}$ equipinent required for the fully activated plant, as well as the initial production increment.

The other structures that will make up the AVLIS Production Plant are the separator mechanical equipment building, the laser mechanical equipinent building, the separator utility building, the dye purnp building, the diesel generator building, the motor generator storage building, the $F_{2}$ generation building, the $U F_{6}$ feed building, the feed preparation building, the feed conversion building, the uranium recovery building, the product conversion building, a general office/changing-room/control room building, and the administration building. The projected total size of the production plant site is 
80 acres. Figure 1.2 contains a sketch of the the AVLIS Production Plant as it is planned for the $K-25$ site in Oak Ridge.

\subsubsection{Schedule}

The AVLIS program strategy is to deploy the initial increment of production as soon as reasonably possible. A project deployment schedule corresponding to this strategy is shown in Fig. 1-3.

The deployment strategy for the AVLIS Production Plant initial increment calls for site construction to begin twelve manths after the engineering start (October 1985) with a 57-month overall construccion and activation duration to the end of FY91. The procurement of long-lead items will begin in 1987, with all construction-, and startup-related procurements complete in mid-1990. Operation of the production plant will begin in early 1990, 'with the full capacity of 5 MSwll per year achievad in 1991. The conventional facilities will be completed by late 1988 to permit the installation of special equipment/systems.

\subsubsection{Costs}

The overall cost of the initial increment of the AVLIS Production Plant is estimated to be less than 1 billion dollars. This amount consists of approximately $37 \%$ for facilities and $63 \%$ for equipment and process support systems. Facilities covers site preparation, landscaping, utilities, buildings, and building systems. A general procurement category breakdown of the initial increment of the AVLIS Production Piant is shown below:

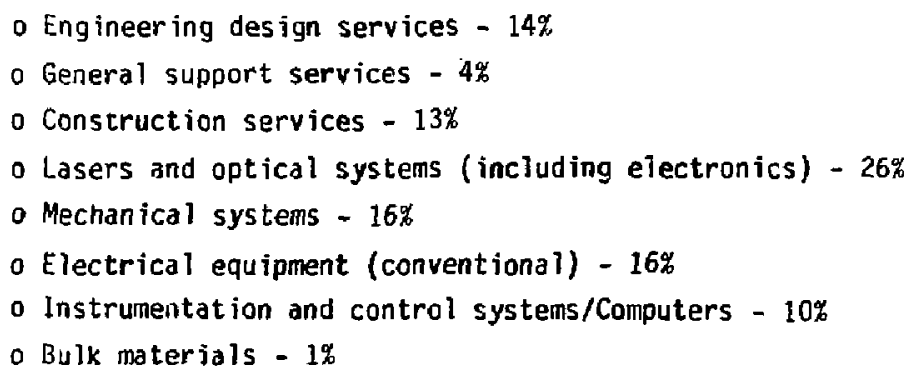




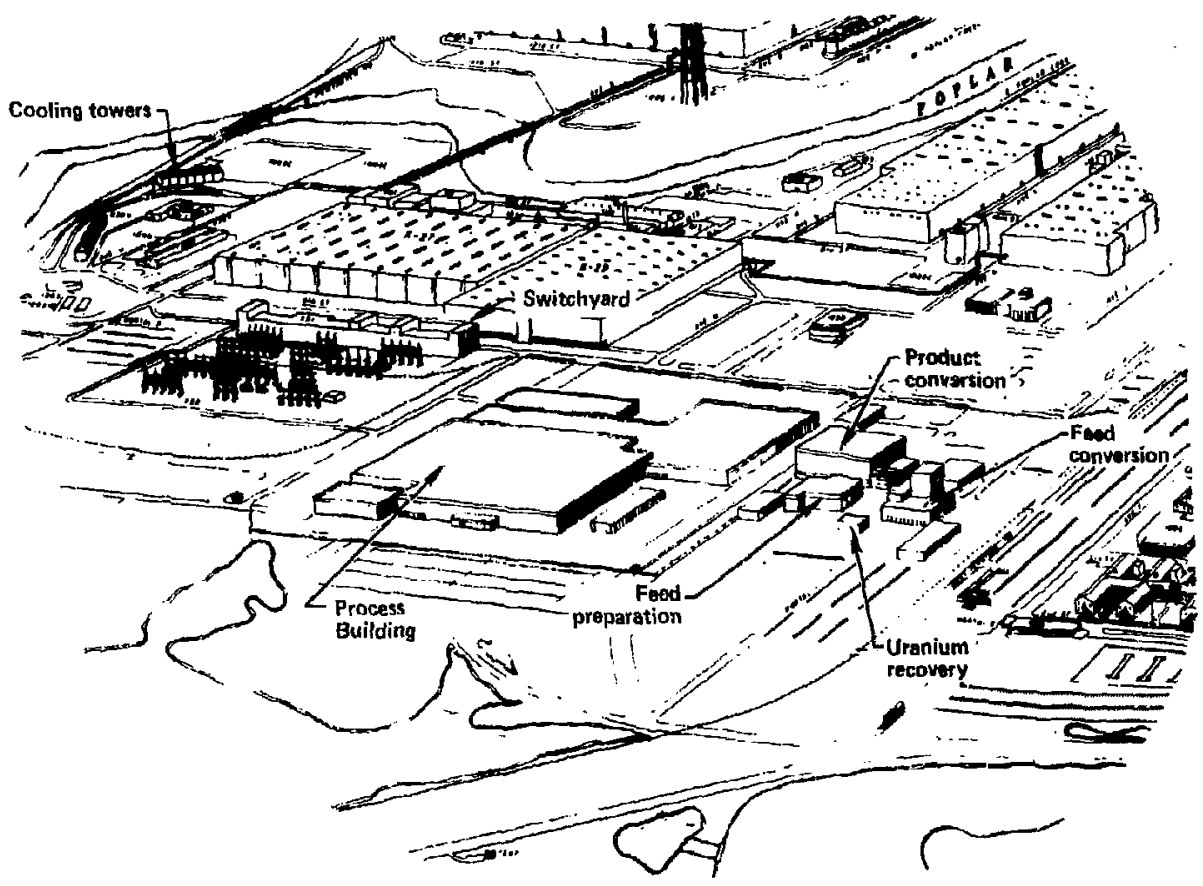

Fig. 1-2. Concept of the AVLIS Production Plant to be located at the $k-25$ enrichnent site in Oak Ridge, Tenn. 
Initial increment of production

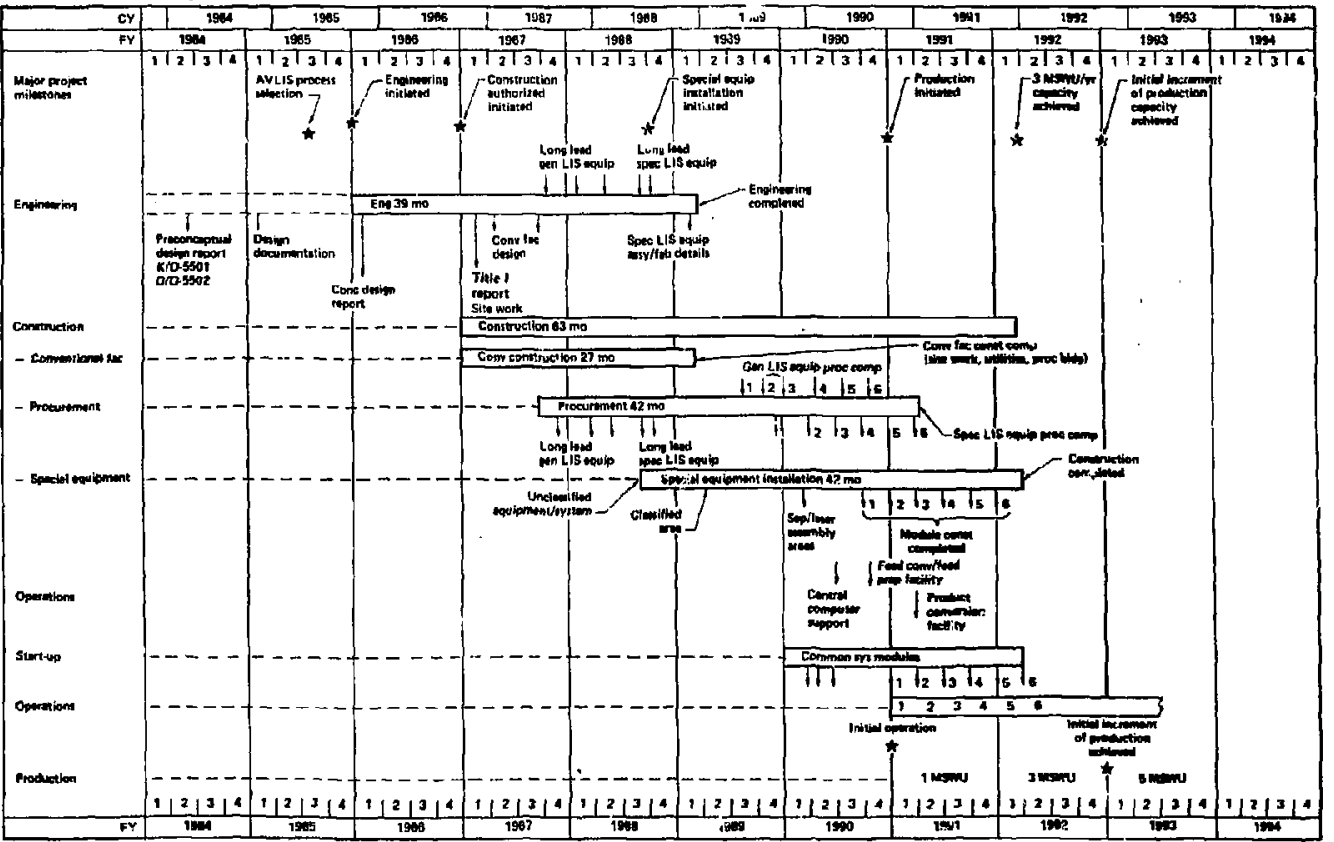

Fig. 1-3. Master schedule for the AVLIS Production Plant. 


\subsubsection{Scope}

The Industrial Access Program has been developed to facilitate the procurements of the AVLIS program for the first AVLIS Production Plant. Lawrence Livermore National Laboratory is the primary development organization for AVLIS, and will continue to provide technical support during the construction and start-up phases of the production plant. Martin Marietta Energy Systems, Inc., is coordinating the planning for the construction management, engineering, and operation of the AVLIS Production Plant. These two organizations have been responsible for procurements during the engineering demonstration phase. A procurement management organization, under the direction of Mart in Marietta Energy Systems, Inc., will have the responsibility for administering the procurements for the first production plant.

\subsubsection{Strategy}

Procurements for the AVLIS Production Plant will be structured so that the suppliers provide equipment at a level of performance and integration complexity that is within their demonstrated capability, and a: a level that is consistent with the refurbishment requirements and practices of the operating plant.

Because of this overall strategy, commercially available equipment with low refurbishment requirements (i.e., cooling, vacuum, and power systems) will be procured as turn-key systems. Equipınent that will be ubstantially refurbished many times over its useful life (i.e., laser heads, collector components) will be procured at the subsystem level needed to support the refurbishment recycle operation. Any needed assembly of subsystems will be performed in the plant refurbishment areas. 
Many AVLIS Production Plant procurements, in both che high technology and standard equipment areas, will be suitable for small business participation. The AVLIS program is taking full advantage of this to diversify the production plant suppijer base and to utilize these potentially lower cost sources of supply. Supplier qualification ensures that AVLIS suppliers are capable of providing reliable support.

The reinforcement of the existing base of comercial suppliers has been a major objective of the AVL IS engineering denonstration program. During the engineering development phase, modified products and developmental materials/equipment are being procured and tested to qualify these products and their manufacturers. The differences in program needs, required supplier capabilities, and contracting methods between the different project phases are described in later sections of this document. Standard competitivo practices will be followed for AVLIS procurements. The overall strategy of the Industrial Access Program is discussed in Section 2 of this document.

\subsubsection{Cata Base}

A procurement and supplier data base has been developed to support the AVLIS program and its Industrial Access Program. The commercial availability of specific equipment items, lists of suppliers, breakdowns of estimated costs, projected schedules for the project (deployment, expenditures, etc.), and a current list of the equipment to be finalized during the demonstration phase comprise the information contained in the data base. This data is being updated and maintained as information becomes available. The data base, its contents, and its uses are discussed in Section 3 of this document.

\subsubsection{Action Plan}

The Industrial Access Program is a vehicle for the identification of potential suppliers for the AVLIS program and the AVLIS Production Plant. The production piant cost breakdown included in the Industrial Access Program data base will be used as a basis to advertise the needs of the 
program. Supplier conferences will be used to provide further detail to interested companies on how they can support the construction and operation of the AVLIS Prodiction Plant project.

The management of the AVLIS Production Plant construction project will invalve the tracking of some procurement items that require special attention. The ordering of some equipment (such as large vacuum tanks) requires a long lead time, with special attention paid to the scheduling of these procurements. The technological development and/or reliable supply of a few nieces of AVLIS proress equipment (such as some laser and separator power supplies) is not currently availatle at the quality or cost desired for the plant. These items will be tracked to ensure the requisite quality and availability standards for the plant.

The AVLIS program and the AVLIS Production Plant project are expected to result in advances in technology with spin-off applications on a number of lovels, some as simple as improved manufacturing techniques and others as complex as new industrial photo-chemical processes based on lasers. The Industrial Access Program will facilitate the program/industry interactions needed for effective spin-off of AVLIS technology for elternate applications.

Section 4 of this document discusses the action plan to be followed for these areas of the Industrial Access Program. 


\section{PROCUREMFNT STRATEGY}

\subsection{BACKGROUND}

\subsubsection{Program Description}

AVLIS is a process that is being developed by Lawrence Livermore National Laboratory, Livermore, California, and Martin Marietta Energy Systems, Inc., in Oak Ridge, Tenn. This process enriches natura? uranium to provide fuel for nuclear reactors. The Bepartment of Energy has responsibility in the United States for providing enrichment services to the commercial nuclear power industry. The AVLIS program is currently involved in a peer review process that will determine whether AVLIS or the advanced gas centrifuge process will becme the technology that receives the major support for continuing toward implenentation of a full-scale production facility to supply low-cost product for the U.S. uranium enrichment enterprise.

Numerous sub-scale experiments over the past 10 years at LLNL and Martin Marietta Energy Systems: Inc., have already successfully demonstrated the technological feasibility of the AVLIS process. Fully functionally integrated demonstrations of the AVLIS process equipment have been achieved in the past and will be continued in 1985 with a full-scale laser system. Figures 2-1 and 2-2 conta in photographs of the experimental equipment that has been used in developinent work at LLNL. Full-scale system operations in 1987 will complete the engineering derionstration phase of the AVLIS program. The next phase will be the final design and construction of the AVLIS Production Plant that is described in subsection $? .4$ of this document.

\section{I.2. Process and Equipment Descrintion}

The AVLIS process is shown schematically in Fig. 2-3. Metallic uranium is melted and vaporized to form an atomic vapor stream. This vapor stream flows through the collector where it is illuminated by precisely tuned laser light. The U-235 atoms become electrically charged by photoionization and are removed from the vapor siream as product by an electromagnetic fieid. Unaffected $\mathrm{U}-238$ atoms pass through the product collector section and are withdrawn as tails. Figure 2-4 presents a sketch of how the AVLIS equipment will work in a production plant. 


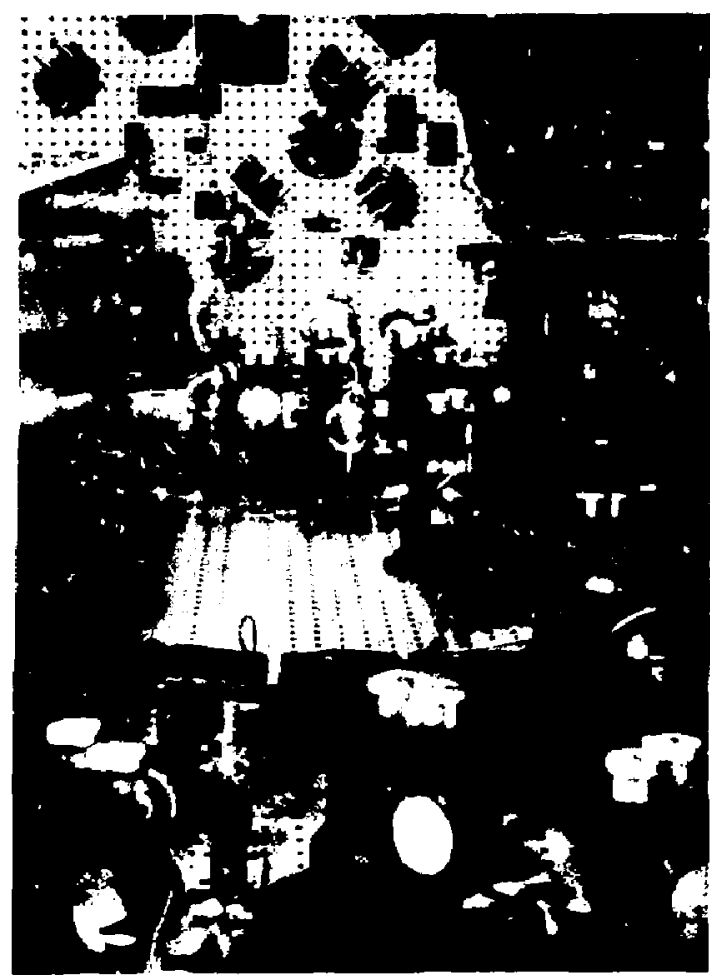

5

i)

i)

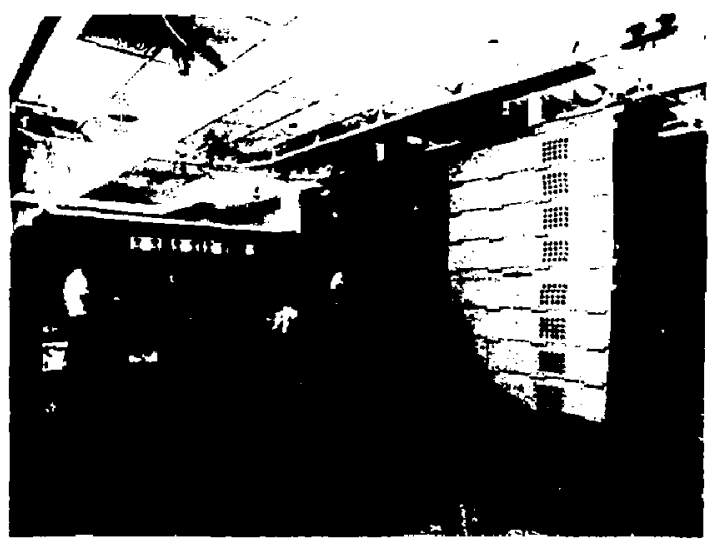

0

0

Fig. 2-1. Functionally integrated laser systems at LLiNL: waveform generator (top), and amplifier (bcttom). 

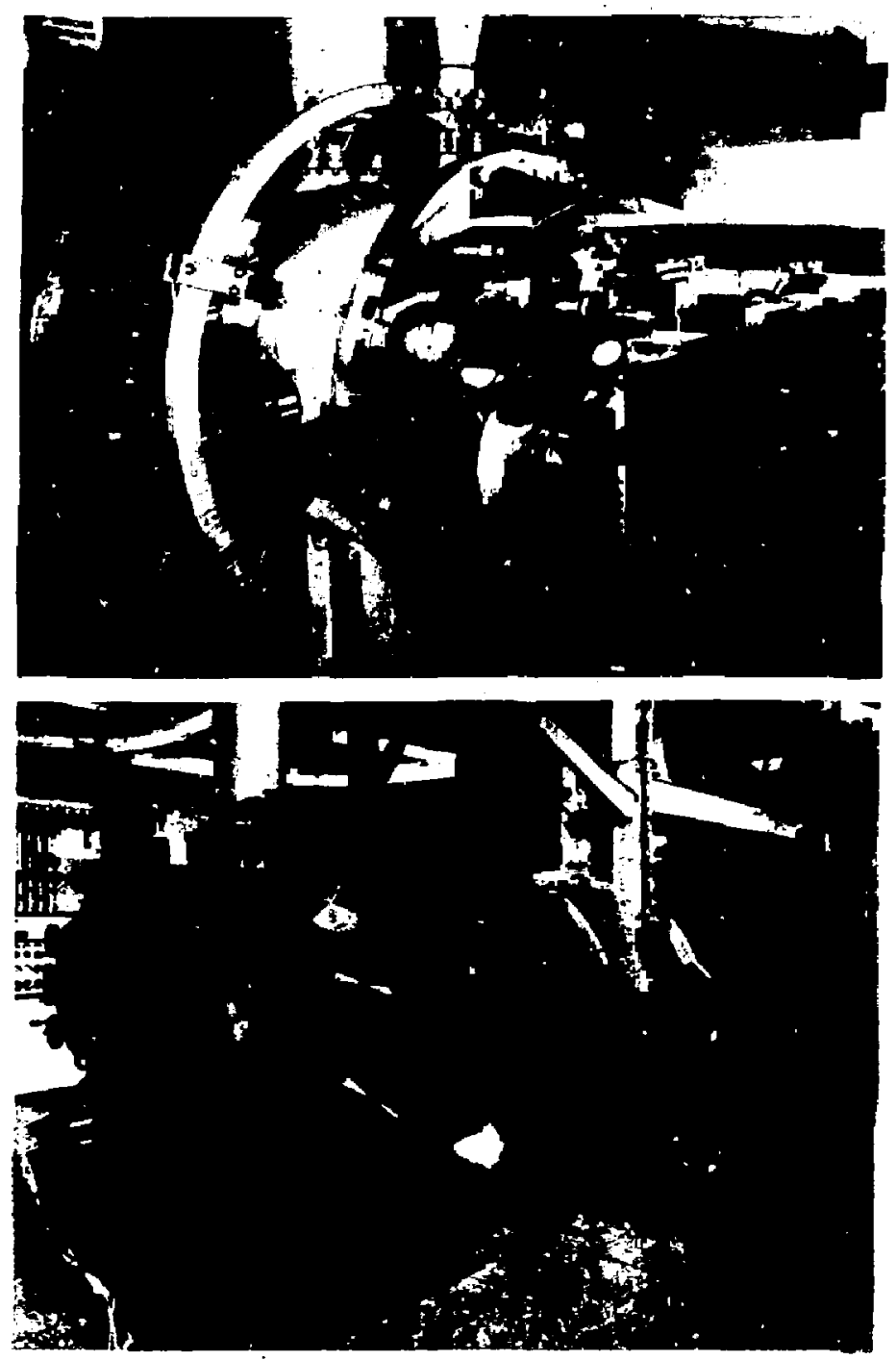

Fig. 2-2. Functionally integrated separation systems at LLNL: pre-protatype (top), and half-scale (bottom). 


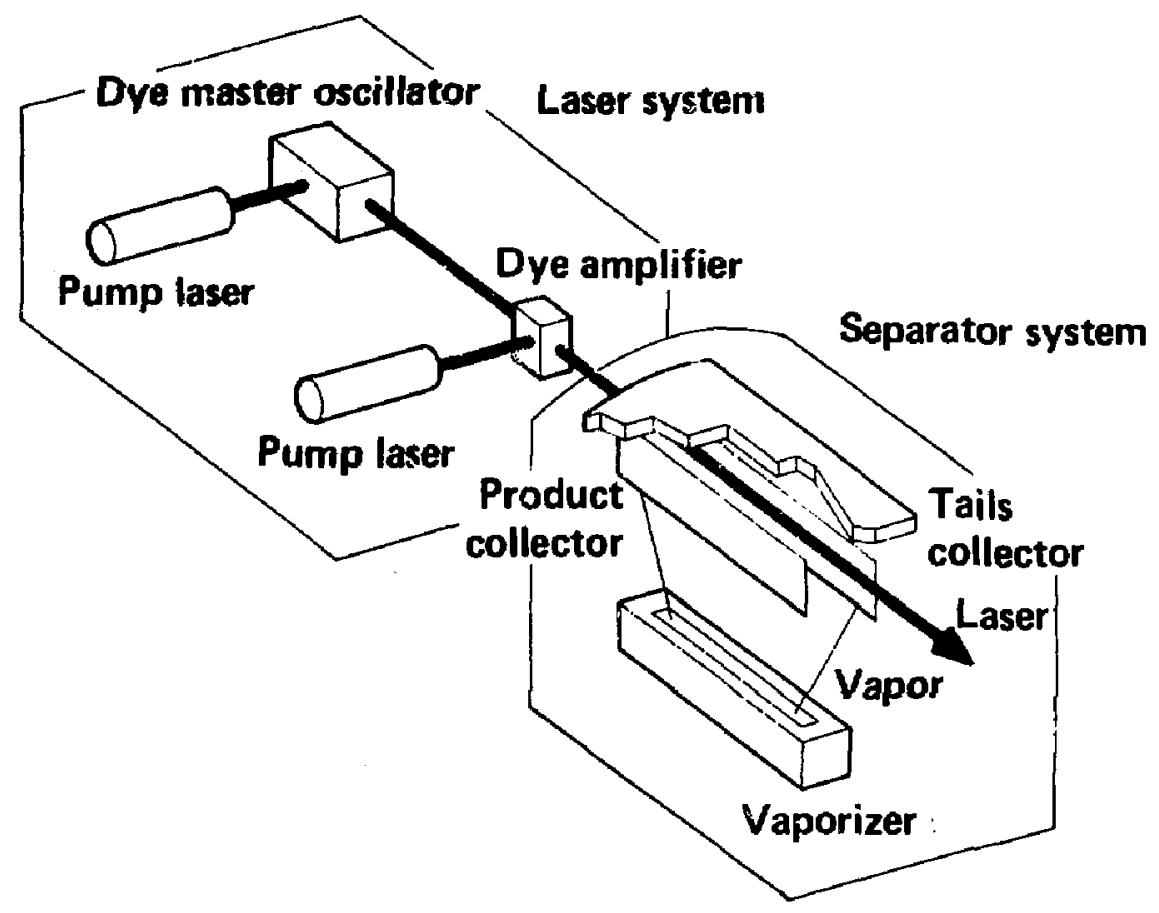

Fig. 2-3. Schematic of the AVLIS process systems.

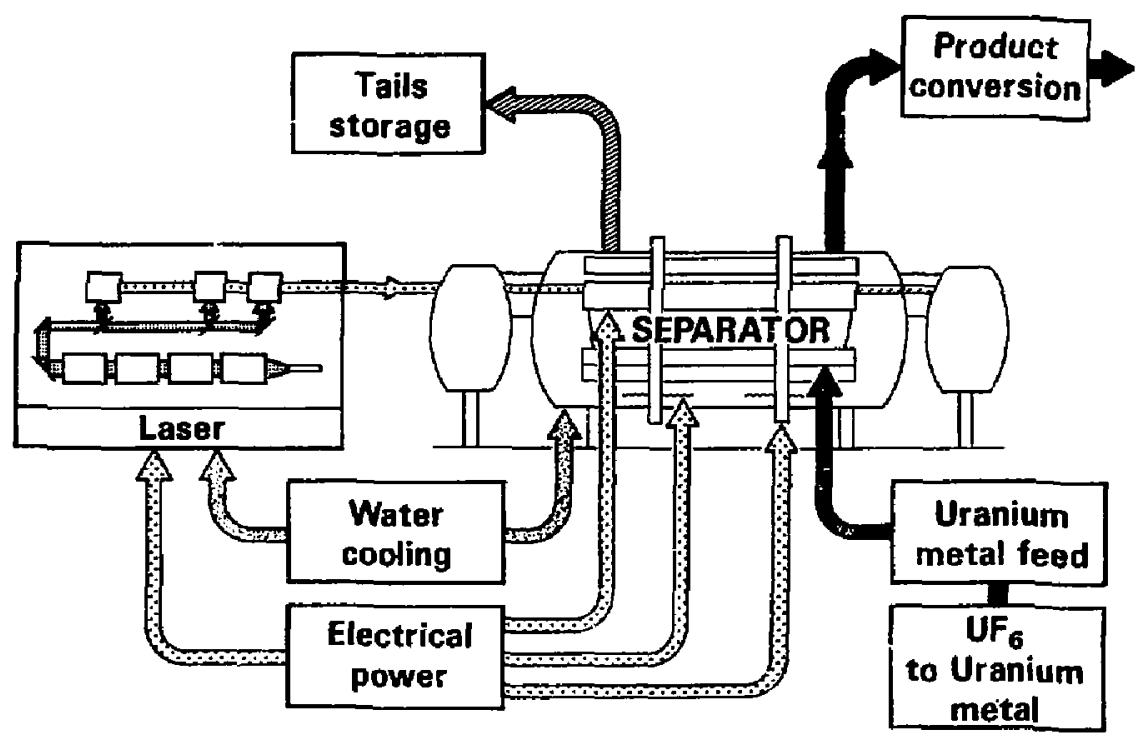

Fig. 2-4. Flow chart for the AVLIS process equipment. 
The vaporizer uses an electron beam to heat uranium metal contained in a crucible, thus forming the uranium vapor. This has been standard practice for many years in commercial metal refineries and processing plants for such metals as steel and.titanium. This subsystem is now well developed, with the specific temperatures, materials, etc. being optimized for the AVLIS process. Figure 2-5 contains a photograph of the Material Handling Demonstration Module at Oak Ridge.

The collector structures are a key element of the AVLIS process. Again, the basic technology of uranium foundries has been adapted. Specific design details for AVLIS equipment are different from those in cormon industrial use, but intermediate-sized collectors have now been assembied and tested at LLNL and Martin Marietta Energy Systems, Inc., in Oak Ridge, Tenn.

The AVLIS laser system consists of dye lasers that are pumped by copper-vapor lasers. Figure 2-6 presents a schematic of the AVLIS copper-vapor and dye laser systems. Both laser systems are configured in parallel master-oscillator, power-amplifier chains. The dye. lasers produce and amplify the precise colors (red-orange) that are used in the uranium photoionization and separation process. The copper vapor lasers (green-yellow) pump the dye lasers; that is, the copper vapor laser light is absorbed by the dye and re-emitted as red-orange light.

The principle elements of the dye system are the flow system (pumps, filters, piping) that pumps the dye (dissolved in alcohol) through the laser head, the laser head itself, and the dye. The flow channel in the dye head, which has precise, polished surfaces, has been comeicially procured since it was first designed for experimental evaluation. This element and all other parts of the system, including the electra-optics, are commercially available.

The copper-vapor laser system consists of several subsystems that iaclude the laser head, pulsed power, gas supply and vacuum, the unit enclosure, and the system support structures. All of these elements are currently being procured commercially. The pulsed power systems are being manufactured specifically for AVLIS. The design is expected to have wide spread use for other applications. Elements of the laser head are also being manufactured specifically for AVLIS. It is expected that the 


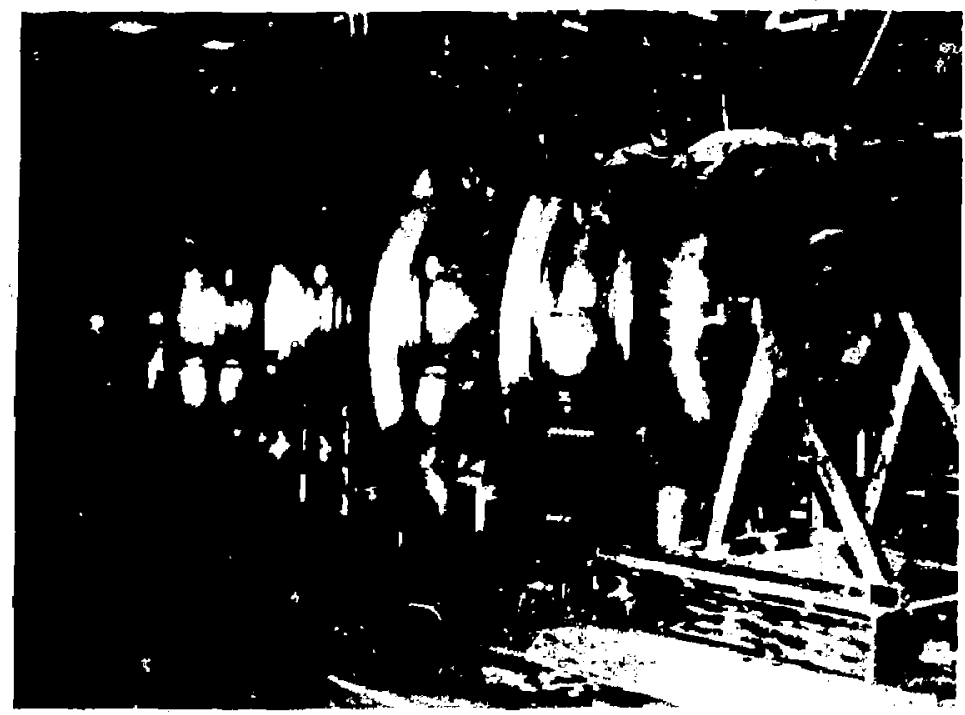

Fig. 2-5. The Material Handling Demonstration Module at Oak Ridge, Terin., is being used to examine various aspects of the separation process: uranium feed, vaporization, condensation, flow, and casting.

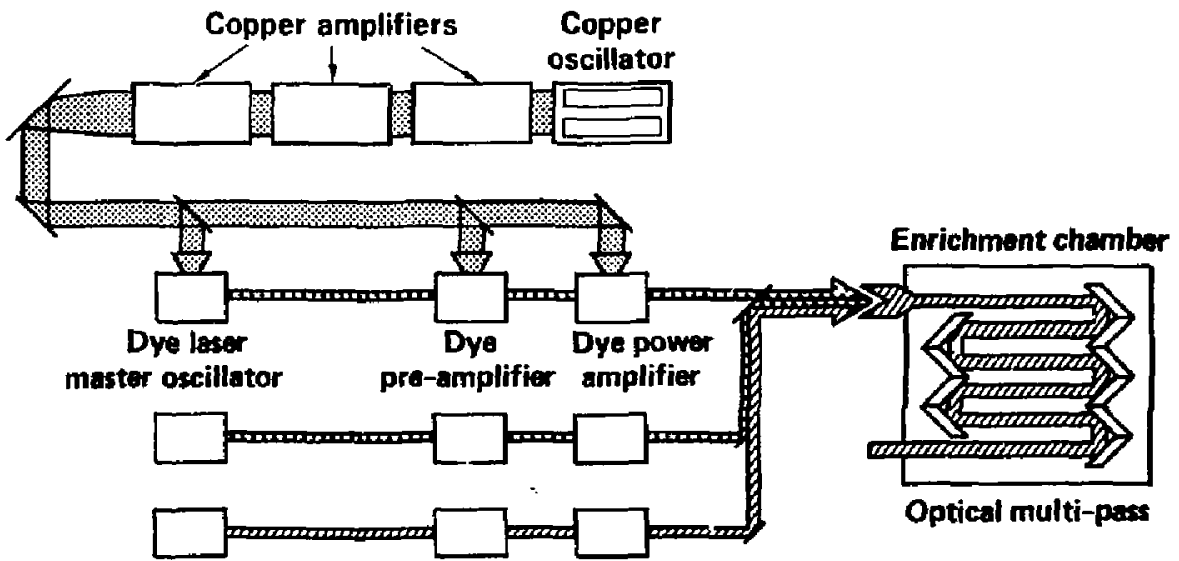

Fig. 2-6. Schematic of the coppor vapor and dye laser systems configurations. 
AVLIS requirements for these components will stimulate additional markets that will result in economies of scale and in decreases in cost to AVLIS. Finally, the many optical elements in both laser systens and in the saparation chamber are being procured comercially. In this case, AVL IS will continue to pursue better reflectivity and coating durability. Although the system does not stress the basic properties of the materials, improvements in coating performance will continue to improve both capital and operating costs.

The laser system controls and diagnostics are standard commercial products available froin multiple suppliers.

\subsubsection{Nature of Procurements}

Procurements for the AVLIS Production Plant will utilize standard, competitive practices. A concerted attempt has been made to match the requirements of the production plant process equipment to the established capabilities of industry. A11 AVLIS materials and equipment are currently available from commercial suppliers. Some improvement in price and performance is still desired and expected for specific items (power supplies, optical coatings, ceramic parts of proper size and shape). For these items, pre-procurement supplier qualification development activities are undemay as part of the engineering development program.

The extent of these qualification development activities yary from item to item, depending on the degree of similarity of the desired items to products already on the market. In other words, the activities for some products take more time and are more comprehensiye than the activities for slight modifications of currently available products.

The objective of the qualification development activities is, of course, the achievement of production quality equipment and materials for the AVLIS Production Plant. AVLIS technical personnel are interacting closely with the potential suppliers during the pre-procurement qualification development programs to ensure that the process requirements for the AVLIS equipment are met. Several manufacturing iterations may be required before products of production quality are achieved. 
Procurements for the AVLIS Production Plant will include construction services contracts, engineered equipment contracts, and material and equipment orders for both conventional construction and sperial equipment. Conventional construction covers site preparation, landscaping, utilities, buildings, and building systems, Special equipment includes the process and support systems that conplete the plant.

Corventional construction services will be procured from contractors who serve the general area of the AVLIS Production Plant. As stated earlier in subsection 2.1.3., conventional construction contracts will be awarded using stindard competitive procurement practices. All procurements that require a long lead time (due to material availability or other factors) will be scheduled to allow time for adequate competition. Figure 2-7 outlines the practice to be followed for the procurement of standard equipment.

All special equipment procurements will be the responsibility of the construction project procurement organization. The procurement of special equipment will in some cases involve AVLIS technical staff directly in the pre-procurement qualification development activities that were discussed above in subsection 2.1.3. The model for this interaction is the standard contracting officer/technical representative relationship. AVLIS tecinical personne? will prepare the equipment specifications and ascertain the quality of the manufactured items. AVLIS program technical and procurement staff will assist the construction project procurement personne] upon request in the identification of any equipment items with special procurement requirements. 


\section{Example: Vacuum System}

\section{Oualification - 1. Preliminary vendor qualification \\ 2. Competitive procurement \\ Procurement \\ 3. Manufacture and delivery/installation}

Fig. 2-7. Pracurement of standard equipment and fabrications, such as vacuum systems and mechanical laser parts.

The special equipment items requiring qualification development activities are categorized as modified products and developmenta 1 materials/equipment, As mentioned above in subsection 2.1 .3 , the qual if ication of these items involves close interaction between AVL is program personnel and the potential suppliers. Care is being taken during the qualification development phase to preserve competition among the suppliers. After the qualification development activities have resulted in qualified products and suppliers, the AVLIS Production Plant procurement organization will conduct the procurement competition. For appropriate cases, the final procurement will be split (approximately 60\%-40\%) between the two most qualified suppliers so that a back-up supplier will be available.

Modified products are items that are already available, but that need to be altered to meet the requirements of the AVLIS Production Plant. Figure 2-8 presents the practice to bo followed for the procurement of modified products. The pre-procurement qualification development activities required for modified products include sample procurement and testing iterations before the competitive selection of the supplier. These activities also provide a contractual mechanisin for the interaction that is needed between the AVLIS organization and the potential production plant suppliers. 


\section{Exemple: Optical Coatings}

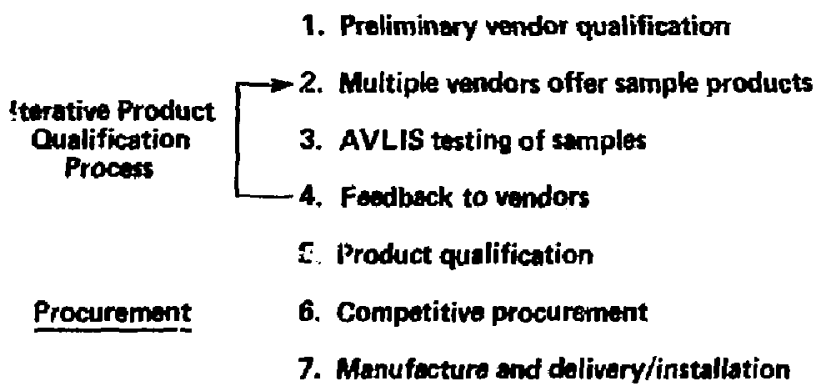

7. Manufacture and delivery/installation

Fig. 2-8. Procurement of modified products, such as optical coatings.

A piece of developmental material/equipment (e.9., power supplies? is different from a modified product (e.g., optical coatings) in that the suppliers do not have an existing product that closely resenbles the needed item. In the case of optical coatings, there will always be a substantial economic payoff in reaching beyond current practice to higher reflectivity. This item is currently considered developmental, and will rems in a modified product procurenent even after parts have been delivered to the plant, in order to encourage further improvement. Developmental material/equipment suppiiers participate in an iterative design, prototype, and testing process as part of the qualification development activities. The close interaction between AVLIS staff and the potential suppliers that is required for modified products is more inportant for developmental material/equipment. The risks associated with developmental products are higher than for the other procurements, since more complex improvements are required. Figure 2-9 outlines the pract ice to be followed for the procurement of developmental materials/equipment. At this time, the number of items on the developmental materials/equipment list (see Section 3.6) is less than ten. 
Example: E-beam Power Supply

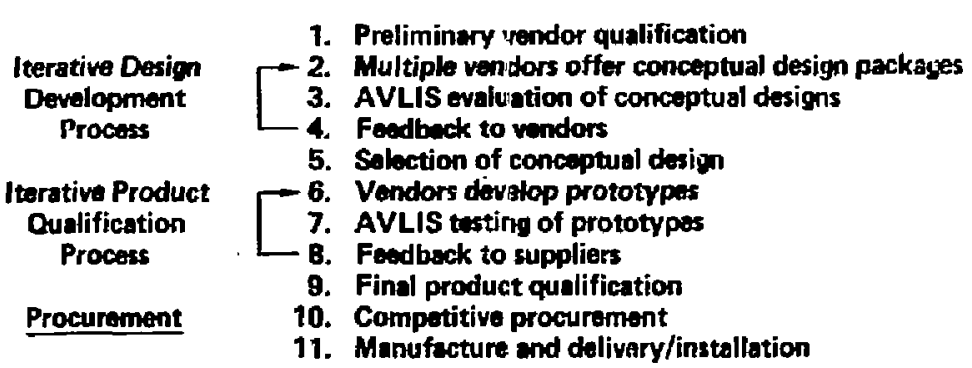

Fig. 2-9. Procurement of developmental material/equipment, sich as E-beam power supplies.

2.2. OISZUSSION

2.2.1. Pracurement Guidel ines

A mojor goal of the AVLIS program is to develop a reliable supplier base that will effectively support the construction and operation of the AVLIS Production Plant. The consideration of the plant operational requirements dictates a different procurement philosophy for some specia] equipment than applies to conventional construction. The Industrial Access Program häs been developed to ensure that adequate attention is paid to the special AVLIS procurement considerations.

\subsubsection{Basis for Level of Procurement Complexity. The AVLIS} organization follows a general policy of procuring equipment at the highest level of system complexity that industry can provide in accordance with normal construction and manufacturing practice. There are, however, twi inajor exceptions to this policy. These two exceptions 
concern: the existence or potential of a market for the product beyond AVLIS; and the operational refurbishment requirements of the AVLIS Production Plant.

External Market. In genera 1, long-term supplier reliabifity is degraded if there are no external customers. A strong external market ensures a competitive supply. Therefore, unless there is an existing or potential strong market, the equipment needed for AVLIS will be procured at a lower level of system complexity (subsystem, component, part, etc.) than needed so as to procure at the level that the external market can support. The general procurement policy is to procure at the highest Tevel of integration that is supported by an axternal market. Figure 2-10 illustrates how external market conditions affect the AVLIS Production Plant procurement strategy.

\begin{tabular}{|c|c|c|}
\hline $\begin{array}{c}\text { EXTERNAL MARKET } \\
\text { STRENGTH }\end{array}$ & $\begin{array}{c}\text { PREFERRED PROCUREMERJT } \\
\text { STRATEGY }\end{array}$ & ALTERNATIVE STRATEGY \\
\hline Strong & $\begin{array}{c}\text { Procure at desired } \\
\text { integration level }\end{array}$ \\
\hline Potential & $\begin{array}{l}\text { - Procure at available } \\
\text { integration level } \\
\text { - Transfer technology, then } \\
\text { Procure at desired } \\
\text { integration level }\end{array}$ \\
\hline No prospect & - Procure at available \\
intogration level & \\
\hline
\end{tabular}

Fig. 2-10. External market strength effect on the AVLIS procurement strategy: AVLIS is using suppliers' capabilities within their experience base, but strongly encourages new products when these favor plant econamics. 
AVLIS Plant Refurbishment. The AVLIS process separator and lasers are designed in a modular fashion. This modularity helps to minimize operational downtime, since repairs and refurbishment will be performed away from the operating floor. The modular units will be refurbished on-site in dedicated separator and laser refurbishment areas and recycled back into operation. Figures 2-11 and 2-12 contain sketches of the separator and laser module refurbishment breakdowns.

The separator and laser-system units each have a characteristic recycle rate, determined by the components with the shortest lifetimes--the recycle rate is equai to the inverse of the number of hours between routine refurbishment. After a number of recycle operations, when the components with long lifetimes reach the end of their lives, a unit will have to be totally replaced. Recycling separator and laser subsystems, rather than simply replacing them, is economically justified because the overall unit life is far longer than the life of the replaceable elements.

The AVLIS organization does not require its suppliers to develop capabilities in support of construction that cannot be fully used during operation. The AVLIS Production Plant construction costs would otherwise increase, since the supplier's additional capitalization cost would have to be recovered in the initial construction procurement. Since the production plant refurbishment areas will have a large assembly Capability, the AVLIS plan is to perform the initial assembly there also. This will simplify procurement and shipping requirements, and will ensure quality control. Figure 2-13 illustrates how these refurbishment considerations will mesh with the external market conditions (shown in Fig. 2-10) to produce the overall AVLIS procurement strategy.

While this procurement strategy is the mast economical in general, exceptions will be made in two cases. First, when the required subsystem units closely resemb le commercially available equipment, the externa? market influence would overshadow the benefits of on-site assembly. Second, when the cost of the shortest lifetime components approach the cost of the entire unit, it may be more economical to replace the entire unit. In these two cases, entire units will be procured initially and as replacements, along with any spare components determined to be useful. 


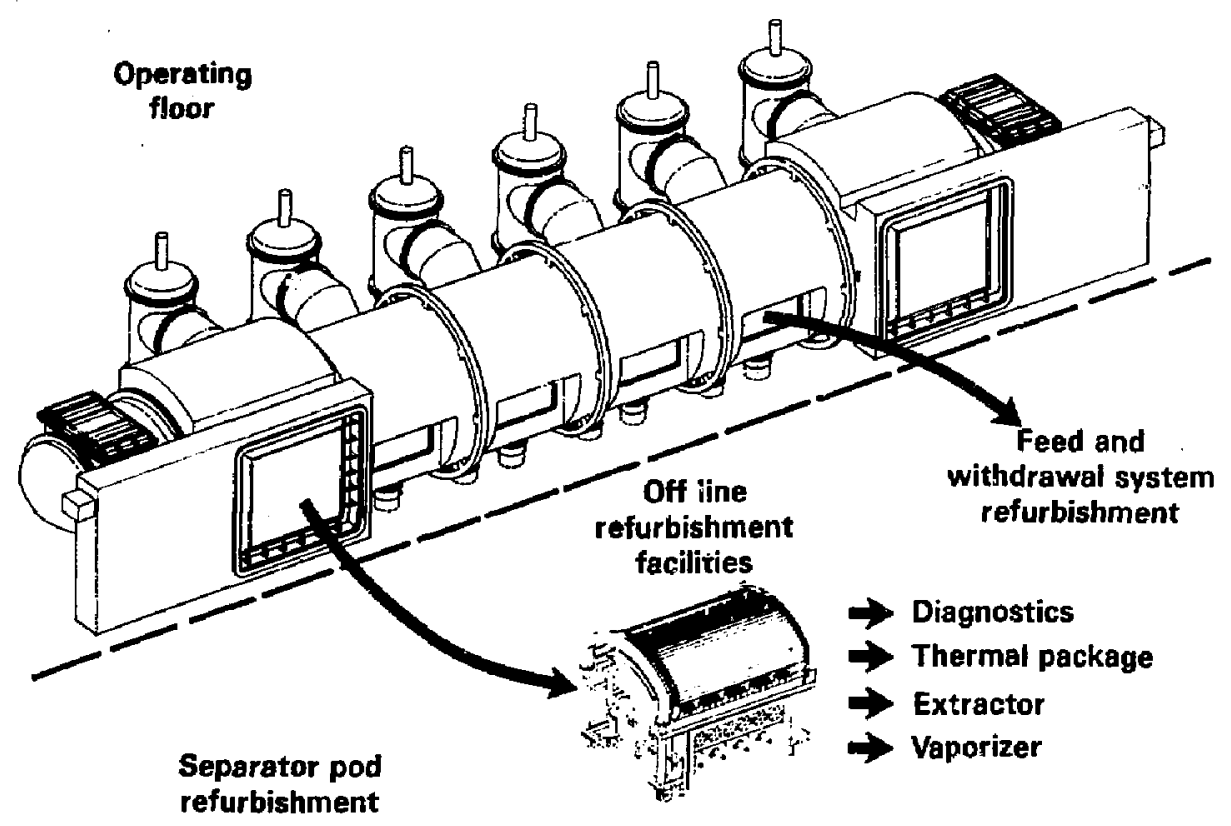

Fig. 2-11. The operability of the AVLIS separator system is supported by on-site repair and refurbishment.

Recurbishment will be performed at the component level only in cases where it proves to be economically appropriate (such as random, infrequent fajlures of inexpensive components). The actual operational experience of the AVLIS Production Plant may eventually dictate a revision of these procurement and replacement strategies toward replacement of entire units as the un t costs decrease and the unit component liyes are extended.

\subsubsection{Transition from Engineer ing Development to Construction}

Procurement. During the early developmental phase of AVLIS, the design, prototype development, and experimentation was done primarily within the development organization (LLNL and Martin Marietta Energy Systems, Inc.). 


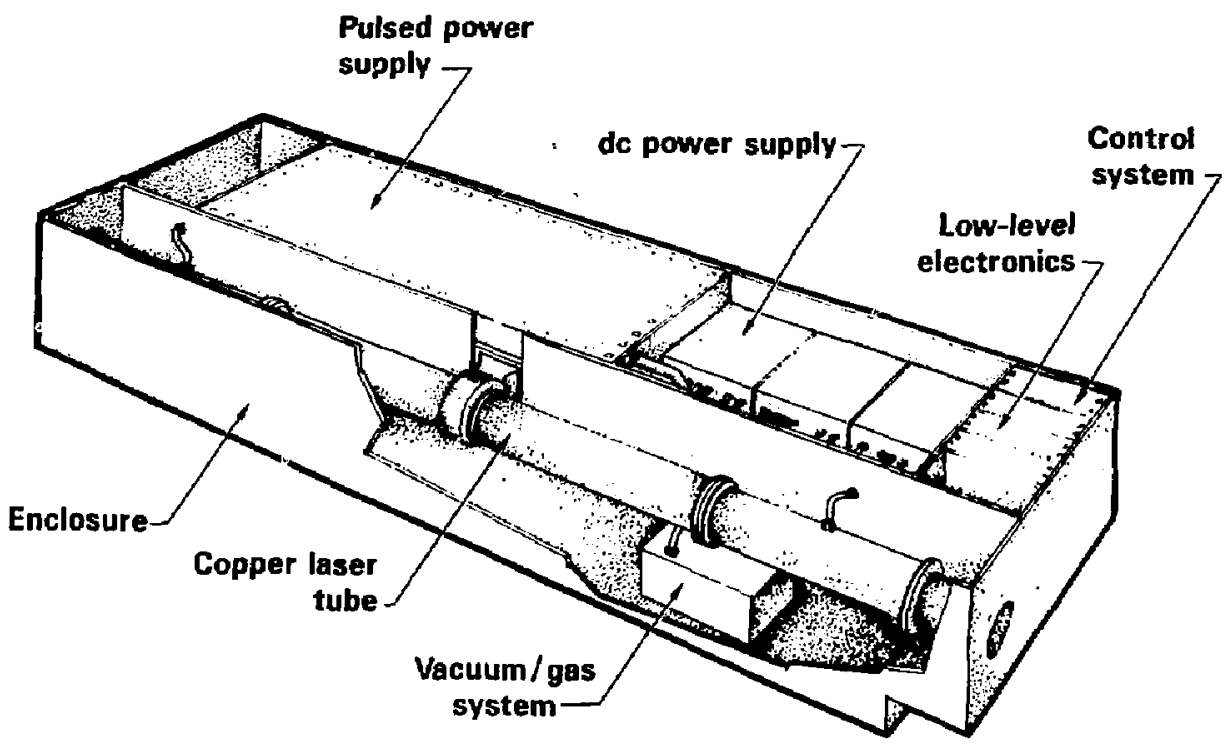

Plant prototype packages are now being procured as build-to-print items

Fig. 2-12. The laser system modules are refurbished offline utilizing plug-in subsystems and replacement of complete units online.

The suppliers nave provided materials, conventional services, standard equipment, and build-to-print components. Exceptions to this generalization are pilsed power systems, instrumentation, and integrated mechanical systems (e.g., vacuum, cooling, structures, gas supply), which are currently being supplied as complete systems and subsystems.

For the construction of the Full-Scale Demonstration Facility, laser subsystems (pulsed power systems and control modules, for example) are being assembled and tested by the suppliers. The level of procurement nas moved from components to subsystems. 


\begin{tabular}{|c|c|c|c|}
\hline & $\begin{array}{c}\text { EXTEFNAL MARKET } \\
\text { STRENGTH }\end{array}$ & $\begin{array}{l}\text { PAEFERRED } \\
\text { STRATEGY }\end{array}$ & $\begin{array}{l}\text { BACK-UP } \\
\text { STRATEGY }\end{array}$ \\
\hline \multirow{3}{*}{ Throwaway } & Strong & $\begin{array}{c}\text { Procure } \\
\text { finished item. }\end{array}$ & \\
\hline & Potential & $\begin{array}{c}\text { Procure at available } \\
\text { integration level. } \\
\text { Encourage } \\
\text { commercialization. }\end{array}$ & $\begin{array}{l}\text { Procure parts. } \\
\text { Assemble in plant. }\end{array}$ \\
\hline & No Prospoct & $\begin{array}{c}\text { Procure at } \\
\text { available integration } \\
\text { level. }\end{array}$ & \\
\hline \multirow{3}{*}{ Recycle } & Strong & $\begin{array}{l}\text { Procure at level } \\
\text { of replacement item } \\
\text { that is economical. }\end{array}$ & \\
\hline & Potential & $\begin{array}{l}\text { Target procurements at } \\
\text { level of replacement } \\
\text { items and encourage } \\
\text { commercialization. }\end{array}$ & $\begin{array}{c}\text { Procure parts. } \\
\text { Assemble in plant. }\end{array}$ \\
\hline & No Prospect & $\begin{array}{l}\text { Procure at } \\
\text { available integration } \\
\text { level. }\end{array}$ & \\
\hline
\end{tabular}

Fig. 2-13. AVLIS equipment procurement strategy is determined by refurbishment practices and the strength of the outside market.

During the construction phase of the AVLIS Production Plant, however, the suppliers will provide larger quantities and second or third generation versions of these subsystems. There will be no more developmental work at this stage, except in cases where the advantage of performance improvements is nigh and the development risk is low. Figure 2-14 illustrates the transition from development, through engineering demonstration, to construction.

The expanded role taken by the suppliers during AVLIS Production Plant construction requires preparation by both the AVLIS developers and the suppliers. The Industrial Access Program is focusing the attention of the engineering development organization on the procurement needs of the production facility. Care is being taken during the engineering development phase to utilize multiple suppliers who are capable of 


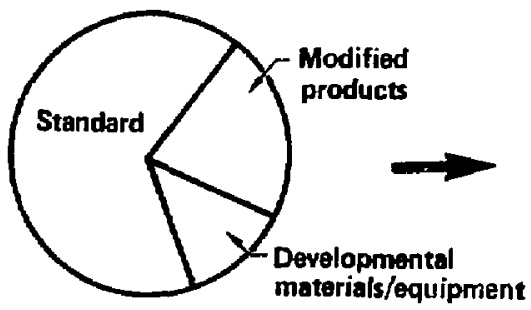

Development Phase

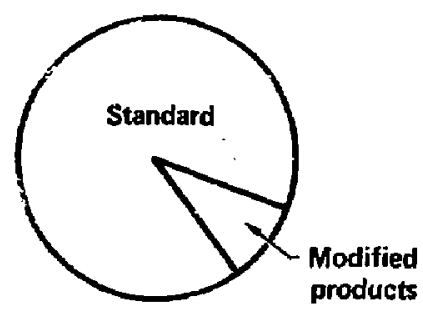

Construction Phase

Fig. 2-14. One objective of the engineering development program is to identify a supplier network such that a 11 construction phase procurements are either standard equipment or modified product competitive procurements.

manufacturing at the scale that will be needed for production facility construction and operation. Secondly, contracts with potential suppliers in the qualification development activities for modified products and developmental materials/equipment are structured to ensure competitive procurement for the production facility.

The AVLIS program is in transition from engineering development to full facility construction. The Full-Scale Demonstraticn Facility is being built at LINL in Livermore, California. Figure 2-15 shows a cut-away sketch of the Full-Scale Demonstration Facility, which will include hardware that represents the prototype for the AVLIS Production Plant. In the future, it is also expected to serve as the test-bed for AVLIS process equipment improvements. The procurement process for the laser and separator hardware to be included in this facility allows the AVLIS engineering developinent organization and some of the potential production plant suppliers to interact on both standard and developmenta] equipment. The benefits for the AVLIS Production Plant construction 
project include the development of an initial base of qualified suppliers and a smooth transition from developmental work to the plant construction phase. Figure 2-16 illustrates the role of the Full-Scale Demonstration Facility in the transition from engineering development to construction.

\subsubsection{Transition from Procurements from the Construction Phase to} Operations. After the AVLIS Production Plant is built, the procurements to support the operation of the facility will become standard in nature. Industries that have strong marlets beyond AVLIS will routinely support the needs of the production plant operation (control modules, pulsed power supplies, optical coatings, etc.). The remainder of the plant operational needs will be satisfied either by its on-site refurbishment facilities or by commercial suppliers who are capable of supplying AVLIS specialty items at lower cost than they can be repaired on site (a possible example is a laser head).

As discussed in subsection 2.2.1.1. of this document, the operational considerations of the AVLIS Production Plant strongly influence the overall construction procurement policy that.the AVL IS program will implement. The AVLIS Production Plant areas used to perform refurbishment operations will also be used for the initial assembly of the separator and laser system modules. The quantities of construction and operational phase procurements will be balanced as much as possible to avoid suppiier capitalization in excess of long-term operational needs. The effect of external market conditions on AVLIS suppliers will be considered to ensure a reliable supplier base for operation. Thus, the construction phase procurement strategy developed in the industrial Access Program will provide for a smooth transition to the operational phase. Figure 2-17 illustrates the transition of procurements from AVLIS Production plant construction to operation.

\subsubsection{AVLIS Technology Spin-offs. The Stevenson-Wydler Act was} established in 1980 to facilitate the transfer of technology from government projects to private U.S. industry. The development of the AVLIS process has spurred the advancement of existing technologies and has also resulted in the development of totally new technology. Although 


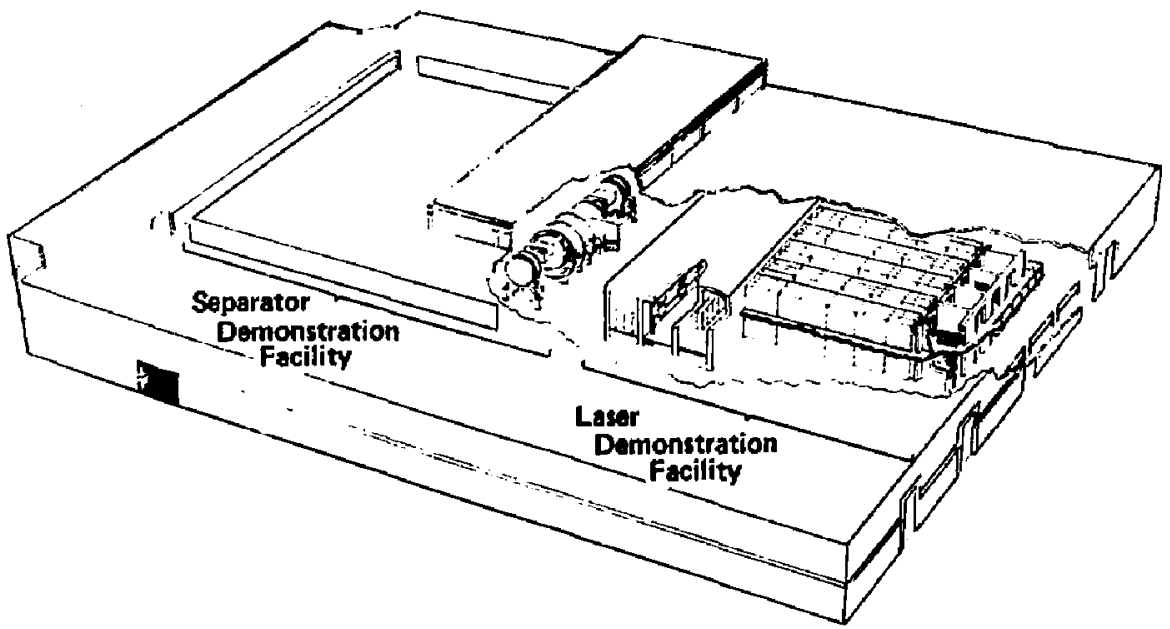

Fig. 2-15. The Ful]-Scale Demonstration Facility at LLNL represents the prototype for the AVLIS Production Plant separator and laser systems, and their supporting systems and facilities.

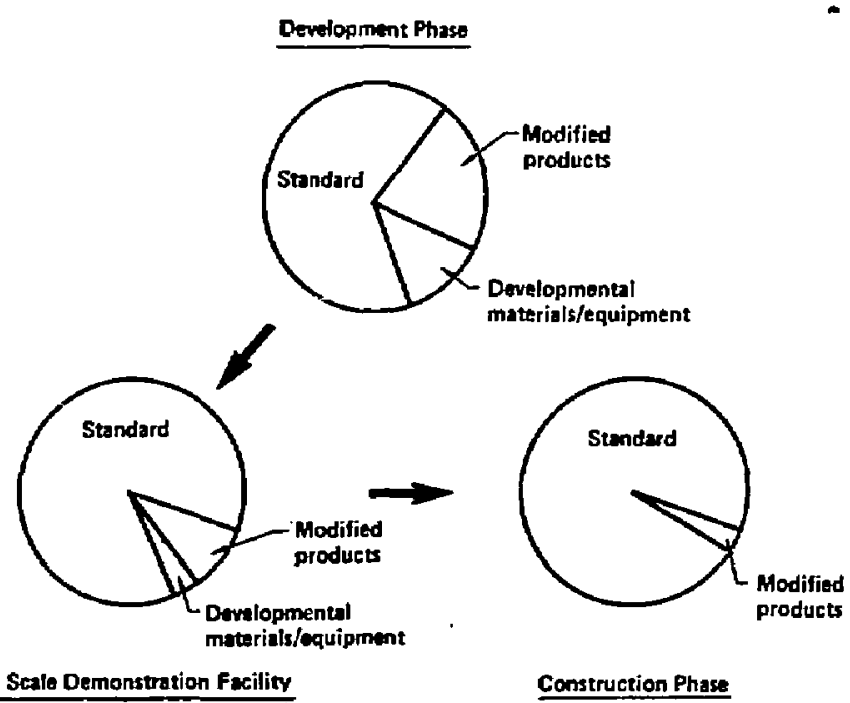

Fig. 2-16. The Full-Scale Denonstration Facility construction will complete the phase of developmental procurements. 


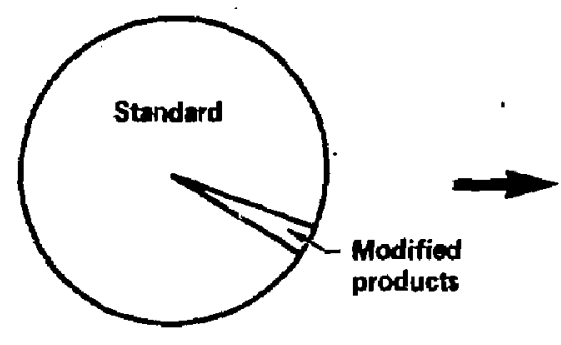

Construction Phase

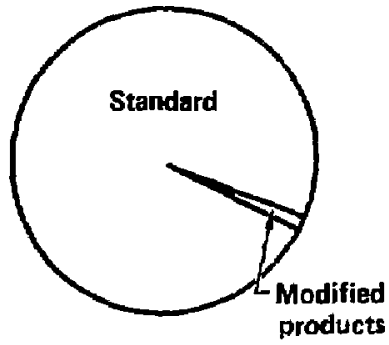

(for improvement)

Operations

Fig. 2-17. Procurements for the operation of the AVLIS Production Plant will be standard and competitive. Some items, such as optical coatings that can benefit from further improvement, may continue to be procured as modified products to stimulate supplier development.

no technology transfer is reguired for the production of AVLIS Production Plant equipment, technological advances will be made available for use by industry. This technology spin-off process is being promoted via the industrial Access Program.

The active transfer of technology by the All IS organization is limited by only two considerations: goals for non-proliferation, and the external market's potential. To impede the AVLIS process from being modified and extended (through additional research) for the production of weapons materials, some aspects of the process and equipment design are restricted.

Ihe AVLIS program will benefit from the commercialization of marketable AVLIS technology. Larger production levels will result in lower unit costs, because a manufacturing company can spread capitalization costs among all customers and can profit from its investment more quickly. Therefore, the AVLIS program's costs wou Td be reduced from those for one-of-a-k ind or limited-use products. In 
addition, the incentive of an expanded market will encourage the suppliers to develop more rapidly the products and services that are needed for AYLIS.

2.2.1.5. Sma 11 Business and Government Socio-Economic Guidelines. The Small Business Innovation Research Program was authorized by the Small Business Innovation Development Act in 1982. The DOE is a participant in this Program in the area of uranium enrichment technology research. Many of the procurement needs of the AVLIS Production Plant are well-suited to smal1 businesses, in part due to the build-to-print nature of many equipment procurements. For this reason, the AVLIS program places special emphas is on the utilization of smal? businesses for AVLIS Production Plant procurements.

All government-funded programs must be responsive to the procurement guidelines that have been established to assist disadvantaged businesses. The AVLIS program currently utilizes the guidelines that are sponsored for procurement of Department of Energy engineering development projects. These guidelines will also be applied for AVLIS Production Plant procurements so that the benefits of AVLIS technology are distributed throughout U.S. industry.

\subsubsection{Procurement Methods}

Normal competitive procurement practices will be used. Procurement solicitations will be issued along with drawings, specifications, and terms and conditions to interested suppliers. In cases where time is critical or the item to be procured has critical specifications, prequalification of multiple suppliers will be used. No developmental procurements are anticipated. First article acceptance tests may be used for some laser subsystems and components. Procurement liaison representatives from both LLNL and Martin Marietta Energy Systems, Inc., coordinate the procurements for the program engineeriig development phase and production plant construction phase. 
2.2.2.1. Requests for Quotations. The designated AVLIS procurement lialsons, with appropriate technical and scheduling input from AVL is Production Plant project personnel, will coordinate the preparation and scheduling of requests for quotations for all AVLIS Production Plant procurements. ilost production plant procurements, including materiel and services that are commonly offered by more than one supplier, long lead time items, and equipment developed through qualification development activities are being procured using this method.

Care $w i l l$ be taken that ihe initial requests for quotations contain sufficient information to el icit complete, competitive, and comparable proposals from an adequate number of suppliers. The Industrial Access Program is assisting this effort by the development of supplier lists in each of the major procurement categories. These lists are part of the Procurement and Supplier Data Base that is discussed in section 3 of this document.

The requests for quotations will contain a statement of the work to be performed, the quotation evaluation criteria, information concerning any prequotation supplier conferences, supplier qualification criterio, and any other information needed to assure that the quotation process proceeds efficiently. The entire quotation solicitation and evaluation process $w^{j} 11$ be structured so that small businesses and businesses owned by economically and/or socially disadvantaged persons have an opportinity to provide materiel and services for the AVLIS Production Plant.

\subsubsection{Contracting Options. AVLIS Production Plant equipment wil i be} bought using fixed-price contracts to the maximum extent practicable. Much of the component, fabrication, and subsystem procurement will be build-to-print at a fixed price. Construction work for the production plant will be done under fixed-price contracts, or by a cost-plus-award-fee contractor. Some standard seryices will be purchased on fixed-price, iime-and-materials contracts. In addition, during the qualification development activities for modifi, d products and developmental materials/equipment, cost-plus-fixed-fee contracts are being used. 
Modified Products. Selection of a supplier for a modified product will be based on an evaluation of sample articles. These samples will be "first articles," in that they result from the standard manufacturing techniques that will be used for the production run. Multiple suppliers who have undergone a preliminary qualification (see the subsectioil on Standard (riteria below) receive a fixed-price or other appropriate type contract (depending on the extent of the modification) to produce a representative sample of a piece of production equipment. The AVLIS organization is testing these samples and providing feedback to the suppliers. This sample production and testing process is repeated until acceptable items are produced. The qualified suppliers will compete for production of the item. The supplier and backup (if appropriate) selected will provide the equipment under fixed-price contracts.

Developmental Materials/Equipment. Developmental material/equipment is being obtained for the engineering demonstration systems following a sequence of conceptual design, prototype, and testing iterations. Once vendors have successfully gone through this process and have been selected, they will be able to begin finalizing the product design in cooperation with the AVLIS design teams. Currently, a combination of project engineering staff and singie or multiple suppliers are participating in these developments. The final design and possibly a backup are selected on the basis of the prototype.

As in the process for modif ied products, potential suppliers for developmental material/equipment undergo preliminary qualification screening. The qualifying suppliers develop the design and a prototype under fixed-price or other appropriate contracts. Other suppliers may also be solicited to bid on the production material/equipment procurement. The specific development sequence and participant responsibilities vary depending on the complexity of the item and the expertise of the participants. The AVLIS extractur power supplies are currently being obtained with this approach.

2.2.2.3. Vendor Qualification. Supplier qualification provides a measure of quality asstrance and facilitates procurements. Standard supplier qualification criteria and procedures are used for all items readily 
available. In addition, the qualification development actiyities discussed in Subsections 2.1.3. and 2.1.4. are used to qualify both supp?iers and production materials/ equipment for the AVLIS Production Plant. In many cases, the item procured is a catalog item and requires minimal additional supplier qualification and quality assurance.

Standard Criteria. The standard method of qualifying suppliers is to examine in detail their financial condition and performance record, analyze the current capabilities of their facilities, and determine the competence of their personnel to perform the work. This critical review identifies those suppliers that are capable of reliably providing the luality and quantity of equipment needed for production. The most efficient use of both AVLIS program ard supplier resources is ensured if only capable suppliers participate in the proposal process.

Modifiad Products. As discussed in Subsection 2.1.4., qualification development activities are used to qualify suppliers when items similar to what is required for the AVLIS Production Plant are already commercially available. In this case, it is known that the supplier has facilities and a process in place to make the desired product. The AVLIS organization qualifies the supplier by specifying the desired modifications, obtaining a sample product, testing the sample, and reviewing the data and design with the supplier. This process is repeated until the sample product meets all the desired requirements of a piece of production equipment. In general, multiple suppliers participate in the product midification process so that the final procurement is competitive. Developmental Materials/Equipment. The qualification development activities for developmental material/equipment call for the AVLIS program and procurement personne 1 to (1) jdentify potential suppliers for a product that is not currently comercially available, then (2) interact with them until a piece of production quality equipment is produced. The suppliers undergo the standard evaluation discussed in Standard Criteria subsection as a first step. The candidate suppliers are identified from responses to preliminary advertisements and from the sources and experience of AVLIS program and procurement personnel. The satisfactory candidate suppliers are invited to participate in a conpetitive design/prototype phase. The designs are reviewed and the prototypes are 
tested by the AVLIS program personnel and the results fed back to the suppliers. When the equipment manufacture has been reduced to common practire by this process, the procurements are solicited more broadly.

\subsubsection{Quality Assurance}

The AVLIS Production Plant construction project will have a formal quality assurance program for assuring the performance of equipment and facilities. The AVLIS program a reliability, availability, and maintainability analysis for the production plant will be used in conjunction with the quality assurance plan to determine the construction activities and equipment items that will require special attention to quality control and quality assurance.

In general, the national consensus quality assurance standards already in use by supplier organizations will be considered adequate for AVLIS Production Plant equipment. The exceptions identified during the reliability, availability, and maintainability analysis will be dealt with on a case-by-case basis in the equipment specifications. The special actions required for these exceptions may include material certifications, verification of required test results, equipment calioration requirements, evidence of process control, and training and certification of personnel.

The AVLIS organization and contract manager will assure that adequate funding, manpower, and scheduling coordination is available to implement and track all special quality assurance actions that are considered necessary to assure quality. Examples of the activities that may be required are supplier survei]Jance, first article evaluation, and final approval of inspection hold points. The AVLIS Production Plant procurement organization will institute a procedure for control of deviations, waivers, and nonconformances in accordance with established OOE policy.

The quality assurance for all on-site construction and installation operations for the AVLIS Production Plant will be administered according to the quality assurance program established for the facility in coordination with the the cognizant DOE Operations office. 


\subsection{INTRODUCTION}

A data base is being developed to support directly the Industrial Access Program. This data base--formatted and categorized for the use of procurement managers--has been compiled from the project data, equipment purchase listings, and schedules that have been developed for the management of the AVLIS engineering development and AVLIS Production Plant projects. The purpose of this data base is to facilitate the identification of potential suppliers for the production plant and to promote industrial visibility into the AVLIS program. The Industrial Access Program, Procurement and Supplier Data Base is being updated as new information becomes available.

The manner in which each part of the Industrial Access Program data base has been prepared and how each is being used to support the AVLIS program and the Industrial Access Program are discussed in the following sections.

\subsection{COMMERCIAL AVAILABILITY OF AVLIS EQQUIPMENT}

A Work Breakdown Structure has been developed to define, organize, and identify the wark efforts for the construction of the AVLIS Production Plant. The detailed levels of the Work Breakdown Structure identify the equipment to be procured for the ofant. In this subsection, the organization provided by the hork Breakdown Structure is used to discuss the commercial availability of this equipmels:.

The first three levels of the Work Breakdown Structure are shown in Fig. 3-7. The conventional pieces of the AVLIS Production Plant construction project can be identified from this leve] of detai\}. Commercial availability of the material and services required to complete the Process Building Conventional Facjlities and Plant Support Facilities (Work Breakdown Structure elements 1.7 and 1.4) is not an issue. A large number of companies capable of performing the work in these elements are located in the general geographical area around Oak Ridge: 


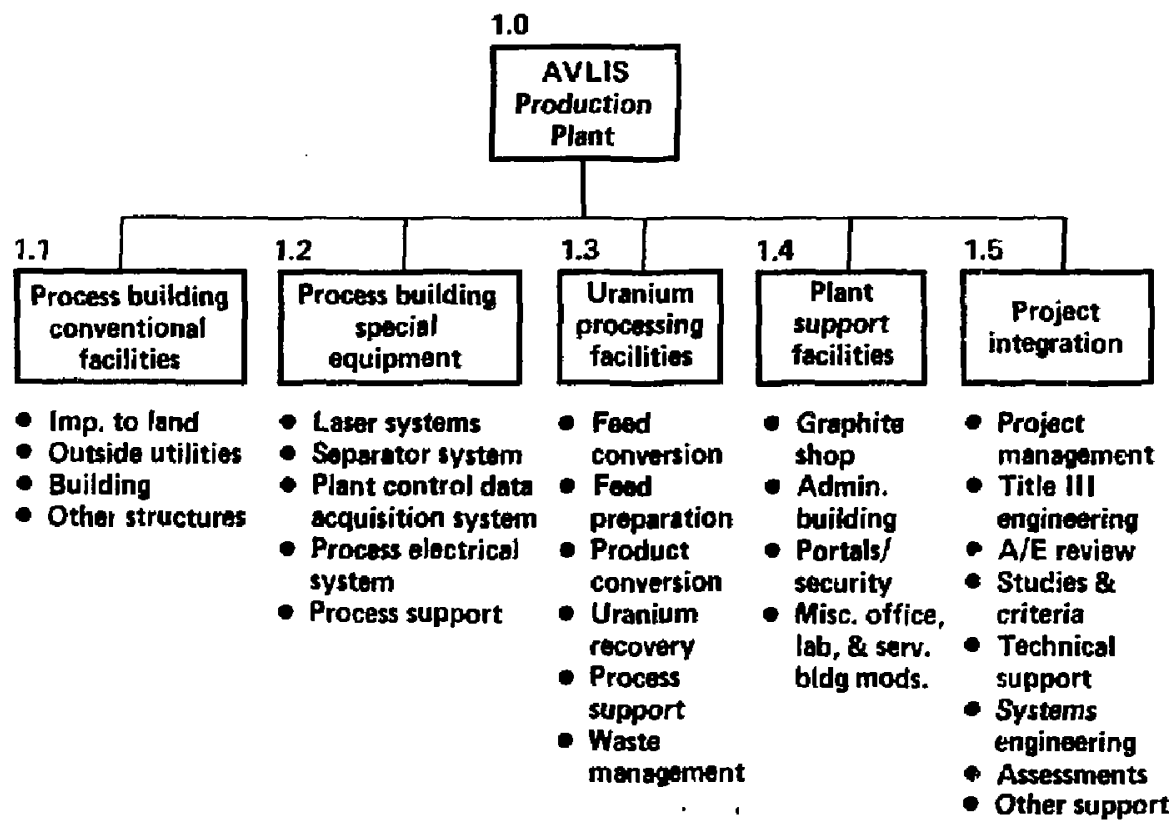

Fig. 3-1. The AVL IS Production Plant Work Breakdown Structure.

The equipment needed for the Uranium Processing Facilities (Work Breakdown Structure element 1.3) is also available from multiple suppliers. A few items, such as the casting conveyor and the furnaces, have been modified from what is used in the steel industry. However, there are multiple suppliers with stee] industry experience that are capable and willing to compete to provide each of these items.

The Project Integration (Work Breakdown Structure element 1.5) will De performed by AVLIS personnel from LLNL and Martin Marietta Energy Systems, Inc. These personnel will be supported by one or more architectural/engineering firms. At present, Bechtel, Stone and Webster, and Westinghouse are providing engineering services for the conceptual design phase of the AVLIS Production Plant.

The only remaining Work Breakdown Structure element for which commercial availability is a consideration involves the Process Building Special Equipment. As can be seen from Fig. 3-1, this element contains the Laser Systems (1.2.1), the Separator System (1.2.2), the Plant Control Data Acqujsition System (1.2.3), the Process Electrical Systems 
(1.2.4), and Process Support (1.2.5). Elements 1.2.3, 1.2.4, and 1.2.5 conta in equipment and software that are either standard off-the-shelf items or build-to-print/build-to-specification items. Multiple suppliers exist to provide all items in these three elements.

Much of the equjpment in Work Breakdown Structure element 1.2.1, Laser Systems, has been developed for the AVLIS process. The items in this element are the Copper Laser System (1.2.1.1), the Dye Lasers $(1.2 .1 .2)$, the Optical System (1.2.1.3), the Instrumentation and Controls (1.2.1.4), and the Refurbishment/Test Equipment (1.2.1.5). Figure 3-2 contains a list of representative suppliers for the key items in each four-digit element with an estimate of the number of capable suppliers that exist. As can be seen from the figure, there are at least three qualified suppliers for each key item; this is a sufficient number to. ensure sufficient supply and competitive procurement of each item.

As with the Laser Systems, the Separator System (Hork Breakdown Structure element 1.2.2) has been specifically developed for AVLIS. The items in this element are the Pod System (1.2.2.1), the Separator Local Control System (1.2.2.2), the Module System (1.2.2.3), and the

WBS

Number

1.2.1.1

System Element

Copper Laser System Laser head (shell; core) Enclosurt

Pulsed power subsystem Gasivecuum subsystem CVL optio Support structures

1.2.1.2 Dye Laser System Mechanical assemblies Dye pumping system Dye laser optics Dyes

1.2.1.3 Optical System

1.2.1.4 Instrumentation and Controls

1.2.1.5 Relurbishment/Test Equipment Optics Test/QA Equipment (Conventional)
Representative suppliers

TRW, Northrup. Hughes, MMES

FMC, Process Equipment; Coors. McDanel, Zircar

FMC, Process Equipment

Maxwell, Physics International, Raytheon

FMC, Process Equipment, Consolidated Vacuum

Spactra Physics, Laser Optics, OCLI

Albary Steel, PST Steel, Bethlehem Steel

TRW, FMC. Spectra Physics

Connors kanufacturing, Remmele. Spoedting

PMI, $\mathbf{8}$ Q, Monterey Mechanical

Spectra Physics, ALE. Laser Sonics

Cyanamid, Eastman Kodak

Spectra Physics, Itek, OCLI

EMC, Honeywell, Quadrex

TRW, Northrup, Hughes

Zygo, Spactrs Physics

Tektronics, Hewlett Packard, Ethe Technology
Potential

Suppliers

20

200; 10

200

10

30

10

100

100

100

100

10

10

10

30

40

10

10

Fig. 3-2. Representative suppliers for the Work Breakdown Structure element 1.2.1: Laser Systems. 
Refurbishment/Test Equipment $(1,2.2 .4)$. Figure $3-3$ contains a list of representative suppliers and estimates of capable suppliers for the key itens for the Separator System. Aga in, a sufficient number of capable suppliers exist for all items in this element.

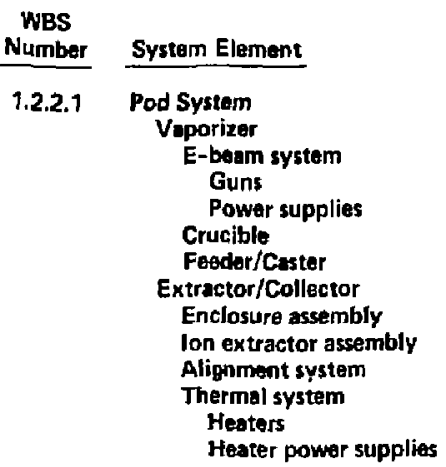

1.2.2.2 instrumentation

1.2.2.3 Module System Vacuum tankage Cooling systems Vacuum syotem Air handling system

\begin{tabular}{|c|c|}
\hline Hepresentative Suppliers & $\begin{array}{l}\text { Potential } \\
\text { Suppliers } \\
\end{array}$ \\
\hline $\begin{array}{l}\text { TRW, Northrup, Lockheod } \\
\text { Lockheed, McDonnell Douglas, TRW } \\
\text { Maxwall Labs } \\
\text { FMC, Industriat Contractors, Process Equipment } \\
\text { Maxwell, Universal Voltronics } \\
\text { Codman, Zok } \\
\text { FMC. Industrial Contracters, Process Equipment } \\
\text { Lockheod, MoDonnell Douglas, Northrup } \\
\text { Integrated Contractors } \\
\text { Ulera Carbon, Gem City, Boeing } \\
\text { FMC, Aorojst } \\
\text { Maxwell, General Electric } \\
\text { Thermcraft, Sunbeam, Ipsen, Abar } \\
\text { General Electric, Westinghouse, ITE }\end{array}$ & $\begin{array}{r}20 \\
20 \\
10-20 \\
200 \\
20 \\
20 \\
200 \\
20 \\
20 \\
100 \\
20 \\
10-20 \\
20 \\
40\end{array}$ \\
\hline EMC, Honeywall, Quadrex & 30 \\
\hline $\begin{array}{l}\text { Chicago Bridge \& Iron } \\
\text { Chicago Bridge \& Iron, Pittsburgh Des Moines } \\
\text { Industrial Contractors, Process Equipment. FMC } \\
\text { High Vacuum Equipment, Consolidated Vacuum } \\
\text { SeO Corporation. American Air Filter }\end{array}$ & $\begin{array}{r}30 \\
30 \\
200 \\
25 \\
100\end{array}$ \\
\hline
\end{tabular}

(Conventional equipment)

\subsubsection{Refurbichment/Test}

Fig. 3-3. Representative suppliers for the Work Breakdown Structure element 1.2.2: Separator System.

In general, the procurement strategy guidelines discussed in subsection 2.2.1.1 will determine the level of integration at which AVL IS Production Plant items will be procured. However, by the time plant procurements are to be placed, some suppliers may be qualified to provide equipment at higher levels of integration. Suppliers interested in bidding on multiple specification packages, or in providing equipment at higher levels of systems integration will be encouraged if their proposals are economically favorable. Suppiiers who have the potential of providing this type of systems integration have been identified for the 
laser and separator systems. Figures 3-4 and 3-5 give examples of suppliers that could provide equipment at higher levels of complexity, as def ined by the work Breakdown Structures levels.

The construction of the Full-Scale Development Facility laser and separator systems is proceeding as planned. The AVLIS special equipment for this facility is being procured using standard procurement procedures and has not experienced procurement difficulties, in spite of an extremely rapid schedule. In addition to prototyping the procurement process for the plant, this activity is generating a complete set of suppliers, including those given as examples in Figures 3-2 through 3-5.

\subsection{SUPPLIER LIST}

The suppilier list contained in this document has been compiled using AVLIS equipment purchase records from October 1982 through June 1984. The companies that make up this list have been entered alphabeticaliy into a computerized database that can be searched and sorted. Each company has been assigned to one or more procurement categories, depending on the type of equipment or service each has provided. Figure 3-6 contains the 1 ist of the procurement categories used. The database file for each company listed also contains the item or service purchased, and the zip code of the company as shown in the procurement record (to indicate geographic location).

Appendix $A$ of this document contains a sorted version of the suppiier tist. The database entries have been grouped according to the procurement categories shown in Fig. 3-6. Figure 3-7 shows a sample page of this sorted list. As the Industrial Access Program progresses into the actual construction procurement phase, the supplier database and the information included for each supplier will be expanded.

Companies that learn about the AVLIS Production Plant project through advertisements and supplier conferences may request that the ir names be added to the list as potential suppliers, in the appropriate procurement categories. To facilitate this access by interested suppliers, a point of contact has been identified. 


WBS level 6 WBS level 5 wBS fevel 4 wBS ievel 3

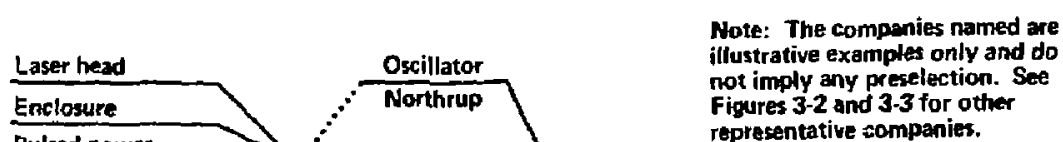

\section{Mechanical equípment}

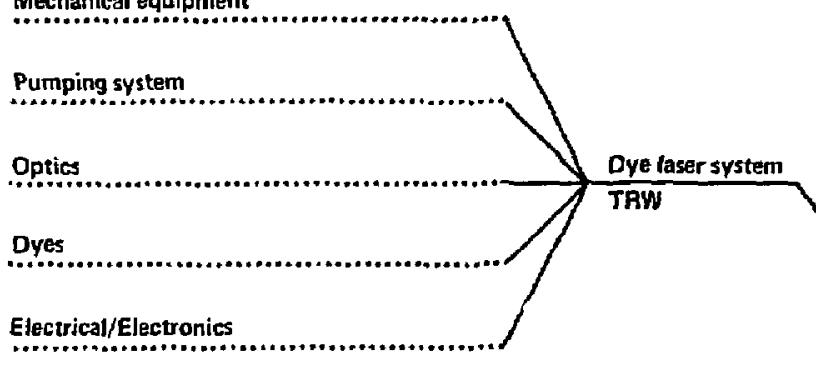

CVL system
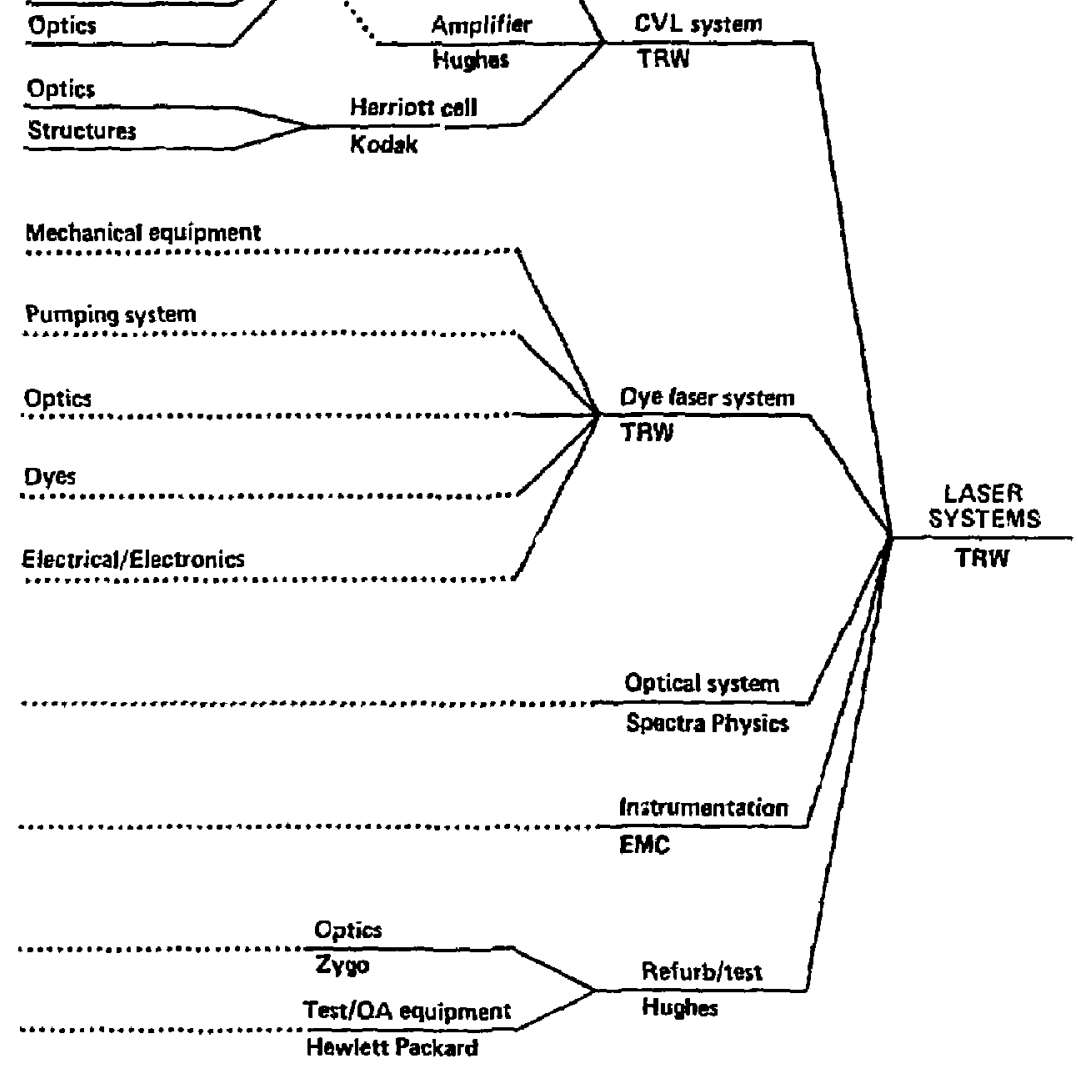

Fig. 3-4. Suppliers may propose to provide equipment at higher levels of systems integration. Examples of companies capable of doing this at the Work Breakdown Structure levels 3 through 5 are provided for the :aser Systems. 


WBS Iowal 6 WBS level 5 WBS Iewel 4 WB level 3

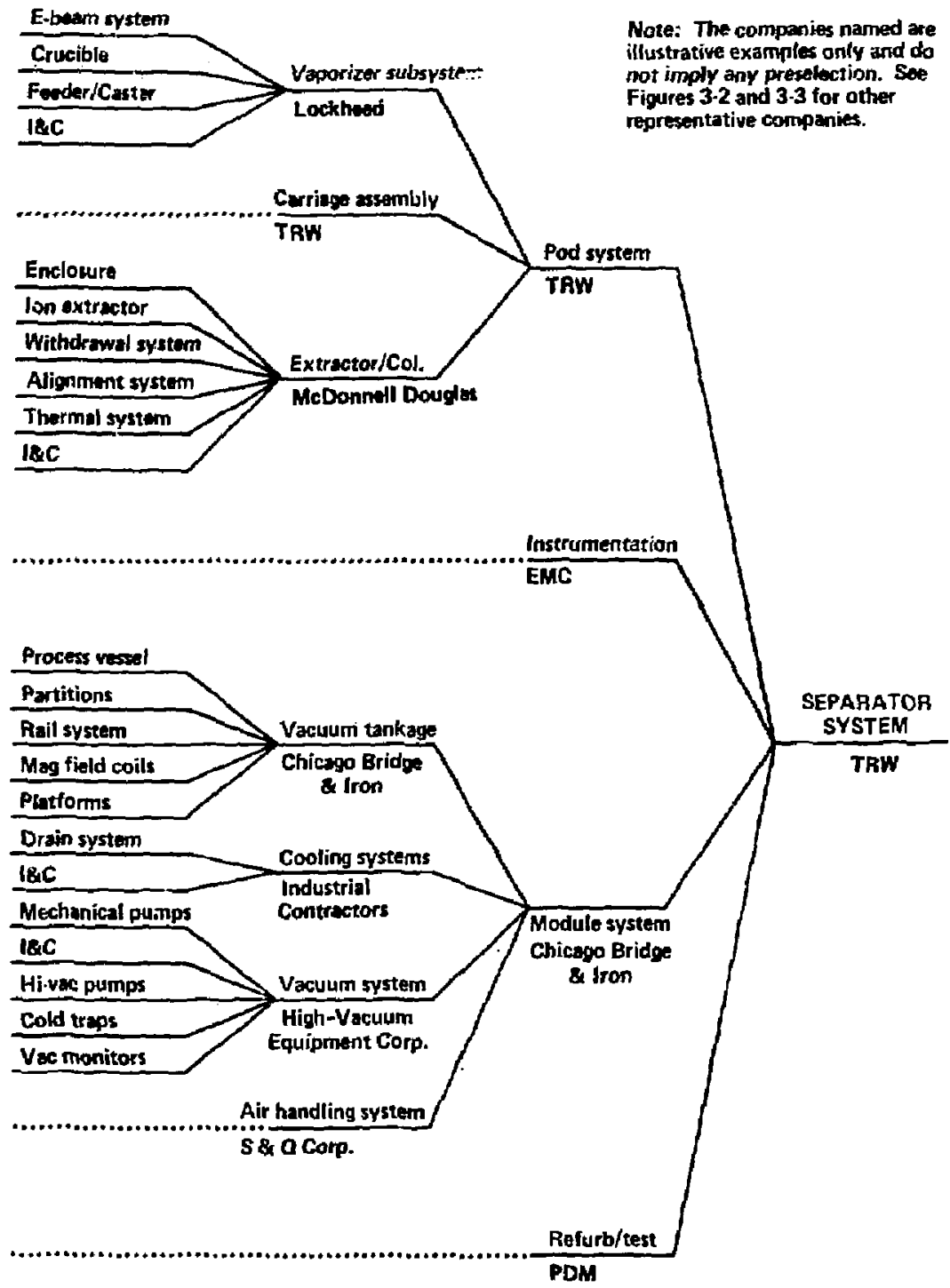

Fig. 3-5. Suppliers may propose to provide equipment at higher levels of systems integration. Examples of companies capable of doing this at work Breakdown Structure levels 3 through 5 are provided for the Separator Systems. 


\section{Procurement Categories}

\author{
Bulk Materials \\ Construction \\ Electrical \\ Engineering Design
}

\author{
General Support \\ 1 \& C/Computers \\ Laser/Optical Systems \\ Mochanical
}

Fig. 3-6. Procurement catagories used in the AVLIS procurement data base.

The current supplier list is included in this document. Updated versions and sorts of the list will be available on request, along with copies of this document and other information contained in the AVLIS Procurement and Supplier Data Base. The designated Industrial Access Program point of contact discussed in the previous paragraph will respond to these requests.

The construction manager for the first AVLIS Production Plant will use the supplier network contained in this evolving Industrial Access Program list to identify companies interested in bidding on AVLIS work. In addition, the list will be ma intained to assist the procurement for all future phases of the AVIS program. Experience with suppliers gained during the engineering development and demonstration programs will be directly applicable to the construction procurement for the AVLIS Production Plant. Additional information on suppliers, including company addresses, will be available through the AVLIS procurement records or from commercially available procurement source books. 
A. JH,LGERS

AERO-5PACE HELDING CO

AEROTECH IHC

AIRTROH

ALL IED CICKP-3AATION

ALPHA GRDUP INC

GIJDOUER LORPDRNTION

ANCENIEUX CORP OF AMER ICA JNL:

APl'I.IED OI ITC'S INC

AR DEL

AFTEL C,UMHUNIIRILAI LUHS CUH

A 11 LO HE 1

AU1ECHI EIFATRLSYGIL-BS L KD

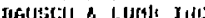

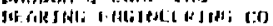

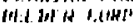

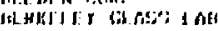

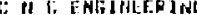

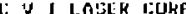

liat:ol. III.

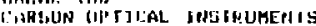

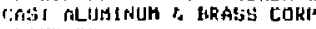

LIABHP teU

CELULLAND CKYSITLS INE

CIJHERF HI I HIC

I:DHHUHWE ALIH SCIEATIFIL EOJR

I:UHI INETTAL IJP I ICS CORP

liONTRAUE'S CODEK' 3 CODKH

CORNINT: GLASS

COUFATR T TILA MACHINE

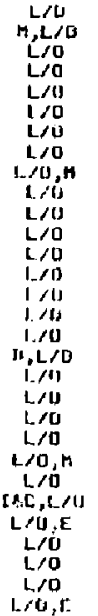

ACHROMAT LENS

QUAD CLAMPS A HASE 4LM OSC]LLATOK

HIRROK MDUNTS

HETCLAS

IEA DSCILLATUP

CENIER LAUELETGTH FITLERS

3" 4 [P'DRW/LENS

I.ASER WENOOW

lkattis niOR

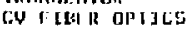

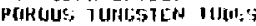

LEN

EHAIIUE I.ASER

TI I tid (ist: Plic

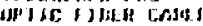

WIIAH I7 TIJbL/C/N LOEE

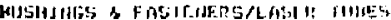

LA!:EL! 11 I KICOK:

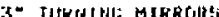

I rUE STUGCUNF/ZE IS's SUE

LOL CASTIHL

TELESCIJPE AJGY/CULLELTOR TrikK

KDP SAHHLEE

POWFR HETERT

IUIA SCHIECE JPUA SUPHI Y, HILLAIIOH \& POIT

CUL 3" WINDUW/SHEAK PL/IIEAM SPLI IILA

TELF,SLOEP

EVL WISDUN BLANKL

OF"T ICE FRLS/L HMEAT AHH
11563

15236

07151

$9.757 \%$

11243

0.3019

$7 \cdot 1+2$

$114: 1 \%$

$1161:-$

4*i:*),

11191

incii:

Phit is:

I.1.1. . .

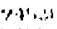

$\because v i n$

II, II

$\therefore \rightarrow$ in:

$x+10$

istiot

ruturit

$4.111 \%$

ine,till:

ind 19

11:By

Tis $3+1$

9403

0,0

Fig. 3-7. Sampla AVLIS supplier list sorted for suppliars of laser/optical equipment.

\subsection{AVLIS PROOUCTION PLANT PROJECT COST BREAKDOHNS}

There are two basic cost breakdowns of AVLIS Production Plant procurements that are relevant to the Industrial Access Program. Breakdowns have been prepared according to the AVLIS Production ?lant work Breakdown Structure and according to the procurement categories defined for the data base supplier 1 ist. These procurement categories act as a cross index of supplier types within the Work Breakdown Structure. The two project cost breakdowns are discussed in the following two subsections. Updated breakdowns will be prepared and added to the Industrial Access Program data base as detailed estimate information becomes available.

\subsubsection{Cost Breakdown by Work Breakdown Structure}

A project cost breakdown has been prepared for the Industrial Access Program data base that corresponds to the third level in the Work 
Breakdown Structure. This breakdown is primarily used to illustrate the major division of AVLIS Production Plant costs. The project cost breakdown for the third level in the Work Breakdown Structure is shown in Fig. 3-8.

\subsubsection{Cost Breakdown by Procurement Category}

A primary goal in the development of the Industrial Access Program data base was the identification of potential construction and operational phase suppliers for the AVLIS Production Plant. For this purpose, it is useful to have a cost breakdown according to the types of suppliers.

Figure 3-9 shows the project cost breakdown by procurement category for the AVLIS Production Plant. This breakdown is being used in the Industrial Access Program to identify uajor supplier types and to comunicate project needs to the suppliers in each category. Potential suppliers for the production plant will bu able to access this data base breakdown to determine the amount of work in their particular area.

\subsection{SCHEDULE}

The schedule for construction of the AVLIS Production Plant is shown in Fig. 3-10. The list of procurements and their planned start dates are given in Fig. 3-11. The long-lead time items are noted. Construction is planned to start in 1987 with special equipment procurements beginning in that year and lasting about three years until 1990. During this period, almost 1 biilion dollars in engineering services, construction, and equipment will be needed. Between 1992 and 1995, an additional 500 million dollars (FY86 dollars) will be required.

The generic system test and deployment logic is shown in Fig. 3-12 with specific dates given for the special equipment broken down to work Breakdown Structure level 4 or 5 in Figs. 3-13 and 3-14. The sequence of activitjes for these items begins with preliminary integrated system and life tests that establish the bas is for the conceptual design and the equipment: The items for which suppliers or products have not yet been qualified have been included in a developmental materials/equipment 1 ist 


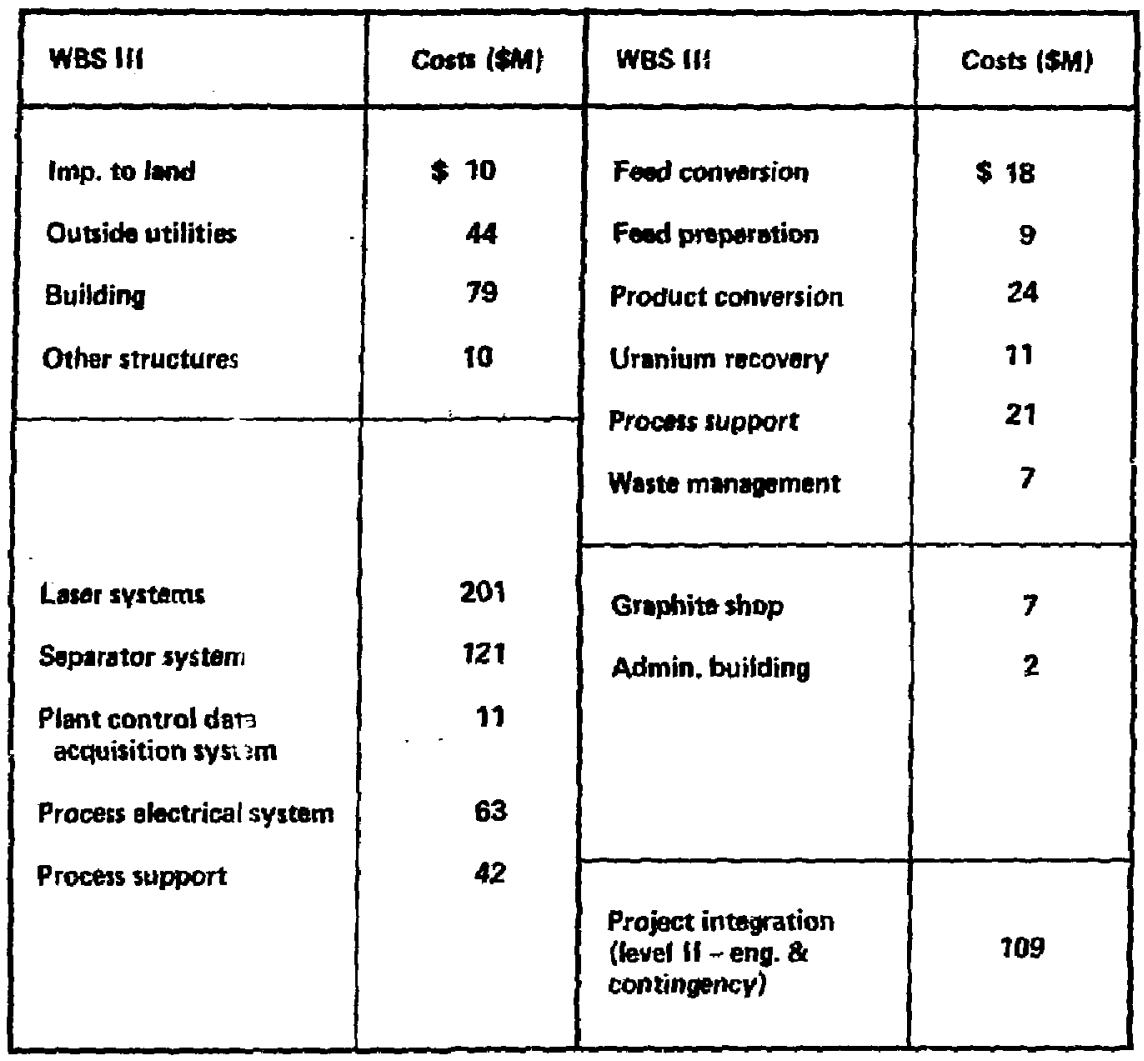

Fig. 3-8. AVLIS Production Plant cost breakdown by Work Breakdown Structure.

prel iminary (Title-I) design based on refined integrated system tests. By this time the full-scale engineering demonstration systems will be completed. The fui-scale systems tests will provide the basis for definitive design (Title-II) and tire preparation of the procurement packages. The procurements associated with the construction of the full-scale facilities will provide the base of suppliers for the production equipme it.

Finally, the aquipment will be fabricated, assembled, installed, activated and the iVLIS Production Plant will start operations. During this period, the full-scale engineering demonstration systems will have accumulated three years of operating experience with plant prototypical 


\begin{tabular}{|l|r|}
\hline \multicolumn{1}{|c|}{ Procurement Category } & Costs (\$M) \\
\hline Bulk Materials & 5 \\
Construction & 105 \\
Electrical & 126 \\
Engineering Design & 109 \\
Genoral Support & 35 \\
I \& C/Computers & 82 \\
Laser/Optics & 201 \\
Mechanical & 122 \\
\end{tabular}

Fig. 3-9. AVLIS Production Plant cost breakdown by procurement catagories.

componenis. For each of the principle subsystems listed in Figs. 3-13 and $3-14$, a list of dates is provided of when the elements were first tested at full scale--engineering test (ET); the date when the element was first tested in the full-scale systems--plant preliminary design ( $P Q)$--complete and definitive design starts, the procurement start date $\{P\rangle$, the duration from procurement start to first delivery, the total procurement duration to last delivery for the construction of the initial increment, and the date of operations start $(0)$ for the system of which that component is an element.

\subsection{DEVEL_OPMENTAL MATERIALS/EQUIPMENT LIST}

As discussed in earlier sections, some materials and equipment required for the AVLIS Production Plant are not routinely available from commercial sources. The supplier qualification development activities for developmental máterial/equipment will result in production qualified 


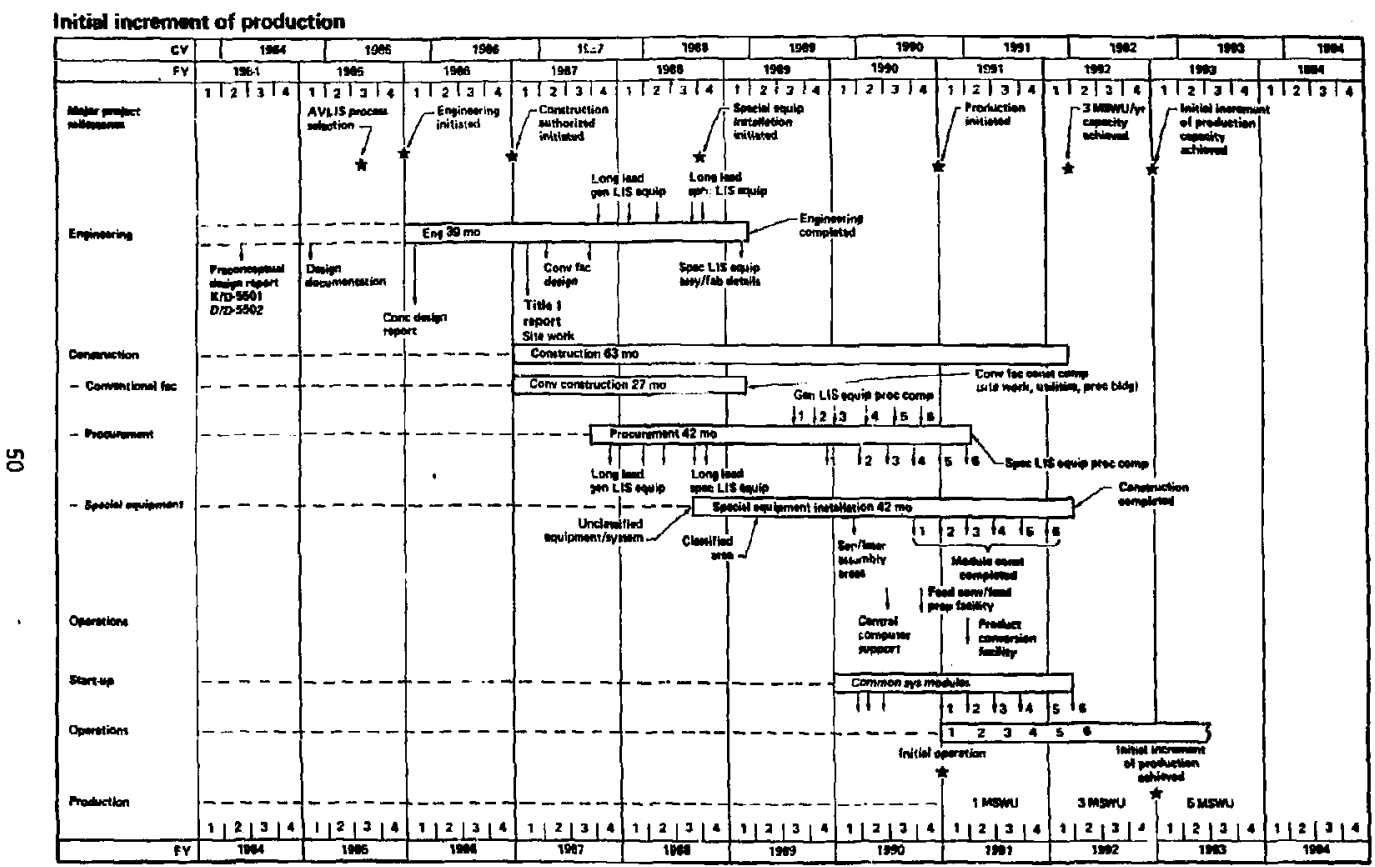

Fig. 3-10. Master schedule for the AVLIS Production Plant. 


\section{Procurement Items}

- Seporator System

- Fecilities a services

- Vecuum chembers

- Refurbishment (astembly) equipment

- Extractor power supplies

- Veporizer power supplias

- I $C$ long lead equipment

- Refurbishment (recyclo) equipment

- Vecuum systems

- Cooling systems

- E-gun /reflux structures

- Corriage assambly

- Chomber internals (rails-liners)

- Transport equipment

- I 8 C panel fabricatione

- Accountability syetem equipment

- Extractor/product collection equipmens

- Laser Syctem

- Facilities 8 services

- Rofurbishment (astembly) equipment

- Mounting support structures

- CVL hesd qual. perts /assemblies

- CVL switch qual. parts/assemblies

- CVL power qual parts/assemblies

- I $\mathbf{c}$ long lead equipment

- Optical components

- Dye laser camponents

- CVL head hardware

- CVI power hardware

- $18 \mathrm{c}$ panel fabrications

- Pointing $\&$ centering

- Uranium process facilities

- Facilities \& services

- Feed conversion - long lead equipment

- Feed preparation - long lead equipment

- Uranium recovery - long lead equipment

- Product conversion - long lead equipment

- Feed conyersion - support equipment/system

- Feed preparation - support equipment/system

- Uranium recovery - support equipment/system

- Product conversion - support equipment/system

- Waste management - equipment/systems

- Balance of plant

- Facilities 8 services

- Plant control - long lead

- Power - long lead

- Graphite shop - long lead

- Cooling system - Iong lead
Issue Dates

87-3

87-4

87. 4

88-1

88-1

88-1

88-2

88-2

88-2

88-3

88-3

88-3

B8-3

88-3

B8-3

89-1

B7-3

87-4

88-1

88-

88-1

88-1

88-1

88-3

88-3

88-3

88-3

$88-3$

88-3

87-3

88-1

88-1

88-3

88-3

88-3

88-3

83-4

88-4

88-4

87-3

88-1

88-1

88-1

88- 1

Fig. 3-11. AVLIS Production Plant procurements and procurement issue dates. 


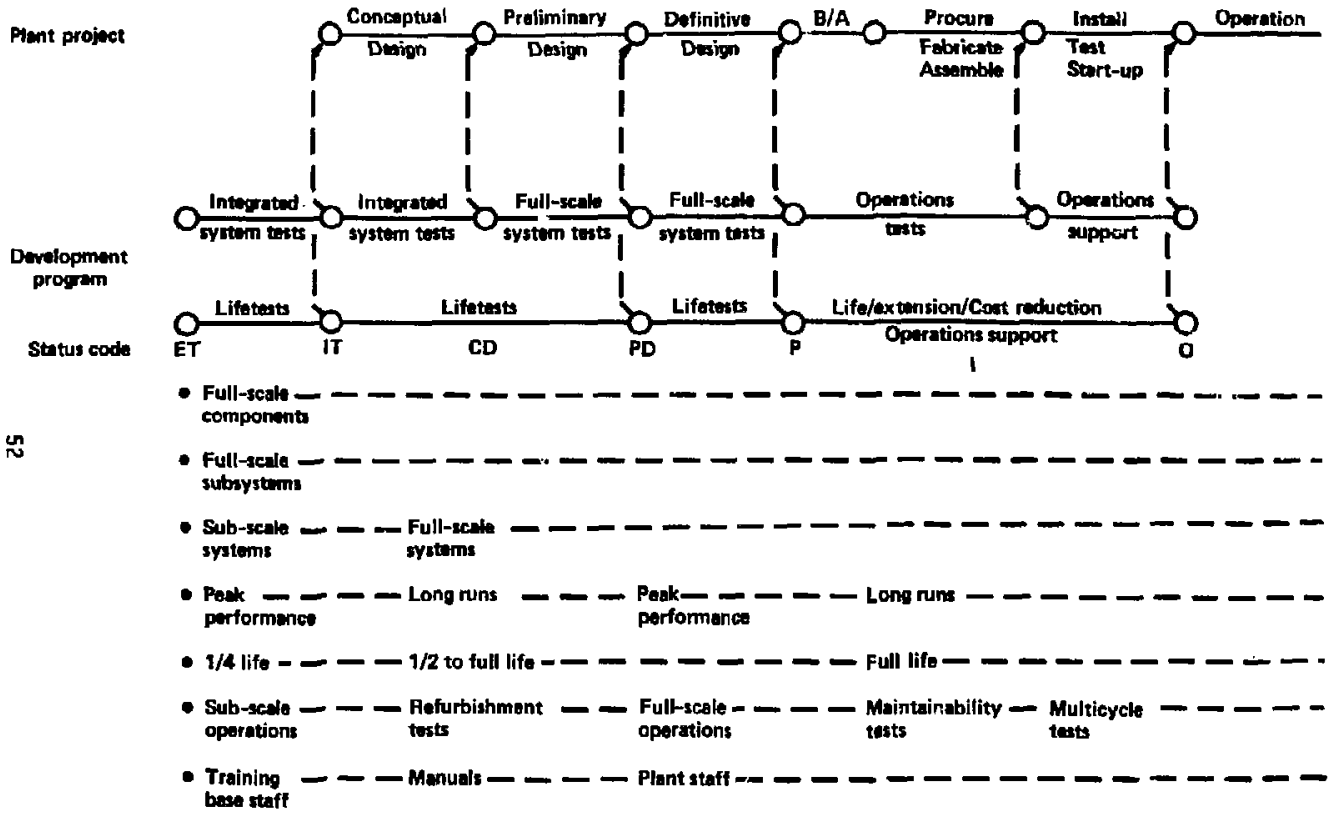

Fig. 3-12. Systems test, procurement, and deployment logic. 


\begin{tabular}{|c|c|c|c|c|c|c|c|}
\hline $\begin{array}{c}\text { WBS } \\
\text { Number }\end{array}$ & System Element & $\begin{array}{c}\text { Test Date } \\
\text { ET }\end{array}$ & $\begin{array}{c}\text { System Test } \\
\text { PD }\end{array}$ & $\begin{array}{c}\text { Procurement } \\
\text { P }\end{array}$ & $\begin{array}{c}\text { First } \\
\text { Delivery }\end{array}$ & $\mid \begin{array}{c}\text { Last } \\
\text { Delivery }\end{array}$ & $\begin{array}{c}\text { Operations } \\
0\end{array}$ \\
\hline 1.2.1.1 & $\begin{array}{l}\text { Copper Laser System } \\
\text { Laser Head } \\
\text { Enclosure } \\
\text { Pulsed Power } \\
\text { Gas/Vacuum } \\
\text { Optics } \\
\text { Structures }\end{array}$ & $\begin{array}{l}3 / 86 \\
3 / 86 \\
3 / 86 \\
3 / 86 \\
9 / 86 \\
1 / 85\end{array}$ & $\begin{array}{l}3 / 87 \\
3 / 87 \\
3 / 87 \\
3 / 86 \\
9 / 86 \\
1 / 85\end{array}$ & $\begin{array}{c}10 / 87-3 / 88 * \\
3 / 88 \\
10 / 87-3 / 88 * \\
3 / 88 \\
3 / 88 \\
10 / 87\end{array}$ & $\left|\begin{array}{c}13-19 \operatorname{mos} \\
13 \\
13-19 \text { mos } \\
13 \\
13 \\
6\end{array}\right|$ & $\begin{array}{c}32 \text { mos } \\
26 \\
32 \\
26 \\
26 \\
18\end{array}$ & $\begin{array}{l}12 / 89 \\
12 / 89 \\
12 / 89 \\
12 / 89 \\
12 / 89 \\
11 / 88\end{array}$ \\
\hline 1.2.1.2 & $\begin{array}{l}\text { Dye Laser System } \\
\text { Mechanica! } \\
\text { Pumping System } \\
\text { Optics } \\
\text { Dyes }\end{array}$ & $\begin{array}{c}9 / 84 \\
9 / 84 \\
9 / 86 \\
1978\end{array}$ & $\begin{array}{l}1 / 85 \\
1 / 85 \\
1 / 85 \\
1 / 85\end{array}$ & $\begin{array}{l}4 / 88 \\
1 / 88 \\
3 / 88 \\
3 / 88\end{array}$ & $\begin{array}{r}13 \\
7 \\
13 \\
7\end{array}$ & $\begin{array}{l}26 \\
12 \\
26 \\
18\end{array}$ & $\begin{array}{c}12 / 89 \\
6 / 89 \\
12 / 89 \\
6 / 89\end{array}$ \\
\hline 1.2.1.3 & Optical System & $2 / 85$ & $2 / 85$ & $4 / 88$ & 13 & 26 & $12 / 89$ \\
\hline 1.2.1.4 & $\begin{array}{l}\text { Instrumentation } \\
\text { and Contral }\end{array}$ & $2 / 85$ & $2 / 85$ & $10 / 87$ & 18 & 33 & $8 / 89$ \\
\hline 1.2 .1 .5 & $\begin{array}{l}\text { Refurbishment } \\
\text { Optics } \\
\text { Test/QA Equip. }\end{array}$ & $\begin{array}{l}12 / 84 \\
12 / 84\end{array}$ & $\begin{array}{l}3 / 86 \\
3 / 86\end{array}$ & $\begin{array}{l}7 / 87 \\
6 / 87\end{array}$ & $\begin{array}{l}16 \\
16\end{array}$ & $\begin{array}{l}39 \\
39\end{array}$ & $\begin{array}{l}4 / 89 \\
4 / 89\end{array}$ \\
\hline
\end{tabular}

*First date starts "first article" evaluation: second date starts full procurement

$\because$ ig. :-13. AVLIS Production Plant laser system procurement schedules. 


\begin{tabular}{|c|c|c|c|c|c|c|c|}
\hline $\begin{array}{c}\text { WBS } \\
\text { number }\end{array}$ & $\begin{array}{l}\text { System } \\
\text { element }\end{array}$ & $\begin{array}{c}\text { Test date } \\
\text { ET }\end{array}$ & $\begin{array}{c}\text { System test } \\
\text { PD }\end{array}$ & $\begin{array}{c}\text { Procurement } \\
\text { P }\end{array}$ & $\begin{array}{c}\text { First } \\
\text { delivery } \\
\end{array}$ & $\begin{array}{c}\text { Last } \\
\text { delivery }\end{array}$ & $\begin{array}{c}\text { Operation } \\
0\end{array}$ \\
\hline $\begin{array}{l}1.2 .2 .2 \\
1.2 .2 .3\end{array}$ & \begin{tabular}{|l|} 
Pod system \\
Vaporizer \\
E-beam system \\
Guns \\
Power supplies \\
Crucible \\
Feeder/Caster \\
Extractor/Collector \\
Enclosure assem \\
lon extractor \\
Alignment \\
Thermal system \\
Heaters \\
Heater power \\
Instrumentation \\
Module system \\
Vacuum tankage \\
Cooling systems \\
Vacuum systems \\
Air handling systems \\
Refurbishment/Test
\end{tabular} & $\begin{array}{c}6 / 85 \\
6 / 85 \\
6 / 85 \\
3 / 85 \\
\\
3 / 85 \\
12 / 84 \\
3 / 85 \\
\\
3 / 85 \\
3 / 85 \\
6 / 85 \\
\\
6 / 85 \\
6 / 85 \\
6 / 85 \\
6 / 85 \\
3 / 85\end{array}$ & $\begin{array}{l}6 / 86 \\
6 / 86 \\
6 / 86 \\
6 / 86 \\
6 / 86 \\
6 / 86 \\
6 / 86 \\
6 / 86 \\
6 / 86 \\
6 / 86 \\
\end{array}$ & $\begin{array}{c}10 / 87 \\
10 / 87 \\
10 / 87 \\
1 / 88 \\
4 / 88 \\
4 / 8 / 87 \\
7 / 87 \\
10 / 87 \\
10 / 87 \\
10 / 87 \\
\end{array}$ & $\begin{array}{c}18 \mathrm{mos} \\
18 \\
18 \\
15 \\
\\
18 \\
18 \\
18 \\
18 \\
18 \\
22\end{array}$ & $\begin{array}{c}42 \text { mos } \\
42 \\
42 \\
42 \\
42 \\
42 \\
40 \\
42 \\
42 \\
37\end{array}$ & $\begin{array}{c}2 / 90 \\
2 / 90 \\
2 / 90 \\
2 / 90 \\
2 / 90 \\
2 / 90 \\
11 / 89 \\
2 / 90 \\
2 / 90 \\
3 / 90 \\
\\
3 / 89 \\
11 / 89 \\
11 / 89 \\
11 / 89 \\
9 / 89\end{array}$ \\
\hline
\end{tabular}

Fig. 3-14. AVLIS Production Plant separator system procurement schedules. 
to focus programatic action on the resolution of the procurement problems they represent. As engineering development activities have progressed, items have been removed from and added to this list.

The current developmental materjals/equjpment list, with summary discussions of each item's application and its associated procurement problems, is provided in Appendix B of this document. Figure 3-15 contains the names of the current items. An up-to-date version of this list is being maintained in the Industrial Access Program data base.

\section{Developmental materials/equipment}

1. Extractor pulser for separator power conditioning (one vendor)

2. Graphite billets for separator module components (size)

3. Machining of graphite collector components for seperator module (vendor clearances)

4. Ceramic plasma tubes for large-bore copper vapor lasers (size)

5. Switching power supplies for large-bore copper vapor lasers (number of vendors)

6. Copper containment for copper vapor lasers (wick lifetime)

7. Optical coatings (reflectivity)

Fig. 3-15. List of developmental materials/equipment. 


\section{ACTION PLAN}

\subsection{POTENTIAL SUPPLIER IDENTIFICATION ACTIVITIES}

AVLIS procurements will employ standard competitive procurement practices. Bidder lists for these procurements will be constructed of interested and qualified suppliers ident ified by several means. Some procurement needs will be adyertised in trade association journals and other appropriate publications. AVLIS technica? and procurement staff may directly contact some companies based on their reputation. Preliminary supplier conferences witl be held to discuss general AVLIS procurement needs. Potential suppliers may themselves initiate contact with the AVLIS procurement organization. Finally, the supplier lists wiil be compiled using the Industrial Access Program data base lists, supplier catalogs, and procurement source books.

This Industrial Access Program document is one mechanism for providing information to interested companies that respond to these solicitations and contacts. Companies that wish to be considered as potential suppliers can fill out a snort questionnaire that covers the information to be entered into the Industrial Access Program data base. In addition, copies of this document will be available from the DOE San Francisco Operations Office and Oak Ridge Operations office iechnical Information Center in Dak Ridge, Tenn.

After the solicitation phase, additional supplier conferences will be held to provide specific information about the AVLIS Production Plant procurement needs to potential suppliers. In general, these cunferences will be held in Livermore, California; Oak Ridge, Tenn.; and other appropriate locations. For some procurement categories there may be both preliminary supplier conferences to orient suppliers and specific conferences to discuss actual procurement details.

Throughout the construction procurement phase for the AVLIS Production Plant, the Industrial Access Program data base will be ma intained. Current copies of Data Base information will be available to interested companies. 


\subsection{ACTION ITEMS FOR PROCUREMENTS REQUIRING SFECIAL ATTENTION \\ 4.2.1. Long Lead Items}

The items needed for the construction of the AVL IS Production Plant that require a long lead time (due to materia) availability or other factors) have been identified as part of the conceptual design phase. The procurement of these items is scheduled to allow adequate time for delivery to meet AVLIS Production Plant project milestones. The timing of these procurements is given as milestones in the project procurement schedule shown in Fig. 3-10 and included in the Industrial Access Program data base.

\subsubsection{Developmental Materials/Equipment}

Every attempt is being made to conclude the developmental procurements, discussed in section 3.6, and surmarized in Appendix B, during the engineering demonstiation phase of the AVLIS development program. Preliminary solutions are currently available, but these do not yet fully meet the performance objectives for the final production facility. If fully qualified suppliers and products are not developed before AVLIS Production Plant procurement begins, acceptable quality items that are avaitable will be used. In these cases, in particular, product improvement activities will continue into the operational phase for eventual installation during refurbishment.

There will be ongoing efforts to stimulate all AVLIS Production Plant suppliers to continue to improve facility efficiency through product and technology advances. Because of the routine recycling of equipment during plant refurbishment operations, these improvements will be integrated into the AVLIS Production Plant. The operating contractor for the AVLIS Production Plant will coordinate the program to stimulate and integrate product advances. 
Some elements and configurations of AVLIS equipment are restricted by classification at this time. Ouring the development and demonstration phases, suppliers without clearances have been used to provide components that are not classified. These components have then been assembled by AVLIS personel into the final, classified configurations. If a supplier can make a sufficiently favorable proposal (f́rom an economic standpoint) to provide an entire assembly for the production plant, the AVLIS program will seek clearances for the supplier so that access to the classified technoiogy can be granted.

\subsection{TECHNOLOGY TRANSFER ACTIVITIES}

\subsubsection{Improvements in Existing Technology}

Satisfaction of the performance requirements of equipment for the AVLIS Production Plant will result in technology improvements in several fields. Trese improvements are generally in the areas of materials, component and system reliability, and operational liretimes. The AVL IS technical staff is working with the suppliers, via the modified product and developmental materizl/equipment qualification development activities, to develop these improvements. Therefore, the transfer of some technological advances will be a direct result of AVLIS Production Plant suppliers participation in the project procurement process.

\subsubsection{Other Applications of Separator/Laser Technology}

The design of some AVLIS process separator subsystems was adapted from tecimology already in use in commercial metal refineries and processing plants for such materials as steel, tungsten, and aluminum. The advances made in this technology, therefore, can have direct application in these industries. Companies that wish to apply the metal handling processes developed for the AVLIS Production Plant will be encouraged to do so, particularly if they are AVLIS suppliers. 
Conferences will be arranged with these companies, and design and performance information made avallable. Every effort, within classification restrictions, will be sisde to provide all necessary process information to interested industrial groups.

The Allis development program has caused significant advances to be made in the area of laser technology. The reliability, lifetime, power. and efficiency improvements in laser components resulting from the AVLIS program will both directly aid existin- --lications and stimulate the development of new applicatiomvements in technology will be made available to all

if acceptable after, .er:sted in their application, issification issues.

\subsubsection{Industrial Photo-Chemical Processing}

There is potential for the use of lasers for pnoto-chemical processing. Rare-gas halogen lasers have already been used to produce vinyl chloride monomers. Photo catalytic processes may be further developed to produce other similor chemicals from simple feed. Lasers may prove to be economical in eliminating calalytic poisons such as $\mathrm{H}_{2} \mathrm{~S}$ during the production of methanol, methane, glycols, and other hydrocarbons. Finally, more speculative applications are possible in the contral of cambustion particulates, crystal and powder chemistry, and laser-induced biochemistry.

\subsubsection{Application of Laser Isotope Separation in Other Areas}

The AVLIS process can be used for several military- and energy-related applications involving the separation of isotopes of uranium and plutonium. One particularly fertile area is in the removal of still useful materials from radioactive waste.

AVLIS can also be used to separate the isotopes of other elements. One example is the interest that has been expressed in the enrichment of common mercury. Increasing the mass fraction of $\mathrm{Hg}-196$ can substantially improve fluorescent Tamp efficiency. The AVLIS program is continuing to investigate these applications while supporting their pursuit by private industry. 
A detailed discussion of the privatization of AVLIS technology is beyond the scope of this Industrial Access Program document, and is discussed in other AVLIS progran documentation. However, the private industrial application of AVLIS, whether for uranium enrichment or ocher purposes, represents the ultimate achievenent of technology transfer. The AVLIS progran will strongly support the level of privatization activities that are sanctioned by the Federal government. 


\section{APPENDIX A: INOUSTRIAL ACCESS PROGRAM SUPPLIER LIST}

This Appendix contains the current Industrial Access Prografi Procurement and Supplier Data Base supplier list. The list has been sorted according to procurement category: (1) bulk materials, (2) construction services, (3) dato processing equipment, (4) electrical/ electronic (5) engineering design services, (6) general support equipment and services, (7) instrumentation and controls, (8) laser and optical systems, and (9) mechanical. The companies listed are the actua? suppliers of the AVLIS program at LLNL from the period of October 1982 through June 1984. 
ALCHEMIST

ALDRICH CHEMYCal LO INC.

ALFA PRODUCT

ALL IED-SYSCO

ALPHA PRODUCIS

AMAX SPECIALTY METALS CORP

AHERILAN BOA

AHER I CAN STEEL

ASHLAND CHEMICAL. CO

BAYFLEX PERLYORATING CO

ROLT TECHAIC

\section{BOYD IADUSTR}

LAEORATORIES INC

EURT BRICKER INC

CADYLLAC PLASTIC CHEH CO

CALIFORHIA TERFORATION

CARBORUNDUM :OO

CASTLE PLAETICS

CERMANICS MTL

CITY HIRE CLOTH INC

CDLDR SHDP INC

COLUHEIA ORGaNic CHEHICALG INE COMLEH LCAL PLASTI

COOHS PORCELATN

COPPFR \& BRASS SALES INC

CTRTH PLASTICS

CTC DRGANICS

CURC

DELTA METALS

DIELECTIC SCIENCES

DU PUNT CO

DYHASIL CORP OF AHERICA

EASTHAN KODAK

EIR PLAST TC

ELECTRICAL SPECIALTY CD

ELECTRONIC SPACE PRDDULTS IME

ERG IHC.

ESEO CORP

FAHSTEEL METAL

FIBER MATERIALS INC

FISHER CONTROLS I

FLYNA \& ENSLOW INC

FRAHKEL CDMPANY JME
FUTUIRA TITANIUM CORP

GATEUAY WIRE CALLE

GENERAL MAGNAPLAT

GRAPHITE MACHINFD I'RODUCTS

G1E: FYLUANIA

GLYYUIN ALLUYS INC

H L.AOSS CU

$\mathrm{HI} L \mathrm{TI}$ INT

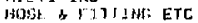

ETHYLENE CLYCOL

METHYL SUL.FUXIDE

TRON ERCMITE

YLTTERRIUM, INLOTS OF

MOLYBDENUM, LHEETS \& BARE

FLEX CONDUTT /METAL HOSE

STEEL COLUANE/BLACK PIPE

FLEX HOSE

PERFORATED IANTALUM

TUBES

PACKING MATERIAL

Z-METHOXYETHYL ETHER

COHDUCTIVE CUATINGS

DELRIN DISC/LEXAN SHEETS TUBES

IIOROH NITRIDE RDDS

PEDESTAL/TUAING

BRAIDED SLEEVING

TI UIRE CLOTH

BRUSH THINNER

HEXACHLOKO PROPANE

PLASTIC

LAMPS, MINT -COOL

ALUMINA TUEES

COPPER TUBYHL

PLEXILLALSS, GHEETS

HEPTACHLOROPRTPANE

STEEL PUIRL.ING/GALYANIZED RODFINC

COPPER PLATES

CABLE ASSYS

KAPTON FILM/SAMPLE KIT

HLANKS, 517.5

RHODAMINE $101 /$ PROJECTOR/FILM, PHOTU

PUC KOD S THET

GLASTIC, GHEET \& ANGLES/SLEEUES

PONDER, MOLYEDENLM HETAL

TR ITON GRAPHITE

WELD FIITIEGS/ TUBES \& FITTINGS

TANTALUH FQIL

FIBERFORM CEMENT \&OARD

SPACERS A ASUESTOS

MOLYBDENUH LLUTTH

SHEET TITANIUA

TITANIUH FAEIENERS

CAELE

LASETK MUUNTS/COATIMES, HI-T-LUE

POCO GRAPHITE.

TUNGSTEN RODS

PIPE, SEEMLESS

TUNGSTEN RIBEONS

FASTENER G/SHOI" DR ILL

SLECVES \& NUT?

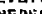

95050

B0401

9480087

95050

30315

94710

94544

(1) 101

19898

0800

94563

95035

$\$ 408$

90035

UNK

746013

60064

04005

94401

94107

18020

91359

94610

43003

90242

94010

प11507

41207

94577

$945 \% 7$ 
ICN $K$ \& $K$ LABS

INSULATIDN MATER IAL

$K R$ ANDERSON CO INC

KULITE IUNGGTEN CORPORATION

LEAD PLASTIO

LEED PLASTIRG CORP

LUIEK METALS CORP OF NIIRTHERN CALIFID

MATERIALS RESEARCH CDRP

MELKES MACHINE

METAL BE'LLOW CORP

METALMART

METRON INC

MUNTEDISON USA INC

MUSSER ASSOCIATES INC

NANMAC CORP

WF. IJNAL AERASIVES

NATIDNAL-STANDARD CO

MATICNWIDE ADHES:UE PRODUCTS TNC

NAT -DAK EO OF CAL.TFORNIA

NCR CORP

NL INDUSTRIES CO

NUCLEAK METAL INC

DUERLOOK INDUSTRIES (SAPUN LAEORATD

OZARX MAHUNINE CO

PHILIPS ELELTRONIC INSTRUMENTS IWC

PITTSEURE-DES MOINES STEEL CO

PLANT INSULATION CT

PLAsTiC SALES IAC

PDCO GHAPHITE INC

PULYTER DESTGN

PORT PLASTIC INC

PULBR ITE COHPANY

REMBAR COMP INC

RESEARCH CHEMICAL.

RHENIUH ALLOYS INL

SAES GETTERS/USA INC

SAH JOSE DELTA ASSUC INC

SAN JOSE SCIENTIFIC CO INE,

SAN LEANDRD ELECTRIC SUPPLY CO

SATURN INIUSTRIES INE

SAWYER RESEARCH PRODUCTS INC

SHERWIN WILLIAMS

SHIEl.DING TECHNOLGGY-WEST INC:

SPECTRA GaS IND

SPEX IHDJUTR IES IKE

STACKPQLE CORPORATION

STANDARD WIFE \& CABLE CO

HOSE ASEYS A FI'TTINGS

F ASTEKERS, TA

WRE CLOTH, TITANIUM

WI SUET NUTS

OCTACHLOROי R OP ANE

SJLILA

BILJCONE FLUTD

JUHGSTEN SHEETS

MACOR RODS

MACOR SHEETS

PLATE, ALUM

CLUPPER RUDS; ANALYSIS IF Y SAMFILL'S

FEKRU SEAL

BL:L LWS 6"/FLEXIOIGE

NILKEL, INCONEL

WIRE, FURE IRUI

FOMELSA OIL

INSULATION/TAHLE HOIST

OXIUI, CERAMIC INSUL

INCONEL UIRE

PLASTIL GEALE

LACDLECR

TATALUM FOIL

RODS DEPLETED URANTUM

UEPI.ETED URANIUM METAL

NEODYMIUH INGOT'S

HYOROXYGUINOLIN

MOFG GAS

HOL HODENUM PLATESX-RAT LEENER ATOR

METAL PIPE

FUAMGLAS

ACRYLIC SHEETS

COLLFCTOP. HEATINE ELEMIN, /SHEE T GRAPHI TE

WATIER COLL ERREAK

FREUN, CANNISTE'S

TANTALUM \& TITAILUM/TURESTEN

GADCLINIUH YYTTR IUM INGOT:

TUFLLHE, MOL YUDENUM

WIRE, LUMA 12 \& 20 MICROANS

REFLECTOR TURES/INSULATIOW/ MALOR ROD:

VACUIJM PUMP/PUMP UIL

HI TEMP. WIRE

1 LEES-TUNGSTEH

CULTURED CRYSTAL. QUART'2

\section{PAINT}

SH1ELDING MATERIAI

I. XCIMER GASES

LAE GLASSWJARE/URANIUN : $X$ NITR

TORR L.UHE

TIDROLDS

CAHLE, SHIELDEI

94595

12003

94086

9060

ทUบ?1

9021

950501.

91733

9131

90401

$07 a 2$

90570

44415

9005

02146

12205

$0+742$

08894

74119

91604

95201

乌46́́

04124

26234

ט2370

95131

10522

65063

44036

04906

95050

4511 ?

$4457 \%$

12534

44094

97701

071014

9505:

43103

1'งค2? 
STRUERS INC

TELEDYNE (WAH CHANG HUNTSUYLLE) THERHAL AMER ICAN FUSED QUARTZ CO TIMCD MFG CÖ LHC

TRAHS-TECH

UNION CARTIDE CORPORATION

UNIDUE WIRE WEAUING LO

UNITED FLASTICS CORP

VAC-HYD CORP

WATER UORKS MFE

WESTERN FLUIDLINE PRDDUCTS INE

WILAAD GLASS CO IHL

WILSHIRE FDAM PRDDUCTS

ZIFPERTUEINE: CO

ZYP CDATINGS INC
SILICON CAREIDF

THES SFECTRASIL, I" THLC

HI TEYP WIRE

FERRITE TOROI

PIPING

BDRON NITRIDE

TUNGSTEN SCREE

PLASTIC TUBES

HONEYCOHE TA/RRAZE EFCK"T

STEEL PIPE/STOQL

HOSE

TUBING

DAH, ACQUST IC

TUEIHG

PAINT

44136
55066

07045

91303

지응

9ง5nA

OUBDE

07205

74621

01923

95401

95691

68310

90745

90040

37830 
UENDORS - GERSTEUCTION

A \& I TRUEK ING

AQEL CUSTOM EXTE TIORS

ALL STATE COHSTI.JCTION CO

ALLIED METAL FALA ICATDRS

AMCUN CONSTRUCTIDN

AMER ICAN HEL"HANICAL BIGTE CRANE

BITCO

IROUKMAN CO INC

BUCKLES-SMITH ELECTRIC CD

EUJFFALO FORGE CO

CHAPEK CONGTRUCTIDN

CUBBLE-KIBBE LLASS CO

CONSTRUCTION

COUSINS CONGTRUCTIUN CD

DANUILLE HOME IMPROUEHENT CENTER

DEETZ CONSTIULT ION EO INL

E F PLUMEIUS

ELECTRICAL POUER PRODUCTS

ELECTRONII: MANUFACTUR IHG SERUICE

$F \& H$ CONSTFUCT

FANFA-MULLOY

F'ORDERER CDRNICE WORKS

FURMS SURFACES

GEORGE E HAGKER YNC

GEORGE $F$ SCHULER INC

GILEERT, E.K.

GRANITE HILL \& FIXTURE CO

HAEENICHT \& HOLLETT

\section{HEATHORN}

HICKS-INELE CONGTAUCTION

HOTWATY INC

IHDUSTRIAL ASPHALT

INDUSTRIAL

IATERSTATE DOUR SALES

I A CR ALIF URD CO

JTM HANUFACTURI ING CO INC JACK DYMOND CO

JOHNSUN CONSTRULTION CO

KENDALE PLASTILS INC

KNICKEREDCKER

LASERLINE

LOCKLOOD GREENE

HEMORY SPRINKLER

MODULATRE INDUSTRIES

MORGAN FABRICS CORP

NESS ELECTRIC CO

NORMAN 5 WRIGHT EQULPRENT LO

DAKLAND FENGE

DUERAA

PAEIFIE ROLLINE DODI CO
CUNCRETE PUAPIHL

QUIILDING EXIE:4tSTH

FRONECT SUPPIRT , GENERAL LUNTRACTOR

CORPURATUN YARD GRATING

FAE A INGTAL.. FIWNILES

TLLL ALOMINLA ALNINGS

EQUIPMENT RENTAL, L.AUJR, BEFUTCE

SANURLAST SHTERIOK SUGF NEES to REPAIR

DELIVER \& INETALL FLLIR $940 \mathrm{CB}$

ACCESS ENCLOSURE

FAN DESIGN \& FALKTCSTE

FAU, FINISH \& E.MGRMUE PANEL. 945\%\%

CONSTRUCTION

STAIR GIAGG, JRESTALLATIUN

WALL CUWERTHLS 9450\%

PROJECT SHRPGRT, GEIERAL TONIRACTOR 37 KU

CRADING, ILDC.

INSTAL1. STEEL DOOR

INGTALL WIREWISA IN AD

ITLEG 333

FOUNURTIONS WOR STEEL CUNSTRUCTIOH

DOOR FBAHESTHETAL LEOLES

FACING PANELS

PAITT WALLS HLDG 992

CONCRETE

FAI JEL INSTAL CORINETS

SIDE WINDCWS $\quad 94116$

SECHANTCAL CONSTOUET COH

HECHANTCAL CONSTRETRUN

MLCHANICAL COHSTRUC I YON

INSULATIUN COHBTRUCTON

AGHAL T RICH

$\begin{array}{ll}\text { ASFHAL RICK } & 94566 \\ \text { HODLP,AR COHPLEX, T1\%33 } & 91761\end{array}$

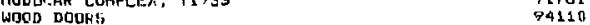

$\begin{array}{ll}\text { WDOD DODFW } & 94110 \\ \text { CEHENT SAUEREISE } & 90009\end{array}$

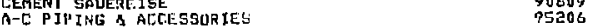

ALOUSTIC PANELE

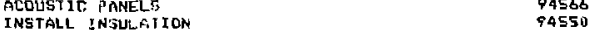

INSTALL INSULAFIION

FLNOR 7ILES 90753

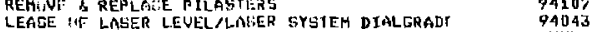

LEAEE "IF LASER LEUEL/LAEER SYSTER DIOLGRADP

STH 4 HKL RISER: 94553

WHA JAKLER RISET:

WALL COUERING I-AERICS

ELEETRICAL_ CONSIRUCIIOH

DIFFISUER';

FEMEING

PROJECY TUPPDIR1, GEMERAL CINTRACTIH 94905

ROLI.INL, DUORE 
YENDURS - CONSTRUCTLON

COHPANY NAKE

CODE

PARTITION SPECIALITIES INC PENHALL INTERNATIONAL

PLASTIC NORKE INC

PLFSATTON ENGTE

PLEASANTON ENG

PORTOLA VALLEY

PSP

OCON INC

RED FEATHER CONSTRUCTIBN CO

FEID \& TARTCS ASSOCIATES

ROADRUMHER GLASS CO

ROEHLEN INDUSTR IE

RPH ERECTORS IN

RI ST CONSTRUCTIAN CO

RLTH \& COING IND

RCOTSMAN MUBILE LEASE

GIERRA CRANE \& HOIST CD INE

GDNO-CEIL CD

GTRATFORD IN

SUNSET ALUHINUH PRODUCTS

GYSKA \& HENNESGSEY

TORRES ELECTRICAL SUPPLY CO INC

UNISTRUT NORTHERH CALIFORNI

a WITION COWSTRUCTION CO IHC
C INSTALL RAISED FLOORS/TARTITIOH GLASE INSTALL RAISED FLOORS TARTITION GLASE
CUNCHETE SAW CUTTING S LAHOR WINDOW SUR-ASEYB $\quad 94710$

CONSTKUCT ISDLATION SLAE

CONCRETE

RELOLATE TREES

STEEL SUPPORTS TAB

STEL SUPPORTS FAR

SITE PREPABATLON

FLOOR INE

FOUNDATIDN S/OR STEEL CONSTRUCTION

PRDJECT SUPPORT, ENGINEER ING SERUICES

TRATLER FUR CONOTRUCTIDN NEEDS

AR CHITEETURAL A OO INTERIURS CONSTRUCTION

HOLLOH METAL DODRS

CANOPY, FAB \& INSTALL

ENGINEER IHT SERUICES, ENGINEER 2NE SUPPDRT

ELECTRICAL CDNSTRUCTION

RAISED FLODP

PROJECT GUPPORT, GENERAL SUPPORT

WALL PANELS TRIM 
VENDORS - ELECTRICAL

AAC TNC.

ABACUS ELECTROHICS CO INC ACOPIAN CORP

ACIION INSTRUHENTS CO INE AIRPAX CORP

ALAMEDA ELECTRIC SUPPLY CO ALL-TRDNICS INC

ALPHA-TEK

AHERICAN SEIENTIFIC FRODUCTS

AKIS PRODUCTS CORP

ANALOC DEUICES INC

ANIXTER-SANTA CLARA

ARROW ELECTRONICS INC

ASTRO SEAL INC

AZ INDUSTRIES INL

BARKEA \& WILLIAMSON INC

BAY ASSOCIATEE INC

BERTAN ASSOCIATES INE

BRUEL \& KJAER INSTRUHENTS INC BURR-BRDWN

C \& G PRECN

CADDOCK ELECTRONICS IHC

CALE⿱丷 MANUFACTURING CO INC

g. CAMPEELL 4 G

CAPUER

CARUER SUPPLY INC

CATUR SUPPLY INE

CETA CORP

CITY COR TOE A

CITY TOOL-DIE \& MFI CO

COMMONWEALTH SCIENTIF IC CORP

CONDENSER PRO SCIENTIF IC CORP

CONDOR D C POWEER SUPPLIES IHC

CONAER HFG CO INC

CONSOLIDATED ELECTRICAL DIST INC

CONTROL MASTER PRODUCTS

CONUERTER CONCEF TS INC

COPER LASERSUNICS INC

CQVENTRY TOOL MACHINE

CSI TECHNOLOGY RCAPACITORS DIU

CUSTOM ELECTALNICS CO

\section{D'ARCY}

DALE ELECTRDNILY INC

DEERFIELD LARORATORY

DSI CAPACITUR

DUBL.IN MULTILAYER INC

DUCDHAUN INCORPGRATED

DUNIWAY CORP

DUNIWAY/STR IKER

DURAMAGNETIC

DYSON INDUSTRIES

$E-Z$ HOOK

EGAT INC.

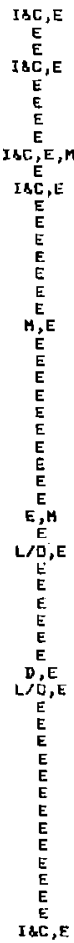

CURRENT MONITORS

CAELE/TRANEFURMER
POWER MODULE/SUPPLY

ACTION INSTR MAT/ISOLATE TRANSHITTER

CIRCUST HREAKER 95051

RELAY 94545

RF FILTERS 11590

IIRIDGE, HOLLOU CATHDDE 92020

TEMP CONTROLLER/LAMP CATHODE/UAC DUEH/ATOHIC ABSDR QADBG

CONHECTORS

AMPLIFIERE, INSTRUMENTATION OIPERTIONAL T5I2E

SHIELDED CAELE 95132

IRANSFOR MEFS/CHIPS, PROGRAMMIALLE

COAHHERHHUL TPIN

INDUCTORS

CABLE, SHIELDED CONTR

BERTAN HUPS/PUWER SUPPLY

UOLIACE CONUERTERS

E-BEAH GUN

PDNER SUPPLIES

CIRCUIT EREAICES

RESISTURS

TRANSF ORHER 3

TRANGF OKMERS

HU CONHECTORS

POUER SUPPLY

ELECTRODE ASGY /LASER SUPPORT

REPAIR PULSE AHPL TF IER

TON COURCE/PUR SUPPLY, MILLATRIJH A PARIS

CAPACITOAS

CAPACITOAS

POWER AMP UESGELS

DOOR LATCH KLTS $/$ POWER CONNEC TORS

BELDEN CAKLE

POWER SUPPLIES

DES CONTPAETPPONER SUPPL' SWTTCH \& COUAPLAS

OPTICS PKG LLINEAR MAP

RESISTIRS

CAPACITORB

STEPPER MOTOR

RESISTDRS

TRANSFORMERS

CAPACITORS

RELAY-DRIUER INOARDS

GENERAL HARIJWARE

REBUILT IDN SOURCE ASS

REBUIL \& CLEAN IUN SOLYCE AGSEHELY MAENETS

ELECTRODE ELERERTS

TEST CL.TP IUMPERS

THYRATRONS

\section{7}

92805

75125

95119

9,2507

94010

94010

9,2025

45403

4403
82633

92633

94041

9500

0690

22314

94040

93020

85201

94080

94518

53954
94041

94041

95035

42025

75126

74621

68602

94022

92025

89566

8000

94303

91303

43560

89204

71006

99086 
VEHDORS - ELECTAICAL

COMPANY NATE

ELECTRICAL DISTRIEUTORE CO

ELECTRCN TECHNOLOGH IMC

ELECTRONIC DLUTCES INC

EL.ECTRONIC MEAGUREMENTS INC

FERROXCIEE

G 1 COOKE ASSOCIATES

GENERAL ELECTR IO

GIBSON ELECTRICAL SUPPLY CO

GLOBAL EQUIPNEMT CD

GRAT ELECTRIC CO INC

GRAYBAR ELECTRIC CO INC

GULTON INDLSTA IES I

HALL- EAK EIECTROHICS CO

HALL- ARK ELECTRONICS

HEINEMANH ELECTRIC CO

HIPOTROHICS INC

HOTROHICS INC

HUE IN INDUSTRIES INC

HUNTING TON LABOR ATUR IES

INDUSTRIAL ELECTRIC MANUFACTURINE

INDUSTRIAL ELECTRONIC ENG IRC

$\begin{array}{ll}g & \text { INSULATION EUPFLY CD } \\ 0 & \text { INTRONICS INC }\end{array}$

ION PHYGICS CORP

ISOLATIOH DESIGN INE

ITT CANND

ITT ELECTRON TUEE DIU

ITT POHDMA ELEGTRONICS DIV

93 ASSOCIATES

JOHN FLUKE MFG CO INE

IEPCO INCORPORATED

KIERULFF ELETTRONICS

KILOUAC CORP (DOW KEY DIU)

KINGS ELECTRONICS INC

LAKE SHIRE CRYOTROHICS

LAHEA PNYSIK

LASER MAGNETICS INE

LAZAR RESEARCH LABS INC

LEDEX INC

LNC ENTEMPRITE

LDDAT ELECTRONICS INE

LOUIS ALLIS

LOYOLA CONTROLS INC

M D I SYSTEMS

MAGCAP ENGINEERING INC

MANCD

MANCD

MAXWFiL LABORATERIES INE

MACRDNETICS INC

MILALEE RESISTOR CORP

HOX EN ELECTRDAJCS

MURATA ERIE MOATH AMERICA INC

NEFF TNSTRUMENT CORP
LODE

ITEMS PURCHASED GY AULIS

ZIP APO

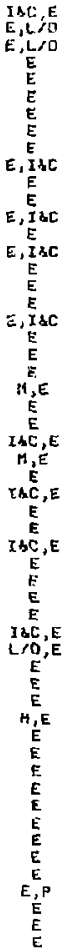

SWITCH, INTERUPTER SAFETY

95126

RECT IFIER

RECT IFIERS

UIRE WRAP

CORE TOROID

ALARM GLITCHES

CAPACrTORE

LIGHT FTXTURES

CENERAL HARDLARE

TRANSFORMER

PGUER CABLE, HIGH YOLTAGE

PONER CABL

CONNECTORS

CONNECTOR ME/COMPARATOR

CIRCUIT WREAKERS

ANODE CNAS

ANT SYSTEH

Q. THFR DNIZER

FEEDTHROUCH

guBstatians

INDUCTORS

AC/DE CONUERTERS \& SOCKETS

CURREHT MONITUR $6 /$ TRANSFORMERS

CONHEETOR HU/TERMIMALS, TABLE

P.LO. CONNECTOR

DIODES/THYRATRON FOR ABSOLUTE UOLTAGE

POMONA BOKES

KIMETIC BASES \& PINS

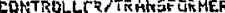

BIPILAR PUWER SUPPLY

TRAMSISTORS

HIEH VDLTAGE RELAYE

$k-L O C K$ MPLF

DIDDES

UNSTAQLE RESOHATOR JPOWER SUJPLY

PULSER, THYRATRON TYPE

ELECTREDE

SDLENOIDS

GRACKET DLODE \& HAEE FLATE/HELL JAR SUPPORT

CONNECTORS

GENERAL HAR DWARE

ECR CONTROLLER

MULT IPLEXERS

COILS, HFLF

POWEA SIPPPLIES

POWER EUPPLY

POWER GUPPLY

POUER RESTBTORE

HULT TPLEXERS W/ VOICE CHAMNEL/HODEMS

CAP ACITORG

ANGFORHER

AMPLIFIERS
POR OSCILLATOR

ENTRY PANELS/PQWER SUPPLIES

10701

95127

1247 ?

12470

94729

94600

94606

11550

94604

94607

92627

01301

94086

95131

3540

10509

95128

94002

94540

94534

91405

90510

De:58

01803

94096

92700

LBOA

91735

95000

75050

44062

9.303

83103

10707

43001

1274

01802

$4537 \%$

95119

94102

53001

92667

92665

05051

95051

07649

53204

95131

\%

9462

2 


\section{NEP'DORS - ELECTRICAL}

PLASTIC CAPACITORS INE

POTTER \& BAU

POWELL ELECTRONICS INC

PQWER MATE CLRP

POWER PRODUCTS

POWER SEMI CONDUCTORS

POWER SPECTDR

POLER SYSTEKS DISTR 1 EUTORS

PRECIBION GONNECTION DEYICE

PRINEETAN ELECTRONIC PRODUCTS INC PRIMCETON UNIUERGITY RESEARCH PROMEDIA CO

PULSE ENITINEERINE INC QUALITY TRANGFORMER \& ELECTRONICS $R$ D MATHIS CO

R G B ELECTROM IMDUSTRIAL

RCO COMPONENTS

RELIANCE ELECTRIC CO

REUTER-5TOKES IND

RICHEY ELECTRONICS INC

RKS INDSSTR IES INC

ROBIEOA ELECTRONICS INC

SANTA FARPARA RESEARCH CEMTER

SCHWEBER ELECTRONICS CORP

SCHWEBER ELECTRONIC
SEMTECH CORPORATI

GHEUEY ELECTROHICS INC

GIELCY ELECTRANYCS INC

SIEMENS-ALLIS INE

SORENSOH CO

SPELLMAN HIGH VOLTAGE ELEC CORP SPRACUE ELECTRIC TO

STANGENES INESTRIES INC

STAR TOOL O ENGINEERING INL

STEAH \& PLUMBIHG SERUIEE CORP

SUNAEX INE

SUPERTEX INC
SYSTRON DQHHER

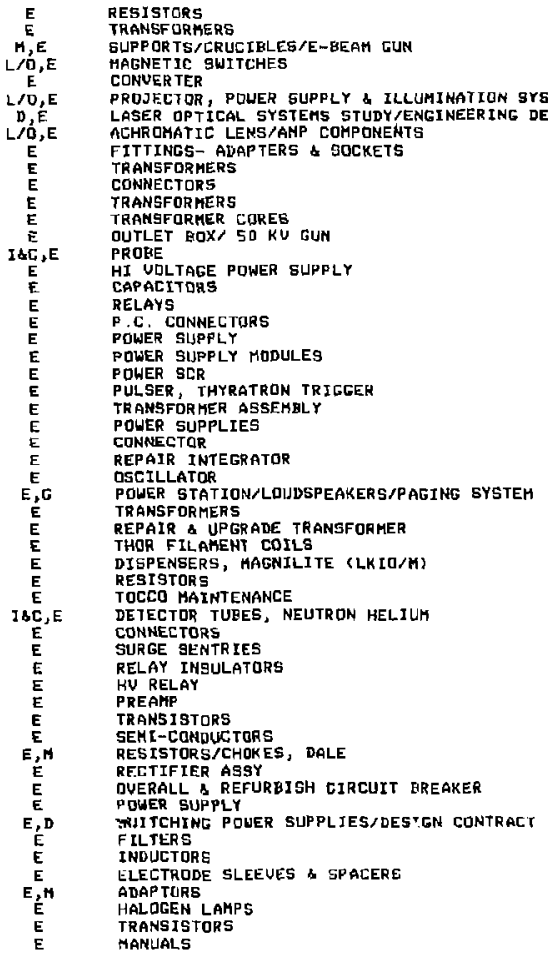

94621

11542

97321

04038

90621

91107

07006

94621

94404

94303

93086

94577

94566

95138

74 स2:

94006

95008

33060

06460

94577

95035

Q5121

1085A

0854a

94907

P5128

95035

90006

95112

95112

95110

4513

14128

95131

93401

95008

93117

9505

91320

94043

80020

74545

11803

94010

9430

94083

94103

02194

74520 
VENDORS - ELECTRICAL

CQMPANY NAME

T 1 RESEARCH PRODUCTS INC

TDK CURP OF AMERICA

TESTCO INC

TIME ELECTRONICE NDR/CAL

TOPAZ ELECTROHICS

TRANSCAT

TR I TRONICS INC

TRH INC (IRC BODNE DIV)

TRYCO UIDEO

TTE, INC

UHIUERSAL VOLTRONICS CORP

UTI-INSTRUHENT CO

VACUUM GENERAL

UDLTAGE MULTIPLIERS

WAUETEK-SCIEN

WESK ELECT EQUIP MFG INC

WILCOXOH RESEARCH INC

ZERO CORP
CODE

ITENS PURCHASED EY AULIS

$21+/ P 0$

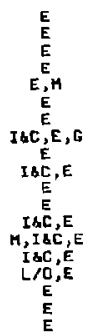

RESISTUR

CAP ACITOR

GOLENDIDS

RELAY LO EHF

CDNHECTORS \& CLAMPS

DECADE BOX, RESISTANCE, CAPACITANCE \& INDUCTANCE

MONITORE $/$ IIDEO PLAYER

RESISTORS

UIDEO BPLITTERS

FILTERS, ACT IUE L

POWER SUPPLIES/BLOWER

ANALYZER

CONTROL HODULES/CONTROLLERS/PDWER SUPPLY a CABLES

DIODE

FILTER, BANDPAES BRICKWALL

SCR TRIGGER UNIT

IMPEDANCE HEADS \& UIBRATIDN GENERATORS

HOXES, UNTR IMMED

95035

14606

28607

4802

9006

10549

94806

92111

93291

07647

92649

20814

94303 
AERDJET ELEC

APPLIED LASER ELECTRONICS AUCO EUERETT RESEARCH LAB INC BECHTEL NATIONAL INC BUFFALO FORGE CO

COOPER LASERSONICS INE CUSTOM CUMPUTING SERUICES DECISION PLANN INE CORE DIETER ICH-POST CDMPANY DUGOUTH INDUSTRIES ELECTRO OPTICNL SYSTEMS ELECTRD-OPTICAL ENERGY SYSTEH INE FAUSKE ASSOC. GENERAL ELECTR IC CWESTERN

INTERMATIONS

ISH

KAISER ENGINEERING

LOS ALAHOS TECH AESOC INC MATER IALS RESEAREH CORP MATHEMATILAL SLTENCES NOR THUEST METRQ SUPPLY

$\checkmark \quad$ OPTICAL RESEARCH ASSUG PIPELINE SYSTEMS INCORPORATED SAN FERNANDO LAES SCIENCE APPLICATIONS INC SELAES INL SNAMINON OPTICAL SYSTEMS INC SPELLAAN HICH UDLTAGE ELEC CORF STONE \& WEBSTER ENGINEERING CORP UNIDN CARBIDE (DEGRODT DIU) UENTURE ANALYTICAL, ASSOC INC

OPT DEGIGN SUPPORT

DESICN COHTRACT \& POWER SUPPLY

LASER STUDY

EHGI NEER INE DESIGN S SUPPORT

FAN DESIGN \& FAER ICATE

DES CONTRACT PPTLEF SUPPLY SUITCH \& COUAPLAS

CONSULTINE

IMPACT ANALYSTS STUDY

DRAFTING FOR MARS/DRAFTING LITES

STUDY/TECH ANALY

ENG INEERING DESIGN

ELECTRO-OPTICAL ENCINEER INC

SAFETY ANALYEIS

ENGINEERING DESTGN GERUTCES

ENG INEER ING SERUI TES

GLAzEs Jatats

CIRCUIT GOARD DESIGN

ENGINEER ING DESIGN SERUICES

PROCESS CONTROL SYSTEM STUDY

COPPER RODS/ANALYSIS OF U SAMPLES

STUDY-LASER INDUSTRY ENUIRONHENT. HI PHR

AFTING FUR MARS $/$ DEVELOPER

LASER OPTICAL TYSTEHS STUDY/ENCINEERING DESIGM SERUICES (PSA PSI)

COATINE DEUELOPNENT/CARBURIZE CRUCJRLE

COATING DEVELOPNENT

EUALUATIDN/REPAIR P DWER SUPPLY

PURONAL SERUICLS AGREEMENT

DESIGH CONTEAC

ENGINEER XME

PLASMA HEATING STUDY

LINE OF SIGHT, YLDE 4 H

CONGULTING SUṔPORT FOH SOFTIJARE

94040

94623

67544

9505046

90904

02

91107

32931

11803

95616

24020 
3 M BUSINESS PRODUCTS A CONTAIHER gALES ACE GLASS INC

ADOLF GRASSER INC.

ALLADIN

ALPATH ENTERPR ISES

ALPYA PHOTO PRODUCTS INE

ALPHA SCIENTIFIC IMC

ALUTH A CO INT

AMER ICAN HDSPITAL SIIPPLY CORP

AMER ICAH WHOLESALE TARPAUL IN

AHERICAS

AMPEX CORP

ARK DISTR I BUT YOH CO INC

ARHSTRONG STATIOHERS

ARADU STAB IHI

AUTOCLAUE ENGINEEAS INC

AUIU CORPORATION

A $C$ TOUCK

DAL SCREHS ACTUATORE CO INE

BASIC SYSTEMS CORP

BEL AIR CAHERA H H-FI

GESS TESTLAB

BICKLEY FURNANCE INC

BIGEE CRAHE

BIO RAD LAPJAATCRIES

BRENTON GAFETY IHC

GRILL ELLCTRONICS

BROWN GUUER I ELECTRIC INC

C i TALOR CORP

CAL-TECH METAL FINISHERS

CAL TFORNIA ART SUPPLY INC

CAL IMET PHOTOGRAPHIC IWC

CAH DESIGNE INC

CAMP PELL DESIGN GRDUP

CLARK PATNTING CD

CLARK PAINTING CO

COLL IMS INTE

CONTAINEF STORACE INC

CDNTAINEP STORAEE INC

CREATIUE OFFICE PRODUCTS INC

CREATIQE OFFICE PRODUC

DAUID SEHHIDT

DENEUI CAMERA

DICTAPHOHE

DIETERTCH-POST COMPANY

DI HENSIOHAL CONTROL CORP

DON D FLEHING CO INC

DRAFTETTE CORP

EAKINS ASSOCIATES INC

EAST BAY FIXTURE CO

INDUETRIal SALES INC

ELMHURST ANODIZING MFG CD
DFFICE SUPPLIES

TRANGP ORTAINER

CAMERA REPAIRS

FLAEKS

CAKERAS

PLAZA HODEL

SCREEN

RESET ISD. IND ASSY
DRAFT IHE EDUIPMENT

ANALYIICAL EALANCE

TARPS, VINYL

WELD KIT

TAPE, 1" ON PRECIBION REELS

BEAKERS

CABINET

REPAIR KITS FOR PUMP

GAUNT/TAPE CONTROLLER/MAINTENCE OF AUIU SYSTEH

FILTER A5SY.

SHAFTE \& NUTS/ENGINEER TO SERUTCE MARS

RIBBON CARTRIDEE

NIKON CAMERA

IMPREGNATE CASTING

FURNACE REPAIR

EQUIP MENT RENTAL, LABOR, SERUICE

ION EXCHANGE REEING

DRY BOX GLOVES

GRUSHES, WELLER

STANDARD5 - METAL \& ALLOY, HALOGEN \& BENLE ALGEE \& 94545

ALLOY, HALOGEN \& BENLE ALBEE \& 94305

ZLACK OXIDE COAT

DRAFP

F ILES/FURNITURE

FAIN BOOTHS/REPLACE GLASS

LEUELING FEET TOOLING

PIPE, ELEANINL ' COATING

TRITON BOX \& MODEL

WIRDOU BLINDS

TRANSP DRTATDR

SWTUEL CASTERS

TYPEDISESDISC HOLDERS

DRYBDX GLUUES

DRYBDX GLUUES

CAMERAS A ACCESSOR

DRAFT L LITES

CALTPCRS GRIUGEPIIRT KNEE

CLOTHES LOCKERS

DRAFTETTE

TRP DRIUES REPAIR DISK DFIUES

DISPLAY CABINET

GLACK OXIDE ON PART
55133

94119

94553

94577

94553

94612

94544

94006

90015

94763

4553

11563

94105

94903

95112

90024

950's!

19114

94577

94804

94080

94610

94610

94553

\%

94518

74546

84596

94807

94400

460

940

945 ht

$945 \pi 6$

94107

544

945

92126

94041

94600

92715 

PALIFIE SAW WORKS INC

PANEL CDNCEPI IME

PAT PATTESOH ASBOC

PHILLIPS MFG CO

PHLTO SHOP

PLASTICRAFT UNLIHITED

POLYHETR ICS INC

PREHIER METAL PPDDUETS CD

\section{PRINT-IT}

\section{PRCMEDIA CO}

QUANTA-RAY

RAMTEK CORP

RCA SERUICE CO

RECOGNITION CONCEPTS INC

REDWODD STATIOHERS

R IGAKU/USA INC

ROBERTS, JG

$S$ R I INTERMATIONAL

SAUTER DIU

SEARS ROEEUCK ACO

SEHIFAE INC

SENCORE

SHELTER SHED WAEHTHGTO INC

SHOKEETER OF NOHTHERH CALIFORNIA

$\checkmark$ SPECTRA OPTICS

SPEK INDUSTRIES INC

SS SPECIALI: IES CO

STANCII CORP

STOHLER ISOTOPE CHEHICAL INE

GIRICK LEASE INC

GTRICK LEASE INC

SUNNYUALE STATIONARY CO IRG

SUNNYVALE STATIONA

TAB PRODLCTS CO

THOMAS A SHDRT CO

TRM WALSH \& ASBOC

TRI TPGAILS INC

ULTRAKET

ULTRAKET

USA HODELS

VARI AN ASSDC

UIC HUEBARD SPEED \& HARINE CORP

UIDEOHEDIASSED INE

UWR SCIENTIFIC INC

W P KEITH INC

HATER WORKS MFE

WAVETEK

WESCD

MESPERLIKE

WEST COAST CONTRACTORE INC

WESTERN CONTRACT FURNISHER WESTERN DYMEX

WESTERN TELEMATIC INC

WEST INCHOUSE ELECTRIC CORP

WH. A GORE CO

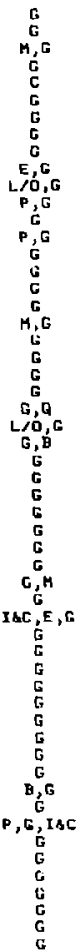

REPAIR/GHARPEN SAH BLADE

PAR VAC PUMPS/REPAIR PUMP

SAR VAC PUHPS/REPAIR

CLËANER, UL

CANERA CALE

LEAGE OF HIXED BED DEIONIZER

CABINET DODR

PRINTINIT \& PAPER

PUWER STATIOH/LOUDSPEAKERS/PAGIHC SYSTEM

LASER/CRYSTALS/ETALONS/REPAIR LASER

PR INTER/NAINTANENCE ON CLLOR TERHINAL

TU CART

PIP CARD/PROCESSOR - REPAIR

EPSON RI IBONS

REPAIRS

CURUES ADJ

TUNE PHONES

BALAMCF.

TRIPODS/ICE MAKER/REFR ICERATOR/OUEN

TABLE, LAMINAR FLDW

Z-METER/GRIDGE ANALYZER \& ACCEGEOR IES

CONTAINERS, DRY, REFURBISHED

PREUENTIUE MALNT SERUICE/GMDKEETER H.C.

LASER GOECLES

LAE GLASSUARE, URAHIUH EY NITRI

RECORDTNG SYS

CHLLOROFORM AHPULES

LEASE GF UANS

STOQLS

FILE. gYSTEMS

SHELUING

RUBEER BQOTS/ENCLOSUAE SPDNGL GASKET

MUDULAM OFF ICES/LOCKS

DLAYE

FOLDERS

MAINTENANCE \& SERUTCE ON A VARIAN

BLAMKET, EXPLOSIUE

CAMERA S LENS

NYLON GLOUES/HALANCE/HICROGCUPE LENS

FURANCE MODIFY

STEFL PIPE/STDOL

MANUALS

SOFTWARE/SWITLHEOARD/VOLTHETER

CABINET

LABER ACTIUGTION WORK

TABLE BASES/TAELE IINSTALLAT1OH

REPAIR DISK DRIVE

SWI TCH, G-PORT SMART

SUI TCHEAOAD

SHELYINE STEEL
94615

94711

0

60626

9466

94103

7513

94550

94107

94043

95050

94621

89450

94025

01923

94604

94002

94566

94550

95023

57107

94107

94560

91342

9551

90038

02454

02154

95110

94096

94103

94662

95035

91505

9009 i

91331

19023

77478

$940 \mathrm{~B} 6$

94541

74086

$9411 \%$

90660

95901

94086

75625

95050

94533

95126

05019

9270

44623

94b07 

A. BIEDERMAN IME

AAC INC

ACT IOW INSTRUMENTS CO INE

ACTIUE CONTROLS IMSTRUHENTATION ADUANCED THTEGRATED TECHMOLOCY

ADUANCED TECHNDLOGY CO
AMER ICAN AER

AHERICAN MAGNETICS INC

AMERICAN SCIENTIFIC PRODUCTS

AMERTLOM ELECTRONICS CDRP

ANACON INC

ANALOG DEUICES INC

ANTHEY ELECTRQHICS IES

APEX MICROTECHAOLOGY CORP

ARROW WELDING

ASSOCIATED PRUCESS CONTROLS

ASSOCIATED

AUDIO VIGUAL

ALDTOTROHICS Cr $\mathrm{OP}$

AETEC ENGINEER: G INC

IBUT.RS INC

BAY SEAL CO

BELL INDUSTRIES

GELL. INDUSTR IES

BERKELEY NUEL

GQMAR/ALI INC

BOSS TDOL MFC INC

EROOKS INSTRUMENTS

BURKE CO

INSTRUMENTS -

CALIFORNIA UIDEO SALEB INC

CALOR IMETRIIS INC

CANEERRA IHDUSTRIES INC.

CARGOLL TDUCH TECHHLLCY

CENTRONIC INC

CLAUDE S GOADON LD

CLEAR-COH INC

CMS INTERNATIONAL CORP LTD

COHERENT INC

COHU INC

COLORADD UIDEO INC

COLUME?A LOHPONENTS CD

COML INEAR CORP

CONCEPT ENGINEERING

CONSOLIDATED ELECT WIRE \& CABLE

CONSDLIDATED PARYS INC

CONTROL TECHAICS CDRP

COULTER ELECTRONICS INC

DAK I NDUSTRIES

DATEL INTERSIL

DELTA F CDAP

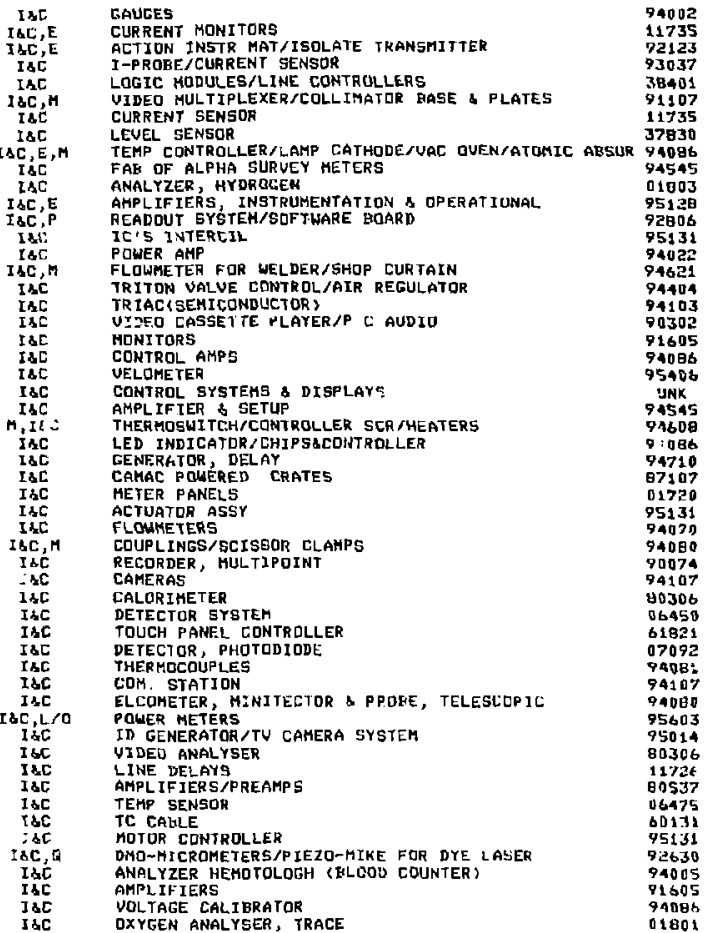

4002

1107

7830

4096

1003

128

5131

4022

4404

4103

1605

(1)

INK

454

ig6h

(1710

1720

5131

94000

0074

40306

6450

7093

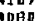

5603

0306

0537

6475

5131

405

1205

01801 
DELTA ULTRA SENSE INC DENTON VACUUM IML

DIMAC

DINUCCIS MACHINE SHOP

DRANETZ ENGINEER IKG LABORATORIES DRF ALEDCIATES IND

DUPONT ANALYSIS

DWYER INSTRU

E \& I COOP

EARHARK INC

EATOH CORP-ELECTRDNIC INSTRUMENT DI EBERLINE INSTRKENTS

ECTRON CORP

FGAG INC.

EI DU PONT DE NEMUURS CO INC

EUL INSTRUMENTS INC

EL INSTRUMENTS INC CO

ELECTRONIC NAYIGATION INDUSTRIES

ELECTRONIC

EMERGENCY PRODUCTS CORP

EMILE HAEFLY CIE AG

EHDEUCO CJRP

ENI J.NC

$\checkmark \quad$ EUANS ELECTRONIC

FABTECH ELECTRDNICS

SALES INC FERNSEH IMC.

FLW INC

FOX HARDWARE INC

FOXEORO CD

GALILEO ELECTR-OPTICS CDRP

CEH TE

GENERAL ELECTRIC SUPPLY CO

GENERAL ELECTPONIC SYSTEMS INC

GENERAL SEHICONDUCTOR IHD INC

GESI AUUIJ VIDEAO SYSTEMS

GLOBAL EQUIPAENT CO

GOULD INE (BIOHATION DIU)

GOULD INC (MODICDN DIV)

GOULD INE(INSTRUHENT DIV)

GOULD INC

GOW-HAC IHSTRUMENT TO

GRANUI:LEE-PHILLIPS COMPANY

GROUP THREE ELECTRONICS

GULTON INDUSTREES INI

HALL-HARK ELECTRONICS C

HAMAKATSU COAP

HARREL INCORP JRATED

HARRINGTON INDUSTRIAL PLASTICS

HELICAL PRODUCTS CO IMC

HIGH UDL TACE ENGINEER INE CORP SANAC

AERICA LTO

HOTROYIC5 INC

HUGHES AIRCRAFT (INDUSTR YAL PRODUCTS

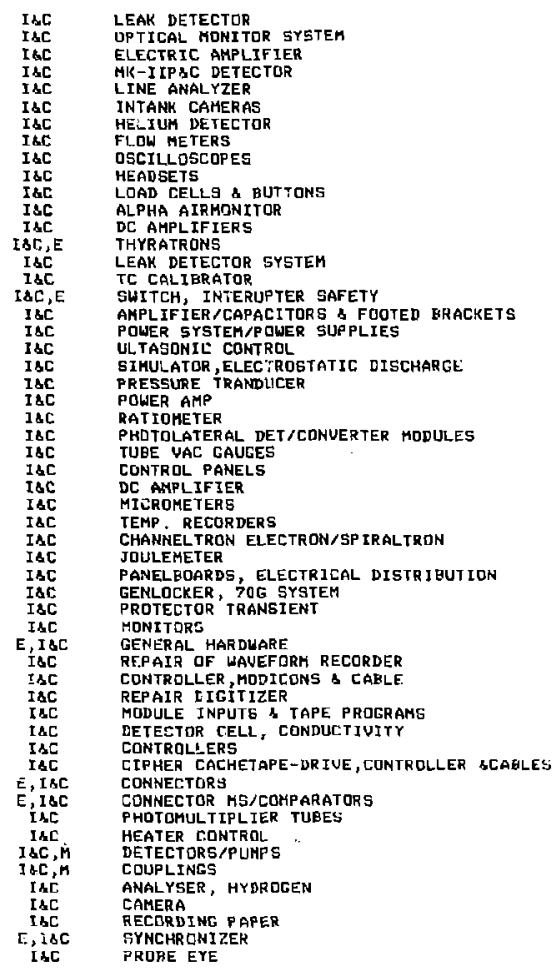

94583

08003

95008

94518

08818

92111

19890

92801

92715

94612

483 ?

87501

9454

90074

95050

95126

95126

94040

07054

ร4I

SUITZER

82675

94025

94705

94513
84577

845

94131

94544

4457

01510

9999

94608

94702

65ว41

94702

11550

95050

95050

14010

08807

54906

94089

92427

84096

75120

95128

94710

94710

73456
01807

0180

90746

9512

94705 
HUNTER 1ECHNOLOGY CORP MURST MANUFACTUR IHL CORP HY-CAL ENGINEER INE

IET LAES INC

TMDUSTRIAL DATA TERHINALS

INT SCIENTIFIC

INTEC

INTERFACE STANDARDS

INTERNATZONAL BCIENTIF IC TNST INC ION PHYSICS CORP

IRTRONICS

ITT ELECTRON TUEE DIU

JENBEN TQOLS INC

JEOL USA INC

JOERTER ENTERPRISES INC

JOHN FLUKE MFG CO INC

JOHNS CRYOGENICS

KAMAN INSTAUHENTATION CORP

KAYE INSTRUHENT INE

KËITHLEY INSTRUHENTS IHC

KENSINGTON LABORATORIES INC

KINETIC EYSTEMS INC KULITE SEHICONDUCTOR PRODUCTE INC LALSPHERE

LAKE SHORE CRYUTRONICE

LANDIS GYR INC:

LASER PRECISION LORP

LEGROY

LECROY RESEARCH SYSTEMS CORP

LIUERHORE ENIEINEER ING INC

LUDLUH MEASUREMENTS INC

LUXTRON

MARCON IMSTQUMEKTS IHE

MATHESON

HAXIM ELECTROHIC 5 ALES

MEASUR ITE

MEDICAL ELECTRONIC DESLGN INST

\section{MERET INE}

HETERMASTER INC

MICRAMINT INC

MOLECTRON COR

HORGAN ELECTRONIES INC

\section{MADY BYSTEMS IME}

MAHH BROTHERS SPR ING CO

OHTO SEHITRONICS INC

PALE-SETTER PRODUETS CO INC

PALE-SETTER PRODUCTS CD INC

PALIFIC ELECTRICAL SUP

PACTFTC TNSTRUHENTS

PCA PIEZTRONICS INC

PERKINS-ELHER CORPOAATION

ISC P.C. TIMINE CARD

95050

CUNTROLLER, STEP HOTOR 47670

PT TEMP SENSOR $\quad 71731$

TEST EQUTPMENT

TESTER/TOUCH PANE:

MICROSCOPE, ELECTRON SCANNING UNK

UIDED SPLITTERS $\quad 91720$

REPAIR CAHERA 94649

CONTRLLLER/CAHAC INTERFACE/SCANAIHG A/O 94539

TICROSCOPE, ELECTRON SCANNING

CUH RENT HONITORG TRANSFOR KERS

PYRQAETER, TWO COLOR 0690 ?

DIODES/THYRATROH FOR ABSOLUTE VOLTAGE 1804 ?

THERMUMETER/DRILL SETS

MICROSCOPE, ELECTRON SCANMLNG 01980

CONTROLLERS

CONTROLLER/TRANSFORHER

LN COHTROLS $P / C$

HEASUREHENT GYBTEH, DISPLACEMENT

CONTROL SYSTEMS \& DISPLAYS

HICROAETER A AS9/THERMOCOUPLE SENSOR

HICROSCOPE POSITIOHING SYS 94804

CAMAC MUX/UENUS COHTRQLLER \& ADAPTER 94566

DIGITIZERG

TRANSDLCERS, PKESSURE - 94595

SPHERES/DETECTORS

43001

10523

RATIOKETER/POWEP METER

DATA LDIEGERS, FUNETION GENERATORS \& MEMORY

DATA LOCGERS, 32 CHANHEL

CONTROL AMP

RATEKETER, DUAL ALPHA

THERMDMFTER WITH PRDPES

POW A SCOPE

STAINLEYS RECULATOR \& AS/GALEES

CURRENT METERS GUN BELL

CURRENT METERS, GUN BELL 95051

THERMOCDUPLES/THERHOHETERS

REPAIR RADIO INTERCOH/HEADSETS . 94612

PHDTODEECTOKS 91704

UQL TMETERS \& COHTROLLEAS

REHDTE CONTROL KITS 11526

LASER TMETER, RADIATION

RELEIUER \& TRANSHITTER

VCF \& CATERA 94600

DOUR GENSOR CILIPS

TRANSDUCERS

MICROLAUE CAUITIES LAMPG, ELECTRODLESS 208SS UMOS DRIVER CHIPS/TRANS IST IRS AMAETER POLEEA SUPPLY GENERAL ELECTRILAL HARDWARE 07492

$\begin{array}{ll}\text { ACCELEROMETEI } & 14043 \\ \text { ION GLN/ELECTRON GUN } & 95119\end{array}$ 
JENDORS - INSTRUMENTATION \& CONTROLS

COMPANY NAME

PHALD CORPORATION

PHDTAHP

PHYSICS INTERNATIONAL CO

POCNTING PRO

POLYTEC DPTRONICS INC

PRECISION DIGITAL

PRINTED CIRCUIT BUILDERS INC

PYRDHETER INSTRUMENT CO INC

$R$ U HEATHERFORD CD

RADIATION MONITOR IHE

RADIO SHACI

RASTER TECHNOLOGIES

RATEL ELECTRONLCS

RATIO CONTROLS CORP

RCH INDUSTRIES

REUTER-STOKES INC

ROAERT DOSCH CORP (UIDEO EQUIPMENT D

ROCHESTER INSTRUMENT SYSTEKS INC

ROWE INDUSTR TES

SCIENTECH INC

SENSYM

SERUD-TEK OF CALIFORNIA INC

SIECDR CORP QRATION

SIEGER GASAL

SLOAN TECHNDLOGY CORPORATION

SULAR ENERGY DISTRIDUTORS INC

SPEEDOMETER SERUICE

STANDARD ERGINEER IMG CORP

STAKDARD METER LAB IHE

SYCON

TECAL SCIENTIFIC INC

TEKTRDNICS INE

TELEDYNE (HASTINGS-RAYDIST

TELETRDN IND

TELTONE CDRP

TENAELEC INC

TEXNATE INC

II HE-TROL

TOCCO HEST

TRACOR NORTHERN INC

TRANSIAC COR

TRI TRONICS INC

TRDMPETER ELECTRONICS INC

TRYCO VIDEO

TYLAN CORPORATION

UNITED DETECTOR TECHNOLOEY

UTI-IASTRUMENT CO

UACUUM GENERAL

VAL IH

UALLEY ELECT

UANZET I SYSTEYS INC

VARIAH (JND PROD OPER SERU)

UIDED SHACK

UDL TAFE HULTIPLIERS

WALKER SCIENTIFIC INC

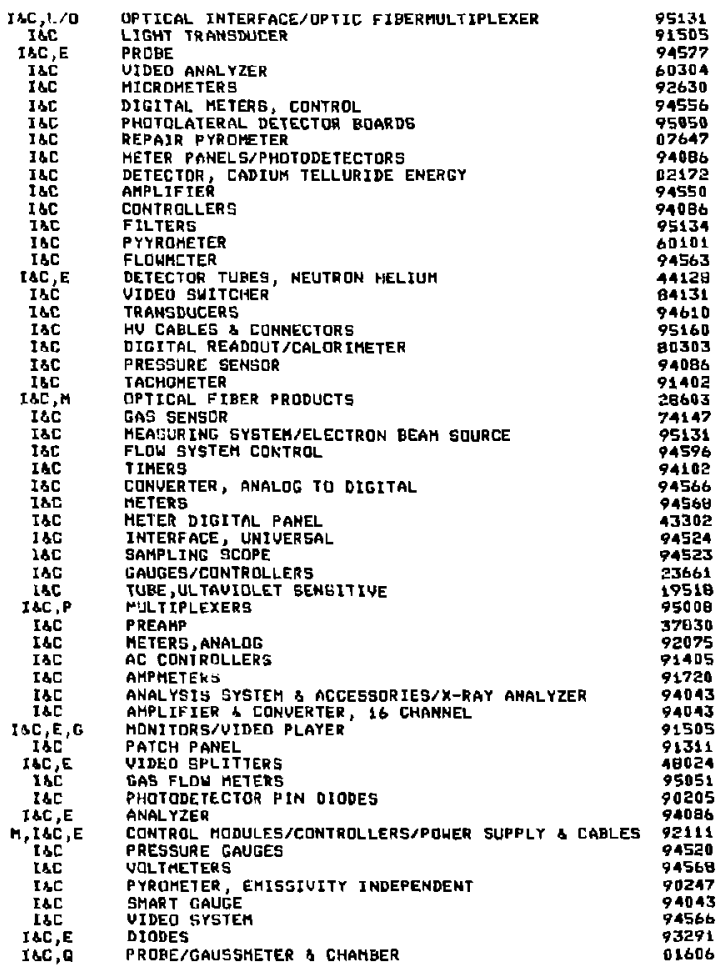


VENDORS - INSTRUHENTATION \& CONTROLS

COMPANY NaME

WARREN COMMUNICATIUNS

WAVETEK INDIANA

WESCD

UEGTERN MICAOTECHKOLOGY INC

HESTERN TOOL \& EUPPLY CO

WESTON INSTRURENTS INC

WEGTRCNIX LP

WYKO OPTICAL

Y.C.A

YELLOW SPRINGS IASTRIHENT CO INC

ZI-TECH INSTRUMENT CORP
CODE

ITEHS PURCHASED BY AULIS

AIRFLOU SENSDRE

UIDEO HARDCOPY

$P, I \rightarrow C$

$P, G$, LAC

Íc

IsC

IsC

IsC

ISTC

I\&C

SOF'TARE SULTCH 8OAR O JUOLTHETER

C. ANALOG GHIPS

INDICATORS

IETER PAMEL JUOL THETERS

VOLTAGE PHASE CONIRDL

LASER TESTER

GHART RECORDER

TEMPERATURE MEASUREMENT CARDS \& PROBES

SUI TCHES

ZIP/PO

07039

84043

95625

95014

94605

94063

92621

85712

94523

45397

94025 

DAYTON-FRRES

DEL REY SYSTEHE INC

DIGIT MICROSYSTEM

DIGI TAL EQUIPHENT COHP

DISCOUM

DITECHS

DIT

DJC

DUWAYME INDU

DAKINS ASSOCIATES JHL

FAXININC

GLENA A. BAREER ASSOL INC

COID SYSTEMS

HERCLES COHPUTER TCCHNOLOUY

HEWITT PACKARD COMPUTER SUPPLIES

HOME \& RUSGINESS

IDM PERIPHERAL

IFH INC

IHAGINT TECHNOLOGY JNC

INFOMAX INC

SYSTEMS

INMA

INNOUATIVE SDLUTIDNS IHC

INTEGRATED ELECTRONICS-JACQ

KNYERACTIUE RALIATIUN INC

INTERLAN INC

INTEX MICRO SYSTEHS CORP

ITH

KEHHEDY WUSIMESS HACHINES

XINET IC SYSTEHS INL

KROY INDUST

M/A-EOH ALANTSIUS DATA INC

MDE SYGTEMS IHC

MEDIA DISTRIBUTINC

HICRAJUST

MICRO LOEIC CORP

MICRU TECENDL OCY INC

HICROAGE COMPUTEA STORE

MICROSOFT

HICROSYSTEMS ENGIHEERING CORP

MICROWARE INC

MIDLEST SYSTEMS INC

MISCD INCORP

MOORE COAPITER SUPPLIEE CATALOG

MOXUN ELECTRONICS

MPC PERIPHERALS CORP

MULTI-1ECH SYSTEMS INC

NATIONAL INSTRLMENTS

NATIONAL SEHICONDUCTOR CORP

NCA CQRP

NRCOLET SCIENTIFIL CORE

OKI SEMICONDUCTORS INC

OHNEX CORPORAI I IN

P C SOLUTT

PDA ENGINEERING

PFINTER

SERUICE. CUNTACT-COAHPUITRES A INITKLITCS

$9454 b$

0045

03001

40030

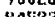

9.73\%

24563

945

94523

941)41

94510

71403

Y4111

भavil

94lut

$7454 \mathrm{~L}$

94040

01802

$945 \%$

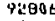

T40us

95815

95120

17647

94043

48004

94598

94096

44566

94404

94404

Y2645

9506e

$9140 \%$

07602

94041

94523

7uU 04

S0195

(1)2601

5533 ?

orrac

orrac

b.

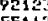

5

7.

ror



प134

isos

74303

94549 
PER I TEK CORP

PER SONAL CAD GYETEME INC

PHOTO \& SOUND CO

PLUTA AHD ASSOCIATES

POWER UP

PRECISION ECHO

PRO-LOE CORP

PRO-LOG CORP

PSDI

PSDI

RACAL-VADIC INC

RAHTEK CORP

RANTEK CUR

HECOCNITION CONCEPTS INC

RESEARCH INC

SIERRA COHPONENTS INC

SIERRA CDMPUTER SUPPLIES

H? INC

SINCLAIR OPTICS

SKY COHPUTERS INC

SUF SEARCH

SUF THERD SYSTEHS

W SORCIH CDRPQRATION

STANFORD RESEARCH SYSTEMS INC

STEVEN ENGI MEER ING

STONEWARE IN

STRUCTURAL MEASUREMENT SYSTEMS

SURLFORM

SYSTEMS INDUSTRIES INC

$T$ L MORRIS S ASEOC

TAU CORPQRATION

TECHAICAL FURNITURE SYSTEMS

TELESOFT

TELEWIRE KBL

IEXAS INSTRUMENTS INC

THRESHULD SDF TWARE. INC

"OCCD ALAEATHA INL

1] S DESIGN CORP

VERSATEC

W A BROWN CO

WANG LABORATOR IES INC

WAUE IEK INDIANA

LESC

WESPERCDFP

WEST LDAST COMPUIER EXCHANLI W.

WEST - MICROSYSTEMS

WYANT MEASUPEMLHSE IHC

ZACK ELECIRONLLS
DISPLAY, MTHITOR A SUFTWARE

SOT TWARE

CONTRCJLLER, CAMAC

SOF TWARF

RECORDER W/ DISLASSETTE A ASS

PAINTER FUFFER

PROH PROGRAMMER

P. C. S A ACCE SSURIES

SOF TWARE

QUME DR IJE \& CIRCUIT LOARD

MODEMS

PRINTE 'MAINTANENLE OH COLOR TERMINAL

PRINTEK

PIF CARD/PROCESSER REPAIR

MILRICOH OPERATUR

DISC CONTROLLER

POWEH SUPPLY

CHASSIS HITH QRUAD

SOFTWARE LICENSE

SOF TWARE LICENSE

GOF TUARE SERUICE.

SOF TLARE

SOF TWARE

SUF TWARE DEUELITPMENT

EOXIIAR AUERAGER

SDF TWARE

SOF TWARE

SOF T WARE MODELS

COMPUTER

DEE SERVILE/COHPLTEK SYS

REPAIR FLUPFY DISK DRIVE

SOF TWARE

CDHPUTER COHEOLL

SUFTLARE UPUATFS

MODEMS

MULIIPLEXERS

PRINTER

SUT TWARE

QEPAIR DISC, INCHESSTER HAIXD DISK

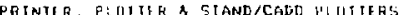

CTMPUTER HAR DWARE

HARDWAYE A SOF TWARL

UIDEO HARDCOPY

SOFTWARE TSWITCHETARL: CNU TMI TI

IAPE CONTRULLER
DISH SYSTEM/LOGTC HUEULES

UIVIE

A I U UAR E

IYIEWEITEH, SUI I WIREE
94619

94105

94566

94019

95054

91311

45303

94111

94545

94086

95050
05131

25131

09450

75050

7402

95008

9500

24534

95020

33908

$0610 \mathrm{~B}$

$95+11$

92121

94306

94380

94901

95134

750 คे

95035

94550

95030

44087

92121

$7456 \pi$

$9500 \mathrm{E}$

O4111

QSH1S

91720

207116

44564

7 d.te日

890.1

Y5.

Y)

05670

Q',

(11)

115?

प4hl: 


\section{A. JAEGERS}

AERO-SPACE WELDINC CO AEROTECH INC

AIRTRDN

ALL IED COFPOAATION

ALPHA GROLP INC

ANDOUER CDRPORAT ION

AMTENIEUX COHP OF AMERICA INC

APPLIED OPTICS INC

ARTEL COAMUNUNICATIONS CORP

ASTRD MET

AVTECH ELECTROSYS1EHS LTD

AVTECH S COHG THC

BEARIHE ENGINEERINL CO

BEARING ENC

GERYELEY GLASS LAE

C N E EMCTMEERINC

C N C ENCINEERIN

CARAL INC

CARAL INE

CAST ALUMYUUL INSTRUMENTS

CAST ALUMXNUH a BRASS CO

CHAMP CO

CLEUELAND CRYSTALS INC

COHERENT INC

SCIENTIFIC CORP

CONTINENTAL OP TICS COR

CORTIRG GLASS

CORNING GLASS MACHINE

COVENTRY TODL MACHINE

CRYSTAL SYSTEMS INC

CRYSTAL TECHNOLOGY INC

CURRENT PRODUC

DESIGN OPTICS

EALING CORP

EDKUND SCIENTIFIC CO

EIRCAR PROD

ELECTRDN TECHNOLOGH INC

ELECTRONIC DEUICES INC

EMCEE ENTERPRITES

ESCO PNŨVULIS

EXCITON CHEHICAL LO INC

EXTRANUCLEAR LAEORATQRIES INC

F1 BHER GROWNELL

FLUOROCARBDW

FORDHAR RADIO INC

GENERAL FIGER OPTICS

GENERAL DPYICB INC

HARSHAL CHEMICAL CO

HERAEUS-AKERSIL

HOLLAND TNDUSTRIES

ILE TECHNOL OSY

INF ICOH LEYBOLD-HERAEUS

INFRARED INDUSTR IES INC

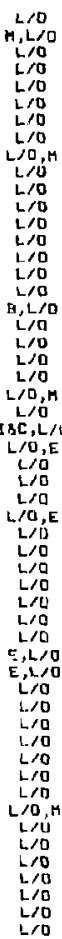

ACHRQMAT LENS

ALAD CLAMPS \& BASE/4CM OSCILLATOR

MiRROR MOUNTS

GINEAR AHF/DYE WINDOW ASSY

METGLA'S

AEA BSCILLATQR

IRANS WTAR

CU FIEER OPTICS

POROUS TUHGSTEN TUBES

LENG

GRATING LASER

TELESTOPE PKG

OPT IC FIEER CAELE

QUARTZ TURE CC/A LASER

QUSHINGS FASTENERS/LASER TUEES

LASER MIRRORG

3 " TURNINC MIRRDR

IMUESTOSCOPE/ZEISS GVG

CYL CASTING

TELESCOPE ASSY COLLLETOR IANK

KDP SAMPLES

\section{PUEO METERS}

ION SOUREE/PWR SUPPLY, MILLATRON S PARTS

CUL. 3* UINDOW'SHEAR PLIEEAM SPLITTFR

TELESLUPE

CUL WINDOW HLANKS

BPTICS PKG/LINEAR AMP

SAPPHIRE

CRYSTAL/OPTIC MUDULATOR

3" ACHROMATIC LEN

MLRRORS

OPTICAL FILTLRS

LENS TISSUE

ALUMINA CYLHDRG

RECTIFIER

RECTIFIENS

LASER TUAES

OUARTZ OPTICS/LONCENTRIE REDUCERS

LASER DYE

IONIZER CROSSEE,AM

AHBER LENS

QUARTZ TURES \& TAEE

MAGNIFIER, LAMP

OPTICAL FIEERS

SUBSTRATE UPTICS

NAF CRYSTAL LASER WTNDOUS

GUPERSILS, ULTRASIL B CUTTING CHARGE

MIRROR HOUNT!

FLASHLAMPS

REPAIR AUX SENEDR

IR TILTERS

0722740

07054
94577

01843

03051

94523
06497

01602

01602
45215

11101

11101

14625

91103

04538

94538

94550

07112

94706

94610

$9457 \%$

95008

41117

22314

$11 \% 88$

15238

14831

95035

01970

94303

93663

940166

01\%60

08002

10921

07032

10701

945\%7

94608

45431

15238

95050

44096

11280

02006

93021

44138

08872

90680

$\$ 4006$

94086

32891 
INAOUATIVE SOLUTIONS INC INRAD

INTEROPTICS

INTEACTION CORP

IRCON INC

ITEK CDRPURATION

JANOS TEChMOLOGY INE

JODON INCURP ORATED

JOHATHAH MFE CORP

JUC

KAPTROH INE

KARL. LAYH

KENLAR

KEUFFEL \& ESSER C

KLINGER SCIENTIFIC CORP

LAGUNA LABURATORIES INC

LAKBA PHYSIK

LASER INC

LAEER OPTICS INC

LASER FOUER OPTICS

LASER TECHNOLOGY INC

LECO CORP

LUHDNICS RESEARCH LTD

MATER IAL PHYSICS

MATER IALS BY METRON INE

MATH ASSOCIATES INC

HAX I.EUY \& CO

MOTION INDUSTRIES IND

FOTT METALLURGICAL CORP

NEUPORT CORP

HSG PRECISIOH CELLS

NUHERIC MACHINE

OPT IC FAB CORP

DPTICAL COATINE LAB INC

OPTICAL INSTRUHENTS

OPTICO GLAGS FAER ICATION INC

DP TICS FOR RESEARCH

OPTICS PLUS IHC

OFTO-ELECTROHICS LTD

OR IEL CORP

PACIFIC SAFETY EQULHENT CO

PANAMETRTC:

PARAMDUNT INDUSTRIES INC

PERKINS-ELMEK CORPARATION

PHALO COI.PORATION

PHALO CQTPQRAT

PHOTRONICS

POMFHET RESEARCH OPTIES IMC

PRECISIDN QUARTZ INC

PRENTICE INDUSTRIAL SUPPLY INC

PRISHS UNLIHITED INC

Jich conp

DOHID OPTTCaL CORP

GUANTA-RAT

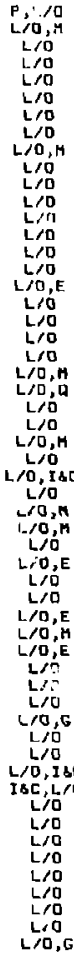

IHTERFACE

CYL WINDOWS/FUCKET CEL-S

FIEER SYSTEM

MODULATORS

MODIFY OPT ICAL PYRP

$\begin{array}{ll} & 60104 \\ & 95003\end{array}$

C. 05353

46103

CHASEIS SLIDES UNIT \& LENE

REMOTE CAMERA UNIT \& LENE

CYLINDER LENS

CYCLINDER LENS 60618

DPTICS MDUNTS .

DUDSTRATE. OPTICS

PRPOR SUPPLY

11410

92705

11247

06810

LASER MPTICS $2 "$ "MIRRORS

REPAIR OF FIZEAU WAUEHETER

POLISHER, GRINDER

ROD, TANTALUH, GINGLE CRYSTAL

C TARGETS

LASER/METER, RADIATION

FRIT FI:TER

TISTATER SUPPORT/LASER TAELE

CELLS, FLUORESCENCE.

HAGHETIC SHITCHES

CUL LENS CDAT/HIRAORS FDR RELULJS

ACHROMATIC LEVE TAKP COMPONENTS 91773

PHOTO DETECTORS

MIRROR MDUNT

LASER EYEWFAR

HTGRDHETER SYSTEM

MIRRQR MTS, BEAM PHDC. TABS

ION GUN/ELECTRON GUN

ION CUNJELECTREN GUN 95119

OPT ICAL INTER FACESOPTIC FIHERHULT IPLEXER

CVL OPT ICAL DELAY DEAH

11788

CTM LASER

OPTICAL POLYCAREONATE SHEEIS

OPYICAL

PR ISNS

CDRHER CUAES

LASER / CRYSI ALSIE TALONS /REPAIR LASER

95050

95205

92640

02154

94043 
REFRACTIRY PRDDUCTS CD ROCKWELL INTERNATIOKAL

ROLYN OPTICS CO

RTRON CORP

SANDR INC

SCHOTT GLASS TECHNDLDGIES INC SIGMA REGEARCH

GHTH REgEAR CH

SNI

SPAUA OPTICAL RESEARCH

SPECIALTY ENOLNEE

SPCCTRA OP TI

SPECTRA-PHYSICS INC

SPECTRO-FILA

SPHIKOA

STANDLER INC

TECOPTICS

TINSLEY LAES

TITAH TOOL SUPPLY

TWO-5IX INCORPORATED

UNITED STAYES FUSED
VALLEY MACHINE SHDP

VALLEY

VALTEC

$g$ UAVETEK-SCIEH

WAVETEK-SCIEA

HESTERH PIPI

WILLEY CORPORATION

WYKO OPTICAL

ZYUO CORP
L/O ACM LASER

L/O MICROECOPES, OBJECTIUE

FILTERS

LENS HOLDER

BLANKS, 18 "

BLAPYS

19642

DISCE, OUARTZ OPTICAL GRADE

DISCE, QUART OP JCA

LASER GUGCLE

FILTE

FILTERS, CENTER WAUELENGTH 01890

TEPPTR 03055

TELESCOPE

GOLID ETALONS

CUL TELESCOPE ASGEMELY 74710

GORESCOPES 14216

MIRRORS 16056

QUARTZ TUBES $\$ 4006$

BCN LASER

POSITIDNER ASSY.

SOLID ETALDNS 33569

FILTER, BAHDPASS BR ICKWALL 07647

SLUG FEEDER/LASER ASEY

REFLECTANCE SAMPLES 
UENDQRS - MECHANICAL

\section{A \& $K$ MFC}

A F EQUTPHENT CO INC

a $\mathrm{H}$ CASTLE CD

A H RESEARTH

ABEEON CAL INY

ACCD INDUSTRIES IHC

ACCURATE MFG CO

ACCUR IDE

ADEPT HANUFACTURING CO

ADF SERUTCE CORP

ADUAHCE CAREON PRODUCTS INE

ADUAHCED INSULATIOHS REFRACTORIE

ADUAHCED TECHNOLOGY CO

AERO-SPACE HEL TIHC CO

AER DMET INC

AERGHET INC

AERUSPACE

AF EOUTPMENT CO TNC

AF EQUI

AIR TOOL ENGIHEERING CO

AIR FILTER CONTROL INC

AIR FO

AIR PFODUCTS \& CHEHICALS INE

AIRCO TEMESCAL

ALASKAN COPPER \& BAASS CO

ALASKAN COPPER \& BA

ALCATEL VACUUH PRODUCTS

ALKURT METAL, INC. ALLL WELD MACHINE \& FABRICATION CO

ALLEN P JAHE

ALLIED ANALYTICAL SYSTEMS

ALL IED ENGINEERING

AL HAC CRYOTENTCS IHC

ALHAC CRYOGENICS INC

AMER: IAN SCIENTIFIC PRODUCTS

AHFAC PIPE SUPPLY CO

AMPLEX CURP

ANALABS INC

ANDERSON TOOL ENGINEER ING CO

ANSUL CO FIAE PROTECTIOH GROUP

APEX MACHIHE TOOL CO

APPLIED FUSIOS INC

APPLIED OPTICS IHC

APS-MATER IAL

AP SCD MANUFACTUR ING

ARD CORP

ARROH FASTMERS

ARROW TANK WORKE

ARROH WEI.DING

ASBDCIATED MACHINE

ASSOCIATED SPRING BARNES GROUP INC

ATLAS METAL SPRAYING CO

DETE.CTOR base PLATESCOHSOLE FRAME

FILTER HOUSIHG

ANGLES

CLAMPS FOA LINEAR AMP

HELLOWS

JTB CRANE

REGULIS RIELION POST BACKGROUND PLATE

SLIDES 20 "

HEPA-FILTERS

HEATER PARTS FQR REGULIS

PRODUET PLATE RELORK

INSULATING CYCLINERS, ALUMINA

VIDEO MULTIPLEXER/COLLIIMATOR BASE \& PLAIES

DUAD CLAMPS \& KASE/ACM OSEILLATOK

TAHTALUM TUHES

CLAMPB

FLURR SHIELDS, MTNERUA

FILTER HIUSTHC

VACUUM FURHACE

HOI ET

HEPA FILTERS

CRYOPUM GYSTIEM

BELLOWS

HEAT EXCHAHCER

EXINULATOR

PUMP

HËTAL FAB TO PRINT/SPEC

CHAHEEA NECK ASEY

NEGUL TZER, TORCH S SPRAY CHAMGEH

NEEUL TZER, TORCH \&

GENERAL. FAER ICATION

COLUMMS

LIQUTD GAS CYLINDER

TRITON BEAH ENC/ALUMINUM CASTII $: 9$

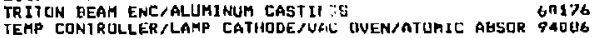

FITTINGS, DYE PIPE

DAILLS A CORES

COLUHNS, ALUMINUA A STAINLESS

QUAD MIAROR HOUMI

NT TROGEN CARTRIDGES

SOCKETS

THOR COOLING JAC

LASER HINDDW

PLASMA SPRAY

HAND KNORS/FAN FEEDTHROUGH

WRENCH, IHPACT HEUEKSIE

SEREUS'

FUEL TANK, $2 B O$ GALS.

FLOHMETER I:AR WELDER/SHOP CURTALN

DPTICSS SUPPORTS

SPRIMLS

PLABMA SPRAY IIN POLY SHEEIS
Y4601

94043

94544

93101

$945 \%$

94550

40670

9408

94612

95035

07631

75035

74043

17207

94002

95050

10405

18102

\%?5

90124

84036

94006

c4938

9.



8450

950.35

06002

06473

4601 :

5414

Qnisut

84577

94523

45405

91749

94544

YoD0\%

44621

95050

1424 
Ays

H I SPRAY EQUIPMENT CO

HAL BEAL ENETHEER ING CD

GALL SCRENS ACTUATORS CD INC

BARSTAD DONICHT INC

BALMANN HAND

BAY BOLT INE

BAY CITIES TDDL SUPPLY

BAY PNEUNATIC INC

BAY RU INC

EAYOX INC COHPANY

EEEMER ENGTHEERTHG CO

BEIMER MAC,MINE LORK

BEL ILQUE CD

BELLOFRAM CORPQRATIUN

BEN W BRUNDAGE CO

BEST TOOL MFG CO IHC

BEST TOOL HFG CO IHC

BILLINGTON WELDING CO INC

BOEKE INDUSTR IOS INL

GRANSDN CLEANINC EQUIPHENT CD

ERIDCEPORT i

GROOKS PRODUCTS INC

EROWN, NOEL $J$

ERUEL \& KJAER INSTRUMENTS INC

ERUSH-DELLMAN INE

GUULLER PKECISE GALES CD INC

BUEHLER LTD

BURKE CO

C D 5 ENG INEERING INC

C H EULL CO

C H DISTR LEUTING CO

C L HANM INDUSTRIES INC

C U C PRODUCTS CORP

CW WARREN CO \{AITSO DIV\}

CAL MAR PIPE

CAL PRECISION MFG CO

CALIFORKIA EUILDERS HARDJARD CO

CALIFORNIA INBTRUMENT CD

CALIFORNIA SERUICE TDOL CORP

CALPACIF IC EQUIPHENT CO

CASHCD INC

CASTLE PLASTICS

CE PROCESS EQUTPHENT CORP

CERADYNE INC

CERAMASEAL INE

CHALET TOOL EO

CHAMP $\mathrm{CD}$.

MEATING FLEMENT/HEAT FHIELDS

SPRAY GUN PARTS

MADIFY TURBO-PUMP

FAE'D STORAGE RACKS FOR GAS CTLIHDERS

SIDE LDAD FIRKLIFT

GOLT SETS

FASTENGR

CASTINE

OIL REMOUAL FILTERSPUALUES

WIHDUU CASKETS

WIHOUL CASKETS

COUPLINGS

HPL DOOR LATCH PLATE/CHAMBER COLLECT

THEKHOSUITCH/CINTROLLER SCR/HEATERS

SEALS

KE'YSTONE VALUES

TAM process tag

LIFT TRULK

CRYSTAL RETAIMERS

JRY

PUMP PARTS

REFR IGERATIDN UNIT/SOLUENT REU ST:LL

MILLING MACHINE HILLING HEADS

CDNERETE TABLES

ER-DOR-FURHACE

SHAKER EQUIPMENT/AMPLIFIER, CHARGE

SPECIAL MATER IALS

FEED MOTDRS

DIAHOND SAW GLADES \& ASS

COUPLINGS SCISSOR CLAMPS

REPAIR PZ-70 ATPSIMIRRDR MOUNTS

EXTRACTOR CDOLINE ASSY

HEAT EXCHANGERS

STORAGE RACKS

COOLING PAN

COHIVALEA

FASTENERS

HEAT SHIELD SIDE/COLD TAAP UESSELS

EIASE, COUER, LIDE \& PISTOHS

DOORE M1NGES

UALUES

ADAPTER/ORIUER KHDEKUDI KI I

HARK UIII FITTINGS

RECULATOR, GAS

PEDESTAL TUE

GEADS, CLASS /GFIT BLASTER

CEFAMIC ERAKES

VACUUM IREAKS

ARCHS

INJECTION LOCK

TELESCDPE ASSY/COLLECIUR TANK

92707

45113

Y4675

00500

60560
94577

74560

74560

$9457 \%$

94621

94621

14039

19034

9566

44503

OABם

94611

$9457 ?$

64113

94401

95352

95132

19106

75131

92714

94531

94503

45008

72005

44190

$7 \mathrm{C} 029$

6004

$P 4000$

14453

75212

94080

53204

45126

94069

40038

94601

45035

Q4id?

44124

94577

94710

Y450

94566

94506

92794

liisto

1icted

440

Th 
VENDURS - MECHANICAL

CHASSIS TRAK

CHICAGO ERIDCE * IRON CO EHROMALOX

CTRCLE EYSTEH

CIRCLE E SY

CITY TOOL-DIE \& MFE CO

GLARKLIFT IOAKLAND

CLIPPER INDUSTRIES INC

CDAST MARINE \& INDUSTRIAL SUPFLY

COAST TOOL CD

COAST TCOL CD

GOKER PUMP

GDLE PARKEA

COLEX YNTERMATIOHAL LTD

COLEX YNTERKATIONAL LTD

COMPUTER AIR,POWER SYTTEMS INC COMPUER AIR

\section{GONAX BUFFALO CORP}

GONAX BUTTAL PLASTICS \& CHLHICAL

CONTRA COSTA BUILOERS HARDWARE

CONTRA COSTA BUILDERS

COOKE VACUUH DRODUCTS THC

COOKE VACUUH

COSMUDYNE

CQULTER STEEL \& FORGE CO GRA'IE CH PUAF

CRANE GERUICE CIRPORATION CRYSTALLINE CONTQURE

\section{CTI-CRYOCEHLCS}

D \& M MaCh LN

D C TOOL CO

DANFORTH SCREW \& BOLT CO

UATA DPTICS INC

DAUID J TR IPP AESOCE INC

DEAN LEWIS ASSDC

IEFIANCE TODL \& DIE

DEL-TRON PRECISION INC

DEUAUL. T

DIAMOWD DEUICE

DIAHDND TOOL $\$$ DIE IMC

DIATECII DIAMOND TOOL CO INL

DO ALL SAN FRANCTSCO CO

DOUGLAS ENGINEER ING CO

DUHIG Ca

E 2 WARD 60

E F NORHAK ASGOC

EAGEL-P ITCHEG INDUSTRTE:I IHC EARLE M JORGENSEN CO

EAST BAY PUH \& EQUYDKEYT CO EATON CORP

EDM EXTJTICS

EDLARDS HIGH VACUUM INC

EJ \& $F$ ENGINEE

ELECT AIR TCOL CD

ELECTRO-FLEX EAT INC

SLIde mechaniem s Frackeis

$\begin{array}{ll}\text { SLIDE MECHANIEM S FRACKEIS } & 46239 \\ \text { VESSEL } & 94104\end{array}$

HEATERS

Puxps

VALUES

STPPLRT 75050

CCISSOR LIFT

60143

HANLIFT

COP THE SYSTEM

COOLING SYSTEM 94607

HLA TAPES C

HEO CODL GAS C

DR ILL PRE 39, BENCH TUP S06.3\%

AC UNIT

WATER SOLENOID VALUE

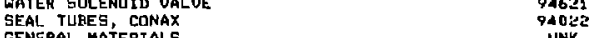

GENERAL MATERIALS UNK

TAELE TOP

TAELE TOP

$\begin{array}{ll}\text { CRYDGENTC ANYIMIGRATION TRAPS } & \text { OI746 } \\ \text { FILTERG } & \end{array}$

LOOLING SYSTEN 90500

COPPER FORGING/STEEL TUOL 94663

DYHAPUMP 97523

CRANE

CERAHIC BTANDOFF/ CREATER SECMENT PUMF

CRYCERS \& NOUNTIME PLATES

NIKE DOCR SUPPORT

SOCKET SET $\quad 94070$

FILTER HOLDERS

TEM GAE FILTERS 9:201

HANDLES 94545

CLAHPS, RETAINERS A FLANGES FOR OPIICML ERCLUSURE 9453B PDSIT TONERS MASTER OGCILLATOR EASE 35805 HEAT EXCHANGERS COLLIMATOR/HPLLF CRADLE ASTY DR ILL CORE

CONTBUR SAL

BULKHEAD CDNNECTORS, FEEDTHAU

DYE LOOP UNTONS

HEAT PUMP

HEATERS

CERAMIC PAPTS 74363

CENERAL MATERIALS

PUMP

OSC, IUBING TDEKITRON, 9409

GLIDE SHAFT/RIBBUN SUPPOHTS

YIBRATION PAD ISOLATORS YOST"

HDT AIR SYSTEM

TUBE FITTINGS

HEATERS OUUO" 
ELECTROFUSION CORP

EHI PRECISION

ENGELHARD CORPORATION

EQUTFTO ELECTRONACS CORP

ESCO CORP

EUTECTIC CORPORATION

EUANS PRECISION MaEhIHINE

EXERCY INC

EARDO ENGINEERING INC

FALCON INDUST

FALLON ENGIN

FENHAL ELECT

FERKUFLUIDICS COR

FIL-TECH INC

FILTREX INC

FISHER CONTROLS INTL INC

FLANDERS FILTERS INC

FLEXICRAFT INDUSTRIES INC

FLOU TECHNOLOGY INC

FLUID KINETICS CORP

FLYIHG MACHINES

FORCE ELECTRONICS

\& FOX INDUSTRIAL SALES CO

FRANCIS PLATING CO

G D W EUPFLY

GARDHER HACHIHE PRODUCTS

CATELY STAINLESS \& PLLOY CO

GEM CITY SPECIAL MACHINE UUILDERS

CEMERAL FIGER OPTICG

GENERAL THDUSTATAL GALES

GEHERAL MACHINERY IND SUPPLY CO

GENERAL MACNAPLATE-CALIFDRNIA

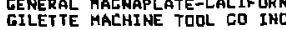

GLENDO CORP

CLENDO CDRP

GOLDEN PLASTICS CORPORATION

GOULDS PUMPS INC

COULOS PUTPS INE

GRANT SUPPLY CO

GROENIGER \& CO

GROENICER \& CD

H HACHIWERY

HABER AIRCRAF

HAHILTDH TDOL ENGINEER INI

HANF ORD ENU.

HARBOLD GEAR

HARDCAETLE ENGIMEERING

HARDTMGE BROT'.EFS INC

HARR INCTON INDUSTRIAL PLASTICS

HARTHELL. CDRP

HEAT SYSTERS ULTRASONICS INE

HEATHS UELDING SUPPLY

HELICAL PRODUCTS CD INC
WELD, ELECTRDN-BEAM

-1 MMDUNT

PT CRUCIBLE/THERWOCDUPLE

RACKS, VERT. ELECTR

NELD FITTINCS/TUEES AITTINGS

WELD SUPPLIES

OSCILLATOR COUERS \& GULDE WLATES

PUTP RECHAHGER

PUMp REPaIR

GEFEAAL FAERICATIONS CLOSED LOOP PUHP

THERHISTIR

ROTARY FEED THRL

DIL DIFFUSIOH, PUAFS

FILTER HOUSINAS

SPACERS ASB.STOS

HEPA FILTERS

RESEKUCIR

RECALIBRATE FLOWHETERS IN MAHE CUILING

DAMPER FILTER

DETECTOR BASE / CAPACITOR SUPPORT

CRIMPIHG TODL \& TERHINAL

ELECTRIC HOIST

CRUCIBLE HOUSTML PLATING

GRAPHITE PLATE

JET PUMP B EJECTOR PACKAGE

INSULATOR, LOWEX

LATERALS

GRAPHITE PARTS

OPTICAL FIBERG

GENEFAL HATERIALS

MILWAUKEE DRILL

LASER ITUTN 5 /COATINGS, HJ-T-LUS

LENS HOLDE'RS, HOUNTS \& GUIDES/CLAMPS

TOOL SHARP NER

GAS CHOKE ASSY.

GENERAL FABRICATIONS

TEST PUMP

DYE LUOP VALUES

GRAPHITE VANES/CRUCIBLE

HAF CAST IRON FITTINGS

SUPPORTS FOA SPECTROMETER

LATHE CHAHGE GEARS

CLAHPS

RORESCOPE MOUNY

HEPA/HSA FILTERS

SLIDE GEARS

UACUUM SYSTEM

LATHE PARTS

DE 'ECTORS/PUMPS

HINGES/LATCMES

SCRUGUER SYSTEM

GRINDING WHEEL/SHOP TROLS

COUPLINES
94025

07000

60507

94608

94621

9

94002

75125
94537

74533

01701

03061

믄1

74545

94401

27889

60612

95036

7300 ?

74550

55051

54103

94607

90242

94550

95122

Q4124

45401

07006

07006

94540

93003

14624

66801

50915
94603

94603

ग4598

94510

94025

94540

74566

94538

90245

91214

99352

94002

95119

94043

99710

92670

95129

94568

93456 
VENUORS - MECHANICAL

COMPANY NAME

HELLLMA LELLS INC HENRY PRATT INC

HESE GREIHER \& POLLAND

HEUSSER INSTRUMENT CO

HIGH VACUUA APPARATUS HFG CO

HICH UACUUH EQUIPMENT CORP

HILTI INC.

HITCD

HDART CDRPORATIOA

HOPPER INC

HPS CORPQRATION

HR MACHINER Y

HTE :NC

HUMBOLT INSTRUMENT CO

YUNTINGTON MECHANICAL LABS

HURCD MFC CO INC

HURCT LABS

HUSSHAN CORP

HYSPAN PRECISION PRODUCTS INC

INDUSTRIAL ELECTRONIC ENG INC

INDUSTRIAL TECTONICS

INDUSTRIAL TOOL

INABAD

INSTRUMENT L

INSTRUHENT SPECIALTIES COMPANY INC

INTTRUENTS $S$ A INC

ISOLATION DESIGH INC

JAED ELECTRONICS INC

JAHES WILBEE CO

JEARY EARRDLL HACAINTHE INC

JESSOP STEEL

JCLLIFF ENG INEER ING CORP

JUNATHAN MFG EORP

JORDAH VALUE

JURCEHSEN SY

JOSEPH T RYERSON \& SON INE

KAYAN BEARING SUPPLY CORP

KC PRECISION SHEET METAL

KEEHNER HTG CO

KEEN-KUT PDEDUCTS

KEHLON PRODUCTS \& DEVELOPHENT CO

XENHAHETAL INC

KEWALMEE SCIENTIFIC EQUIPHENT COK

KEY PIPE \& SUPPLY CO

KILSUY ROEERT

MIN-LINE INE

KING BEARING INC

KORFUND DYNAMICS CORF

KURT I LESKER CO

L. \& F IADUSTAIES

L O SCHUELKE CO IHC

L WALHEIM ALSOC

LANG ENGINEER ING EQUIPMENT CO

LANCNETIC TOOL CO

LECO CORP

LUDE

ITEMS PURCHASED HY AULIS

$Z I H / P O$

DYE CELLS

FUTTERFLY VALUES

HEATING CDILS

HAL ANCE $A$ TAHLE

UALUE [FATES/CONFLAT FLANGES

VACUUM SYSTEH

FASTEMERSISHOP DRILL

REDUCER, PRESSURE

METAL SHELUES

GENERAL MATERIALS

PIPE FITTINGS/GaTE VALVE

LATHE \& ASS

GREAKER/LASER MOUNTS

REPAJR MILLIAS MACHINE

FLANCES \% GASKETS

COOLING SYSTEH

EXPANSION JOINT/BELLOWS

PER IPHERAL ENTRY PANELS/POLER SUPPLIES

FIXTURE \& CHECKING BALIS

GR IND WHEELS

CUL UINDOWS/POCKET CE:LS

FITTINGS

SPRING STRIP, FINGER CONTACT

GRATING/PLASMA TORCH/HOLDCRAPHIC GRATIMI

CONHECTCR HU/TERHIMALS, CAELLE

GEARIIOX

VACUUH PUMP

SUFPUK IS A SHIELDS

GEWERAL MATERIALS

ELLOWS ASSY'EXPAMSION JOINTS

STEEL TOOL, G"\%

Q PLATES

LIFT FRAHE

CHTROL FOX

CONSOLE FRAME

DRILL SORE/DIAMOND WHEELS

TURGE PUAP KIT

TOOL HOLDEH \& TOOLS

FUME HOND

FLANCES

TUEING $P$ P P IWE

SUPP OH TS

TAPER LOCK

UACUUM PUMP HOUNTS

VALUE/UAC. EQUIP

GENER L FAER ICAT IONS

HEAT EXLHAHGER

SLIDE Far LASER cakINET

PROCESS PUHPS

FILTER HOX

POL ISHER，GR INDER

11424

94523

94517

74545

02043

74577

94577

93303

94545

44043

46260

94043

UNK

92102

4 19106

95112
07647

94394

94301

18327

94006

95131

8 .

846,33

94623

94600

94577

84538

94572

94810

27021

90701

94765

84623

74544

94606

94536

11590

84550

90802

94070

94002

$9454 a$

94070

Y2705 
UENUORS - HECHANICAL

LEE SPRING CO INC

LEYBOLD-HERAEUS YACUISM PRODUCTS INC

LINEAR INDUSTRIES LTD

LINHEY CO

LIVERMORE. CONMUNICATIONS INC

LMC ENTERPRIZE

LYRU EHGIMEER INC \& MANUFACTUR IHG

LYTRON INC

$M$ AND $W:$ :STEMS

MACHINERY SALES CD

MACHURRAY PACIFIC

MADRUEA IROH WORKS IMC

MAGNET SALES \& HFG CO

HAGNUT INDUSTRIES

MANOR RESEARCH INC

HASTER APPLXANCE

MATH AGSOCIATES INL

MATH ABSOCIATES INL

MCLAUCHLIN ASSOGIATES

HCMAHDN' $G$ WELDING FABR ICATIDN

MDA BLIENTIFIC INC

MDC MANUFACTUR ING INC

MEADOWS MANLIFACTURING

MECHAHICS TDOL \& SUPPLY T.O

MELATX CO

HELLEN COMPANY INC

HELLES GRIDT (LASER PRODUCTS DIU) HELROSE HETAL PRODUCTS

HERCOIN CORP

HETAL BELLQW CORP

METAL GOODS

MEYER MACHINERY CO

MEYER TOOL \& MFG INC

MG LUCKE RUEBEH CO

MICRO-MO ELECTRONICE

MTCROPUHP CERP

HIDDLETON IWELDERS SUPPLY CO

MILE TECHNOLOGY INC

MILLIGAN-SPIKA CO(IND SALES DIV)

MILLIPORE CORP

MILTON 5 FRAMK CO INC

MIHARTK ELECTR IC CO

MINE SAFETY APPLIANCES CD

MTMOR RUBRER CD INC

MIROU-TRANE GERUICE AGEMCY
MKS INSTRUMENTS INC

MKS INST UMENTS INC AGENCY

MONARCH PAN PACTF IC FASTENEA CD

MONTERREY MECHANICAL C

MONTGOMERY RR

MODRE HANDLEY

MODSHAN TOOL

HOTT METALLURGICAL CORP

HULTI PLASTICS

GALL SCREHS REUORK

GRACKET DIDDE \& UASE PLATE/HELL JAR SUPPORT

RADIATION EHIELDS 9457?

CHILER SYSTEM

9454

HILLING HEAD, BHIDGEPORT , 94022

. 94103

MALNET PARTS

GDCKET, ADJUSTABLE

SPRINGS FOR OSCILLATUR

TOREH KITS HEATIMG ELEMENTS

MUUNT CDUEK \& BRACKET /DRIVE SHAFTS

OPTIC FIBERS

DYE CELL BASE, CLAMP \& FLOW DIUERTER 64129

EXHAUST FAH

STAND \& SPACER

HOOD, DUCTLESS

TUDES/UALUES, PNEUMATIC GATE 60025

THCK ACCESS DORTE 94545

$\begin{array}{ll}\text { CONSBLE, TRACK ACCESS DOOR } & 94088 \\ \text { GPRING PLUNEERS } & 94621\end{array}$

LDDS

QUAATZ RETENTIDN PLATES \& HARDWARE

GENERAL FAHRICATIONE

PRESGURE SUITCH

BELLOWS 6"/FLEXHOSE

BRAZING ALLOY 97877

94063

TEST FIXTURE STAND PIPE

D RINGS 95000

GEARMOTOR

MAGNETIC CUPS

94577

FILTER SYSTEM, UAPOR RECOUEPY

COOLING LJNES VESSEL ASS 74621

FREON CLEANING VESSEL \& ASS. P4UBO

STEP MOTORS

STEP MOTORS

GASKETS, TAB W UNDOW

AIR COUDITIONERS S AIC UNIT SEYUICE

VALUES,PRESSURE \& CONTROLS/REPAIR OF MLLTIPLEXER 94022 ANCHOR BOLTS 544623

GENERAL HATERIALS, \$4621

FJLTERS, raRTA MEE \& HOUSIN, 94020

GENERAL HATER IALS 35051

MOTOR MOUNT GELDMENT/HOUSING 9500 -

DRUM DUMPER FOR CRUCIBLE 13057

MAG. SIIIELDS/DIODE CHASSIS 
MUESER ASSOC TATES IMC NAT IONAL TANK $\triangle$ MFE

NED-TECH SPRINE CORP

NESLAB INSTRLIHENTS INC

NELPQRT CORP

NILEB MACHINE \& TOOL WORKS INC NOOTER CORP

NDA CAL SUPPLY CO

NOR-CAL METAL FABR ICATORS

NOR - CAL PRODUCTE

NOR-CAL PRODUCTE

NORTHLEST UICRONITE

NORTHES UTCRTE

NRC INCORPORATED

NFC INCORPORATE

HSG AKER I

NUCLEP ORE

DAKLAND VALVE \& FITTING CO

CAKLAND VALUE \& FITYING CO

OPTICD GLASS FAERIEATION INC

ORANGE CQUNTY HACHINE UQR

PACIFIC COMBUTSICN ENOINEERING CO

PACIFIC BCIENTIFIC CO (BELFAB DIU

PARAMOUHT haWUF ACTURiNe CO

PAT PATTESON AGSOC

PAUL HUELLER CO

PAUL-HUNRUE HYDRAULICS INC

PENWALT CORP (BTOKES DIU)

PIC DESICN CORP

PIEZO ELECTRIE PRODUCTS

PLASH-THERH INC

PLASTIC GERUICE CENTER MFC INC

PNEUMATIC ENGIMEERING

POCD GRAPHITE INC

PQLLARD TODL \& MACHINE CO

PDLYTECH CD

POST LIQUIDATI

POUER MACHINE CO

PPG INDUSTRIES INC

PRECIGION INDUSTA IAL CERAMICS IRC TRIMCETON AF

PAIZ-CD INC

PRO-DESU MFG INE

PROCESS EQUI PHENT CORP

PROCESS VALUE

PROTEUS

QROTEUS

R 5 ERECTION

R L PRODUCTS

$R$ W STADLER INC

RADECO

RAPJDSYM CO DANA
RICHMOND LOX EOUIPMENT CO I RICHHOH

RICHMOND LOX EQUIPMENT

FOBUOH BACKI

INSULAT ION/TABLE HOIST

GENERAL FAFR ICATIONS

WATER COOLER

MIRRORSPGPTIC HOUNTS/LASER SUPPORT/LAEER TAELE 92708

gDX PLUHEING

VACUUM \& PREGEURE VEGEELS

GASKETS FOR PUMPS

GLOUE FDX HARDUARE

D RINGS

DYE CELL Bages \& CLAHPS

FASTENERS

SUPPORTS/CRUCIBLES/E-BEAH GUN

COLL IMATOR

COLLIMATORS/CELLS, FLLORESCENCE

HATER FILTERS

STAINL

LASER WINDDUS

HEAT ING ELEMENTS

BELLUWS

GENERAL MATER IALS

UALVES, GUTTERFLY

COOLING PANELS

CLAMPS

UACUUH PUMP PARTS

LEARS/MOTOR COUPLINGS

FANS

PLASMA DEPOSIfION BLOWER PaCKaGE

GENERAL MATERIALS

PUMPS

COLLECTOR HE.ATINC ELEMENT/SHEET GRAPHITE

LAEER TAELE FRAHE

PIPELINE

SANDINI MACHTNE

GENERAL MATERIALS

GENERAL MATERIALS

INSULATION CLAKPS

BEAH PFDCESS TAB

PUMP FILTERS

TIE DOWH BRACKETS

TANK, PERMAHENT TRANSFER

AUTOMAT IC VALUES

FLOW SUITCH

REPAIR OF DYE CIRCUI :

DOOR, ROLL-UP

RINGS

LQCKS RUMP /UACUUM PUMP

94560

63100

$9455 \%$

94607

01836

94040

97321

0264

07066

94568

94712

94523

93030

90132

32020

94608

94903

94560

6581

9505:

91746

91416

088an

95131

95050

$9003 \%$

76234

99997

84063

94607

94608

15222

95050

95008

an?

48309

07033

$\$ 4041$

94043

94566

95603

92121

STEP MOTOR

VALUES, RELIEF/REGULATOR, CYRO

90870

94550

97031 
ROSE ELECTRONIC

ROTH PUAP CO

RYAN HERCO PRODUCTS CORP

SAN FERNANDO LABS

SAN FERNANDO LAES

SAN JOSE SCIENTIFIC CU INL

SAN JOSE SCIENTIFIC CU INC

SANTA CLARA MACHININC CO

GARGENT INDUSTRIES

SARGEHT UIELCH SCIENTIFIC OF CAMADA

SAUTER DIV

SCHUARZKOPF DEUELOPNENT LORP

SEAL MASTER

SELUAY HACHIHE TOLL CO

SEMIUAC

SERRA CORH (HACHINTHE DIU

SHELLEY ELECTKUNICE IHC

SIEBERT MACHINE PF JDUCTS INC

SIECOR CORPORATION

SKYLINE DISPLAYG INC

SHITH CLARK

SHITH'S PRECISION TOOL WORKE

GNL INC

GNAP-ON TOOLS CORP

SOUTHCO INE

SPACESONIC INC

SPOKANE METAL PAODUCTS

STACKPQLE CORPOKATION

STAINLESS EQUIPMENT CD

STANDARD BELLOUS CD

STANDARD STRUCTUREB INL

STAR PRODUCTS

STEAH \& PLUMBINT SERUICE CORP

STERL IHG INS

STONEMAN ERUIFHENT CO

STONEKAN EQUIP HENT CU

GTDUE PLUMBERS SUPPLIES
GTREETHAN PRECISTON TOOL

SUNSTRAND DATA CONTROL INE

SUEDLOU INC

SUEDLOU INC
GLEPCO TUAE CORP

GYMTHANE-TAYLOR

GYNTHANE-TAYLQR
TAP PLASTICS INC

TAP PLASTI

TECHNICAL DISTRLEUTOHS INC

TECO

TEMPCO EQUIPMENT CO INC

TEMPRESCD IMC

TERHINAL MANUFACTUR ING CO

THERHCRAFT INC

THERHXONICG LAEDRATORY INC

THERMD ELECTRON CURP TEGERLINE TNST

94010

61201

91503

98331

95112

94593

95050

55068

60076

74566

90045

11746

44240

$945 \mathrm{~B}$

950.35

94530

94043

95000

20603

55337

94025

74608

94566

94566

94600

74545

94063

95076

99100

$\$ 9100$

15827

80110

06096

$9540 ?$

95103

9 a103

11040

94520

95052

95692

94130

94105

90200

07000

19456

$945 \% 7$

02146

91356

94063

94005

94560

$\$ 4103$

27107

Y4542

0186\% 
VENDQRS - MECHAHICAL

THUMAE A SHORT CI TICO TI TANIUH INC TIGER AIRBRLSSH CO TIGTECH INC

TIHE ELECTRONTCS NOR /CAL TITAN RUEFER \& SUPPLY CO TITANIUH ENC

TOCCO ALABAMA IMC

TONY'B MACHINE

TORR VACUUH PRODUCTS IMC TRANE CO

TRANSAMER ICA DELAVAL INC GHARKSDALE TRI TOOL

IRIAD DIE CAETING

TRIMETRIC SPECIALTIES

TROYER DOUR

TRU (CUSTOMER SERUICE DIU)

TURNOHAT

U-C COMPUNENTS

ULTRA CAR BUN CORP

UNBRAKD

UNITED ETATES PLASTIC CORP

\& UNITEK CORPORATIOH

UNIUERSAL EQUIPHENT MFG CO INC

UNIUERSAL MAGNETICS INC

US INE.

YACUUH ATMOSPHERES CD

VACUUH GENERAL

VACUUH RESEARCH MFE CO

YALLEY PRECISION HFG CO

VALTEC

VAPONICS INC

VEECD INDUSTR IAL ERUIPMENT DIU UELHEX INEDRPORATED

VENTROD CORP

VIKING DISTRYEUTING CD INC

UIKING METALLURGICAL COK

UIKINE SPRAY EOOTH INC

UISUAL METHODS TNC

U \& PLASTICS

H \& M PLASTICS

WACKER DEUELOPHENT INC

WALDOH DAFFY IHC

WALE APPARATUS CO

WALL COL HONOY CORPURATION

WATLOW ELECTR IC MFC CO

WEAUER INDUSTRIEG INC

WELK BROTHERS METAL PRODULTS

WEST COAST METAL SPIHNING

WESTERN KARDUARE \& TOOL CO

WESTERH MECHANICAL CO INE

LESTERN PIPIHG \& ENCINEERING CO

WESTERH RUBBER SUPPLY INC

RUIAER EOOTS/ENCLUSURE SPONGE CASKET

94662

TITANIUH BOLTS

ALRBRUSH

CONNECTORS $\$$ CLAMPS

TANTALUA FAGTNERS

WOAK STATION

ANEHDR PLATE

REEUILD GELLOWS

HANDLING UNIT/HEAT PUMP

PKESSURE SHITCH IOVE TRANGDLCEKS $90 A 70$

LATHE ACCESSORIES $9567 \mathrm{~V}$

GLOUE PDRTS

BEAM PEOCESS TAS 9456

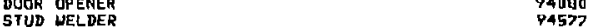

HALL BEARINGS

SCRELS

EXTRACTMR PNLSI SEC UPDATE 94043

FASTENERS

FLOH GUTCH

PEWER AMP MAT

SPOT WELDER

GLUUES, CRIS BLASTER

UALVE H HETER ASSY

VALVE HEATER ASSY,

DRAIN PURIFIERE VACUUM OUEN S CHAMBEA

CONTROL HODULESFCOHTROLLERS/POLER SUPPLY A CABLES 9a111

$\begin{array}{ll}\text { GENER AL MATER IALS } & 94583 \\ \text { DEHYDR IDINE FURNANCE } & 96025\end{array}$

$\begin{array}{ll}\text { DEHYDR TDING FURNANCE } & 96025 \\ \text { POSITIONER ASSY. } & 94523\end{array}$

$\begin{array}{ll}\text { POSITIONER ASSY } & 94523 \\ \text { WATER STILL } & 02360\end{array}$

WATER STILL

ASSEHBLIES, PRECIEION LEAD SCREW

ASSERELIES, PRECIBION LEAD

THERKAL SEALI

HAND TOOLS

GPRAY BOOTH- INCLUDES INSTALLAIION

GRACKETS

GENERAL FABR ICATIOJNS

GENERAL HATERIALS

WASH TANK PARTS

ELECTRAN ELEMENTS

GASKETS

MICROBRAZ

HEATERS

EXTRACTOR PANELS

GENERAL FAER ICATIONS

FLANGES FOR FILTERS

TOOLS

FAN, COIL

SLUC FEEDER/LASER ASSY

CASKETS

10067

91723

11234

94107

74162

95035

07675

9240 0

24301

94622

93008

94107

18055

462A3

63141

96214

94550

94107

94549

$9412 A$

74124 
VENDQRS - MECHANICAL

COMPANY NAME

CODE

ITEMS PURCHABED KY AULIS

WESTERH STATES

WESTERH UHDLESALE DISTRIEUTOR

HHDLESALE BUILDING SUPPLY INC

WILCO SUPPLY

WILLRIEH ENGINEERIAG CO

WIMFRED I BERG INC

WOOD HORKS

YALE IMDUITTR AL TRUCKS

YOQK TELTTRAAL TRUCKS

YOQK WELDERS SUPPLY INC
ZIRCAR PRODUCTS INC

SUMP TANK PUHPS
M DUCTWORK

LOCKS

LOCKING DEY, DOOR/KEY FOXES

LAGER TABLE CLAMPS

HEARINCS COUPL

WORKTABLE

FORKLT

HEATING TIPS

IHSULATING CYLINDERS/OUEH/INSULATIOH
ZIP/PO

94022

94566

94623

74609

7518

11518

66044

94566 


\section{APPENDIX B: DEVELOPMENTAL. MATERIALS/EQUIPMENT}

This Appendix contains summary discussions of the items that are still undergaing product/supplier development. Included in these summaries are a discussion of each item's use, a discussion of the development needed or the existing procurement problem, the status of the development effort, and the AVLIS program contact for the item. 


\section{Develonmental Moterial/Equipment Itern}

Item Titlo: Extractor Pulger for Soparator Module Power Conditioning.

Summary Discussion of Item lise:

The extractor_aulse nawer supply is a bigh voltage, high current, fast switching supply for extracting the photoionized $\underline{U-235}$ ians created in the AVLIS process.

Discussion of Development Needad/Procurement Problem:

The extractor pulse power supply is a state of the art design being developed by an outside vendor. Its ability to meet AVLIS specifications will be verified on the Mars separator. Mars represents $1 / 2$ plant scale, so development will continue to meet plant requirements. The plant prototypic unit can be duplicated by a number of power conditioning vendo:s. 


\section{Devologmental MoteriailEquipmenl tem}

Item Titlo: Graphite Billete for Saparater Moduls Components

Summary Discussion of Item Use:

The separator collector components are fabrlcated from

Stackpole 2020 graphite.

Discussion of Development Needed/Procurement Problem:

Stackpole 2020 is currently availabie oniy in blilet lengths of

72 inches. Billet lengths of 82 inches are available at a onetime cost of $\$ 10,000$. All separator components are designed to be a maximum of 80 inches long. 


\section{Developinental Material/Equigment llem}

Item Title: Machining of Graphite Colloctor Components for the Separator Module

Summary Discussion of item Use:

Many classified componente in the extractor are made from

graphite. These include the arches, roof panels, and product

plates.

Discussion of Development Needad/Pracurement Problem:

There are very few " $O$ " cleared graph te machining_vendors. Currently two commercial vendors are available along with significant in-house capability at Oak Aidge, Hanford, and LLNL. 


\section{Developmentol Material/Equipmenl item}

Item Title: Ceramic Plasma Tubes for Large-Bore CopperVapar Lasers

Summary Discussion of Item Use:

Alumina cylinders o cm in_dlameter ahd 250 to $300 \mathrm{~cm}$ long are used in the coppes-vapor laser head. The cylinders mist be straight and round in cross section to within a few milimeters.

Discussion of Development Needed/Procurement Problem: Present fabrication methods are adequate to produce alumina discharge tubes. However, straighter. rounder tubes yield improved laser performance. Accomplishing this at reduced unit cost has a major impact on operating costs. Approximately 1500 tubes per year will be needed by 1990. 


\section{Developmental Moteriol/Equipment ltem}

Itom Title:_Swltching Power Supply for Large-Bore CopperYopr hatere

Summary Discussion of Item Use:

Pawer supplles are needed to repetitively charge capacitors to oower copper-vapor laser units. Tha power supolies must convert 3-phose, 400 volt power to 10 kvolts de to charge 7 to $15 \mathrm{nF}$ circults et $4.3 \mathrm{kHz}$ and an verage power of $\mathrm{\theta}$ to 15 kwatts.

Discuasion of Development Needed/Procurement Problem:

These power supplies are cuirently being purchased fram three suppliers. In this cate the develogment objective is to increase electrical efficiency and decrease ite nost to below $10.60 \mathrm{mott}$ cost, whlle malntaining a useful life of 50 , 000 hours and a mean time botween failures of 10 ,0BB hours. About 5000 power supplles are needed before 1990. 


\section{Developmental Moleriol/Equipment llem}

Itom Titlo: Copper Containmont for Copper-Vapor Lasers

Summary Discussion of Item Use:

Wick matecial capople of operating at $1500^{\circ} \mathrm{C}$ is neeried to conndense copper onto a wotting surface and return it by

capillary action back into the laser hot zous.

Discussion of Development Needed/Procurement Problem:

At present refractory sylinders are plated in the ends of the laser ceramic tube to wick condensed copper back into the hot zone. While this method works as required and appears to have Iong life, we helieve that a refiactory carbide coating can be sprayed or electro-chemically deposited on the ceramic to perform this function better and at lower cost. 


\section{Develapmental Material/Equipmenl item}

Item Title: Optical Coatings

Summary Discussion of Item Use:

High reflectivity and transmissivity coatings with low absorptance for red to green light is needed for mirrors, wingows, lenses, and polarizors made of crystal quartz, fused silica, saphire, ultra low expansion aptical moterials, and possibly more exotic materials, such as molyhdenum and silicon carbide.

Discussion of Development Needed/Procurement Problem:

At present, adequate coatings are available. However, higher performance coatings can be manufactured and will decrease both the operating and capital costs of the AVLIS laser syetems. It is desired to continue to improve the coating performance coating cost. Approximately 10,000 elements will be neaded by 1390 , with 2,000 to 5,000 needed annually thereofter. 
R. E. Batze1

J. I. Davis

J. L. Emmett

A. C. Haussmann

$L-1$

E. R. Ault

R. D. Dewitt

J. W. Dubrin

T. J. Gilmartin

M. Greer

R. S. Har grove

J. G. Harri

R. E. Hendrickson

J. Z. Holtz

E. I. Moses

R. W. O'Neil

$Y$. Oster

C. Parkin

R. W. Pattersan

J. Preston

R. K. Robinson (5)

M. L. Spaeth

R. i. Tosetti (5)

R. K. White

$L-466$

L-488

L. -28

$\mathrm{L}-463$

$L-372$

$L-467$

$L-467$

$L-438$

$\mathrm{L}-467$

$L-470$

$L-466$

$L-459$

L-462

L-462

$L-440$

L-498

$L-462$

L-50

$L-438$

L-467

$L-439$

$L-46\rangle$

J. I. Davis

CLYA Files (20)

$L-466$

TID (15)

$1-658$ 
Dr. Lester Ettlinger

The MITRE Corporation

METREK Division

1820 Dolley Madison Blvd.

McLean, VA 22102

Dr. James Rushton

Program and Process Planning

Martin Marietta Energy Systems

P. O. Box $P$

Oak Ridge, TN 37831

Mr. Kennet.h Sominerfeld

$V$ ice Pres., Enrichment

Martin Marietta Energy Systems

P. 0. Box $P$

Dak Ridge, TN 37831

Mr. Pichard Dierlam

U.S. Department of Energy

Advanced Technology Projects

Urani um Enrichment, NE-35

Office of Nuclear Energy

Washington, DC 20545

Mr. Don Erb

U.S. Department of Energy

Urani um Enrichment, NE-34

Office of Nuclear Energy

Washington, DC 20545

Process Evaluation Board

$c / 0$ Dr. Kermit Laughon

PEB, Exec. Secretary

U.S. Department of Energy

Office of Nuclear Energy

Wasnington, D.C. 20545

Mr. Joseph H. Parks

U.S. Department of Energy

Oak Ridge Dperations

P. 0. Box E

Oak Ridge, TN 37830

U.S. Deportment of Energy

Technical Informat i in Center.

1. 1i. Buy to?

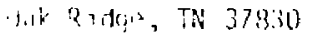

(3)

W. M. Pol ansky

U.S. Department of Energy

Advanced Technology Projects

Uranium Enrichment, NE-35

Oifice of Nuclear Energy

Washington, DC 20545

(3)

J. K. Hancock

(Project File for Congressional Archives)

U.S. Department of Energy

Arvanced Technology Projects

(10) Uranium Enrichment, NE-35

Office of Huclear Energy

Washington, DC 20545

J. R. Longenecker

U.S. Department of Energy

Office of Nuclear Energy

Washington, D.C. 20545

R. T. Ooten

U.S. Department of Energy Oak Ridge Operations Office

P. O. Box E

Oak Ridge, TN 37830

J. Milloway

U.S. Department of Energy

0 ak Ridge Operations office

P. 0. Box E

(7) Oak Ridge, TN 37830

D. F. Craig

M. O. Dixan

C. E. Frye

R. L. Hoglund

A. L. Lotts

J. R. Merriman

G. E. Michaels

J. S. Rayside

T. R. Smith

J. D. Staut

Martin Marietta Energy Systems

$(K-25)$; P. 0. Box P

oak Pidgi, Th ?'B30? 